\title{
STORAGE FACILITIES OF MISSOURI COUNTRY ELEVATORS
}

\section{A Thesis \\ Presented to}

the Faculty of the Graduate School

The University of Missouri

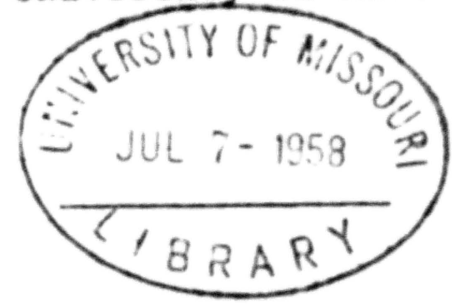

In Partial Fulfillment

of the Requirements for the Degree

Master of Science

by

Francis Preston Yager

June 1958 
The undersigned, appointed by the Dean of the Graduate Faculty, have examined a thesis entitled

\section{STORAGE FACILITIES OF MISSOURI COUNTRY ELEVATORS}

presented by Francis Preston Yager

a candidate for the degree of Master of Science

and hereby certify that in their opinion it is worthy of acceptance.

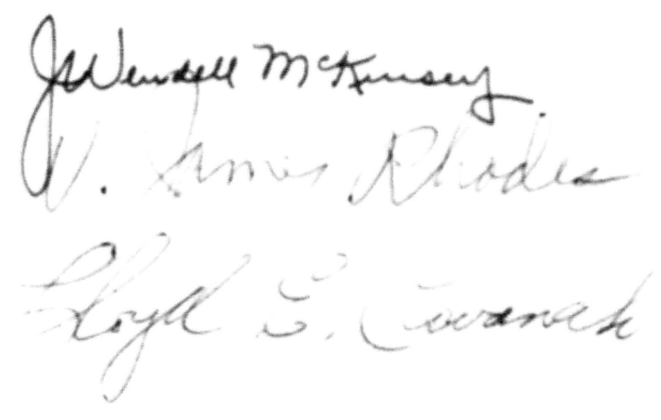




\section{ACKNOWLEDGEMENT}

The writer is grateful to Professors James Wendell McKinsey and David N. Harrington for advice, criticism, and guidance in the development, organization, and writing of the thesis. 
TABLE OF CONTENTS

CHAPTER

PAGE

I. INTRODUCTION . . . . . . . . . . . . . . . . . 1

Role of Grain Production . . . . . . . . . 1

Corn . . . . . . . . . . . . . 4

Grain sorghum . . . . . . . . . . . . 4

Soybeans . . . . . . . . . . . . . . 5

Wheat . . . . . . . . . . . . 6

Barley . . . . . . . . . . . . 6

Oats.................. . . 8

Objectives of the Study . . . . . . . . . 8

Scope and Method of Analysis . . . . . . . 9

Definitions of Terms Used . . . . . . . 13

II. PHYSICAL CHARACTERISTICS OF COUNTRY ELEVATORS. 17

Location of Elevators . . . . . . . . . 17

Type of Ownership . . . . . . . . . . . . 19

Type of Structures of Missouri Elevators • • 21

Concrete tanks. . . . . . . . . . . 21

Steel bins. . . . . . . . . . . . . 22

Wooden bins . . . . . . . . . . . . 23

Facilities . . . . . . . . . . . . . 24

Scales . . . . . . . . . . . . . 24

Grain unloading facilities . . . . . . 26

Leg . . . . . . . . . . . . . . 26

Storage capacity . . . . . . . . . . . . . 29 
v

CHAPTER

PAGE

III. SOURCE OF RECE IPTS OF COUNTRY ELEVATORS . . . 33

Receipts from Farmers . . . . . . . . 33

Receipts from Farmers Relative to Receiving

Facilities . . . . . . . . . . . 37

Volume of Receipts from Farmers Relative to Storage Capacities........... . 40

Receipts from Grain Handlers . . . . . . 42

Relationship of Grain Supplied by Farmers and Grain Handlers . . . . . . . . . . 49

IV. TOTAL HANDLING VOLUME OF COUNTRY ELEVATORS . . 51

Volume of Each Type of Grain that Comprises

Total Handling Volume . . . . . . . . 51

v. STORAGE . . . . . . . . . . . . . . . 57

Turnover in Available Storage Space by Type

Grain for the State ........ . . 57

Utilization of Available Storage Space by

Type Grain for the State . . . . . . . . 59

Turnover in Available Storage Space

Compared with Peak Inventory by Type Grain,

by Crop Reporting District . . . . . . . . 59

Average Inventory Utilization of Available

Storage Space . . . . . . . . . . . 63

VI. SHIPMENTS OF GRAIN ............. . 70

Method of Transportation by Kind of Grain . 70 
CHAPTER

Amounts and Types of Each Grain Shipped for Commodity Credic Corporation and for Storage . . . . . . . . . . . . . 72

Shipments of Grain by Country Elevators as Related to Loading Capacities . . . . . 74 VII. SUMMARY . . . . . . . . . . . . . 77 BIBLIOGRAPHY • • • . . . . . . . . . . . 81 APPENDIX A. Questionnaire Used in Collecting Basic Data............. . 84 APPENDIX B. Tables of Basic Data . . . . . . . . 90 


\section{LIST OF TABLES}

TABLE

PAGE

I. Position of Missouri in Relation to the Leading

States in the Production of Corn, Grain

Sorghum, and Soybeans in the United States

in 1954 and 1956 . . . . . . . . . . . 3

II. Position of Missouri in Relation to the Lead-

ing States in the Production of Wheat,

Barley, and Oats in the United States in

1954 and 1956 . . . . . . . . . . . . . . 7

III. Number of Country Elevators in the Sample and

the Population Within Each Crop Reporting

District, Missouri, 1954 . . . . . . . . 12

IV. Number of Country Elevators in the Sample and

Population Served by One or More Railroads,

or No Railroads, by Crop Reporting District,

Missouri, 1954 . . . . . . . . . . . . 18

v. Country Elevators Classified by Type of

Ownership, Missouri, 1954 . . . . . . . 20

VI. Number of Country Elevators in the Population

by Construction Period by Crop Reporting

District, Missouri, 1954 . . . . . . 25

VII. Number of Country Elevators in the Sample and

Population Having One or More Scales, and

No Scales, by Construction Period, by 
TABLE

Crop Reporting District, Missouri, 1954 . .

VIII. Number of Country Elevators in the Sample and Population Having One or More Dumps, and No Dumps, by Construction Period, by Crop Reporting District, Missouri, 1954 . . .

IX. Number of Country Elevators in the Sample and Population by Rated Leg Capacity and No Legs by Crop Reporting District, Missouri, 1954 .

X. Estimated Total Capacity, Working Space, and Available Storage Space per Country Elevator, by Crop Reporting District, Missouri, 1954 .

XI. Percentage of Total Production Received from Farmers by Type Grain, By Missouri Country Elevators, 1954 . . . . . . . . . . 35

XII. Total Production and Estimated Receipts

Received Direct from Farmers at Country

Elevators, by Type Grain, by Crop Reporting District, Missouri, 1954 . . . . . . 38

XIII. Estimated Total Receipts from Farmers and Receiving Capacity of Missouri Country Elevators by Crop Reporting District, 1954 .

XIV. Estimated Use of Available Storage Space of Country Elevators by Grain, By Crop Reporting District, Missouri, 1954 . . . . 43 
TABLE

XV. Percentage of Total Receipts Received by

Missouri Country Elevators from Grain

Handlers, by Type Grain, 1954 . . . . . . . 45

XVI. Percentage of Receipts from Grain Handlers

Received by Missouri Country Elevators, by

Type Grain, by Type Transportation

Facilities Utilized, 1954 . . . . . . . . 47

XVII. Estimated Total Receipts, by Type Grain from

Grain Handlers, ظy Crop Reporting District, Missouri, 1954 . . . . . . . . . 50

XVIII. Estimated Total Bushels of Grain Handled,

Merchandised, Shipped for Storage, and

Commodity Credit Corporation, by Type Grain,

Missouri Country Elevators, 1954 . . . . 55

XIX. Number of Times Turnover in Available Storage

Space for Country Elevators to Handle Total

Production, by Grain, Missouri, 1954 . . . 58

XX. Per Cent of Total Available Storage Space

Utilized During Peak Inventory, by Type

Grain, Missouri, 1954 . . . . . . . . 60

XXI. Number of Times Turnover in Available Storage

Space for Grain Handled by the Country

Elevators, by Type Grain, by Crop Reporting

District, Missouri, 1954 . . . . . . . 64 
TABLE

XXII. Per Cent of Total Available Storage Space Utilized by Country Elevators During Peak Inventory, by Crop Repurting District, by Type Grain, Missouri, 1954 . . . . . . . 65

XXIII. Per Cent Utilization of Available Storage Space of Country Elevators, by Crop Reporting District, Missouri, 1954 . . . . . . 69 XXIV. Estimated Percentage of Total Grain Handled by Missouri Country Elevators That Was Shipped Outside the Trade Territory by Bushels and Percentage Shipped by Type Carrier, by Type Grain, 1954 . . . . . . 73

XXV. Estimated Total Shipments from Country Elevators and Loading Capacities by Crop Reporting District, Missouri, 1954 . . . 76 


\section{LIST OF APPENDIX TABLES}

TABLE

PAGE

XXVI. Estimated Receipts of Wheat and Soybeans at Country Elevators, by Crop Reporting District, Missouri, 1954 . . . . . . 91

XXVII. Estimated Receipts of Corn at Country Elevators, by Crop Reporting District, Missouri, 1954 . . . . . . . . . . 92

XXVIII. Estimated Receipts of Oats at Country

Elevators, by Crop Reporting District, Missouri, 1954 . . . . . . . . .

XXIX. Estimated Receipts of Barley at Country

Elevators, by Crop Reporting District, Missouri, 1954 . . . . . . . . . . . 94

XXX. Estimated Receipts of Grain Sorghum at

Country Elevators, by Crop Reporting

District, Missouri, 1954 . . . . . . 95

XXXI. Estimated Volume of Wheat Handled at

Country Elevators, by Crop Reporting

District, Missouri, 1954 . . . . . . 96

XXXII. Estimated Volume of Soybeans Handled at

Country Elevators, by Crop Reporting

District, Missouri, 1954 . . . . . . 97

XXXIII. Estimated Volume of Corn Handled at 
TABLE

Country Elevators, by Crop Reporting District, Missouri, 1954 . . . . .

XXIV. Estimated Volume of Oats Handled at Country Elevators, by Crop Reporting District, Missouri, 1954 . • • . . . . . • •

XXXV. Estimated Volume of Barley Handled at

Country Elevators, by Crop Reporting District, Missouri, 1954 . . . . . . 100

XXXVI. Estimated Volume of Grain Sorghum Handled at Country Elevators, by Crop Reporting District, Missouri, 1954 . . . . . . 101

XXXVII. Estimated Peak Storage Inventory of Wheat and Corn at Country Elevators, by Crop Reporting District, Missouri, 1954 . • 102 XXXVIII. Estimated Peak Storage Inventory of

Soybeans at Country Elevators, by Crop Reporting District, Missouri, 1954 . . 103

XXXIX. Estimated Peak Storage Inventory of Oats, Barley, and Grain Sorghum at Country Elevators, by Crop Reporting District, Missouri, 1954 . . . . . . . . 104 XL. Estimated Average Storage Inventory of Corn and Wheat at Country Elevators, by Crop Reporting District, Missouri, 1954 . 105 


\section{xiil}

TABLE

PAGE

XLI. Estimated Average Storage Inventory of Soybeans at Country Elevators, by Crop Reporting District, Missouri, 1954 . .

XLII. Estimated Average Storage Inventory of Oats, Barley, and Grain Sorghum at Country Elevators, by Crop Reporting District, Missouri, 1954 . . . . . . . . .

XLIII. Estimated Shipment of Wheat from Country

Elevators to All Markets, by Type Carrier, by Crop Reporting District, Missouri, 1954 . . . . . . . •

XLIV. Estimated Shipment of Soybeans from

Country Elevators to All Markets, by Type Carrier, by Crop Reporting District, Missouri, 1954 . . . . . . . . .

XLV. Estimated Shipments of Corn from Country

Elevators to All Markets, by Type Carrier,

by Crop Reporting District, Missouri, 1954 . . . . . . . . . . 110

XLVI. Estimated Shipments of Oats from Country

Elevators to All Markets, by Type Carrier, by Crop Reporting District, Missouri, 1954

XLVII. Estimated Shipment of Barley and Grain 
TABLE

xiv

PAGE

Sorghum from Country Elevators to All

Markets, by Type Carrier, by Crop

Reporting District, Missouri, 1954 . . 112 


\section{LIST OF FIGURES}

F IGURE

1. Location of Crop Reporting Districts, Missouri, 1954 . . . . . . . . . . . . . . 10

2. Country Elevators Included in the Sample, Missouri, 1954 . . . . . . . . . . . . . 14

3. Distribution of the Total Grain Handled, Sold Locally, Sold Outside, Shipped for CCC, and Storage by Country Elevators, Missouri, 1954 . . . . . . . . . . . . . . 52 


\section{CHAPTER I}

\section{INTRODUCT ION}

The country elevator ${ }^{1}$ performs the first step in the marketing channel for grain. In Missouri, the principal function of country elevators is that of buying and concentration. Here the farmer finds a ready cash grain market throughout the year. In addition, some country elevators store grain for farmers and processors or grain owned by the elevator itself. Many elevators, in addition to these services, mix feed, grind, shell corn, sell fertilizer and other farm supplies. Missouri farmers are served by approximately 546 country grain elevators.

\section{ROLE OF GRAIN PRODUCTION}

The competition for elevator storage of the grains studied varied by regions and among crops because of variations in relative importance to the different Crop Reporting Districts. ${ }^{2}$ In 1954 approximately 71 per cent

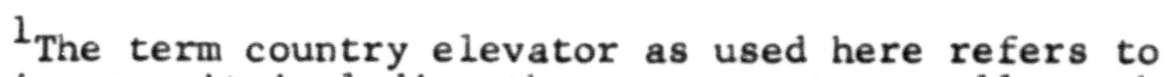
the business unit including the management as well as the physical facilities. If the term is used to mean either to the exclusion of the other, the context will make the meaning clear.

${ }^{2}$ See Figure 1, page 10 for location of Crop Reporting Districts. 
of the total crop land in Missouri was devoted to the production of grain crops. Approximately $97,402,000$ bushels of corn, grain sorghum, soybeans, wheat, barley, and oats, valued at $\$ 180 \mathrm{million}$, wen handled by Missouri country grain elevators.

The total production of corn, soybeans, grain sorghum, wheat, oats, and barley for Missouri in 1954 was $204,754,000$ bushels. ${ }^{3}$

Production by grains varied from a high of $69,201,000$ bushels of corn to a low of $1,056,000$ bushels for grain sorghum. Oats ranked second in production with $59,843,000$ bushels followed by wheat with $40,114,000$ bushels. Soybeans was fourth with $27,540,000$ bushels and next to last was barley with $7,00 \mathrm{c}, 000$ bushels.

In analyzing storage problems corn, grain sorghum, and soybeans were considered together because they compete for storage facilities during the harvesting period. In 1954 Missouri farmers produced $97,797,000$ bushels of corn, grain sorghum, and soybeans as compared to $234,138,000$ bushels in 1956. Missouri ranked tenth in the production of corn, grain sorghum, and soybeans in the United States in 1954 and sixth in production in 1956 (Table I). This

${ }^{3}$ Missouri Farm Census by Counties 1954, (Missouri Crop Report. Jefferson City: Missouri State Department of Agriculture, 1954), pp. 10-16. 
TABLE I

POSITION OF MISSOURI IN RELATION TO THE LEADING STATES IN

THE PRODUCTION OF CORN, GRAIN SORGHUM, AND SOYBEANS

IN THE UNITED STATES IN 1954 AND 1956

\begin{tabular}{|c|c|c|c|c|}
\hline \multirow[b]{2}{*}{ State } & \multicolumn{2}{|c|}{$1954 * \star$} & \multicolumn{2}{|c|}{$1956 * \star * \star$} \\
\hline & $\begin{array}{l}\text { Total } \\
\text { Production* }\end{array}$ & Rank & $\begin{array}{l}\text { Total } \\
\text { Production* }\end{array}$ & Rank \\
\hline Iowa & 595,915 & 1 & 575,819 & 2 \\
\hline Illinois & 541,526 & 2 & 733,620 & 1 \\
\hline Minnesota & 319,337 & 3 & 382,245 & 3 \\
\hline Indi ana & 302,352 & 4 & 348,754 & 4 \\
\hline Ohio & 261,774 & 5 & 246,924 & 5 \\
\hline Nebraska & 213,596 & 6 & 131,058 & 9 \\
\hline Wisconsin & 155,480 & 7 & 168,458 & 7 \\
\hline Texas & 150,655 & 8 & 152,067 & 8 \\
\hline South Dakota & 119,937 & 9 & 110,109 & 10 \\
\hline Missouri & 97,797 & 10 & 234,138 & 6 \\
\hline Kansas & 87,044 & 11 & 59,475 & 12 \\
\hline Kentucky & 68,481 & 12 & 87,673 & 11 \\
\hline United States & $3,511,521$ & & $4,112,226$ & \\
\hline
\end{tabular}

*In thousands of bushels.

**"United States Crop Summary as of August 1, 1955," Crop

Production, United States Department of Agriculture, Agricultural Marketing Service, August 10, 1955, pp. 30-37.

***"United States Crop Summary as of August 1, 1957," Crop Production, United States Department of Agriculture, Agricultural Marketing Service, August 9, 1957, pp. 35-41. 
change in position resulted primarily from Missouri weather conditions.

$\underline{\text { Corn }}$

The twenty-two counties producing more than one million bushels of corn in 1954 accounted for 49.73 per cent of the corn produced in Missouri. The Crop Reporting Districts 1 through 5 , and 9 in which these counties are located produced 90.96 per cent of the corn in the state. Areas of heaviest corn production are located primarily in north, west, and southeast Missouri.

Corn harvest in Missouri starts during the month of October and continues into the month of December. The harvesting time of corn has been reduced since the introduction of the picker sheller. This has created a problem of storage both on the farm and off. The need for storage space by Commodity Credit Corporation, farmers, and processors has increased the need for more storage space at the country elevators.

Grain Sorghum

In 1954 grain sorghum was just beginning to assume importance in the state. The ledding Crop Reporting Districts 2 and 4 produced over 64 per cent of the grain sorghum in the state that year.

Grain sorghum harvest begins in October in Missouri. 
The production of this crop is well adapted to a dry climate. Because of the humid climate in Missouri, drying the grain to 12 per cent moisture for safe storage constitutes a problem. Acreage of grain sorghum has increased since 1954, because there has been no acreage allotment, and because of the drought conditions which have existed in Missouri.

\section{Soybeans}

The two major areas producing 59.43 per cent of the soybeans in Missouri are Crop Reporting Districts 3 and 9. They are located in the northeast and southeast corners of the state, respectivaly. The leading counties in production within those districts are Clark in District 3 , and Dunklin, New Madrid, Pemiscot, and Stoddard in District 9. Those five counties produced over 30 per cent of Missouri's supply of soybeans in 1954 .

Soybean harvest starts the last part of August for the early varieties and continues into October for the later-maturing ones. The soybean is an important crop from several standpoints. The soybean is a cash crop, it has no acreage allotment to date, lends itself to mechanized harvesting, and it is well adapted to the various soil types of Missouri.

Wheat, barley, and oats compete for storage during 
the months of June, July, and August in Missouri, for these are tife months of harvest. In 1954, approximately $106,957,000$ bushels of wheat, barley, and oats were harvested in Missouri. This was a record or near record production year for Missouri. The drought condition did not prevail until after the harvesting of those grains. Missouri ranked tenth in the total production of wheat, barley, and oats in 1954 as compared to seventh in 1956 (Table II). Important factors in the ranking of Missouri with other states are the weather conditions, new crops, new varieties, and irrigation.

Wheat

The counties producing more than one million bushels of wheat in 1954 were Carroll in District 2, Bates and Vernon in District 4, St. Charles in District 6, Barton and Jasper in District 7. Those six counties produced 17.06 per cent of the wheat produced in the state. The counties located within Crop Reporting Districts 2, 4,6 , and 7 produced 48.86 per cent of the wheat in the state. The areas of heaviest wheat production lie along the Missouri and Mississippi Rivers and in those counties along the southwestern edge of Missouri.

Barley

The leading areas of barley production are in the 


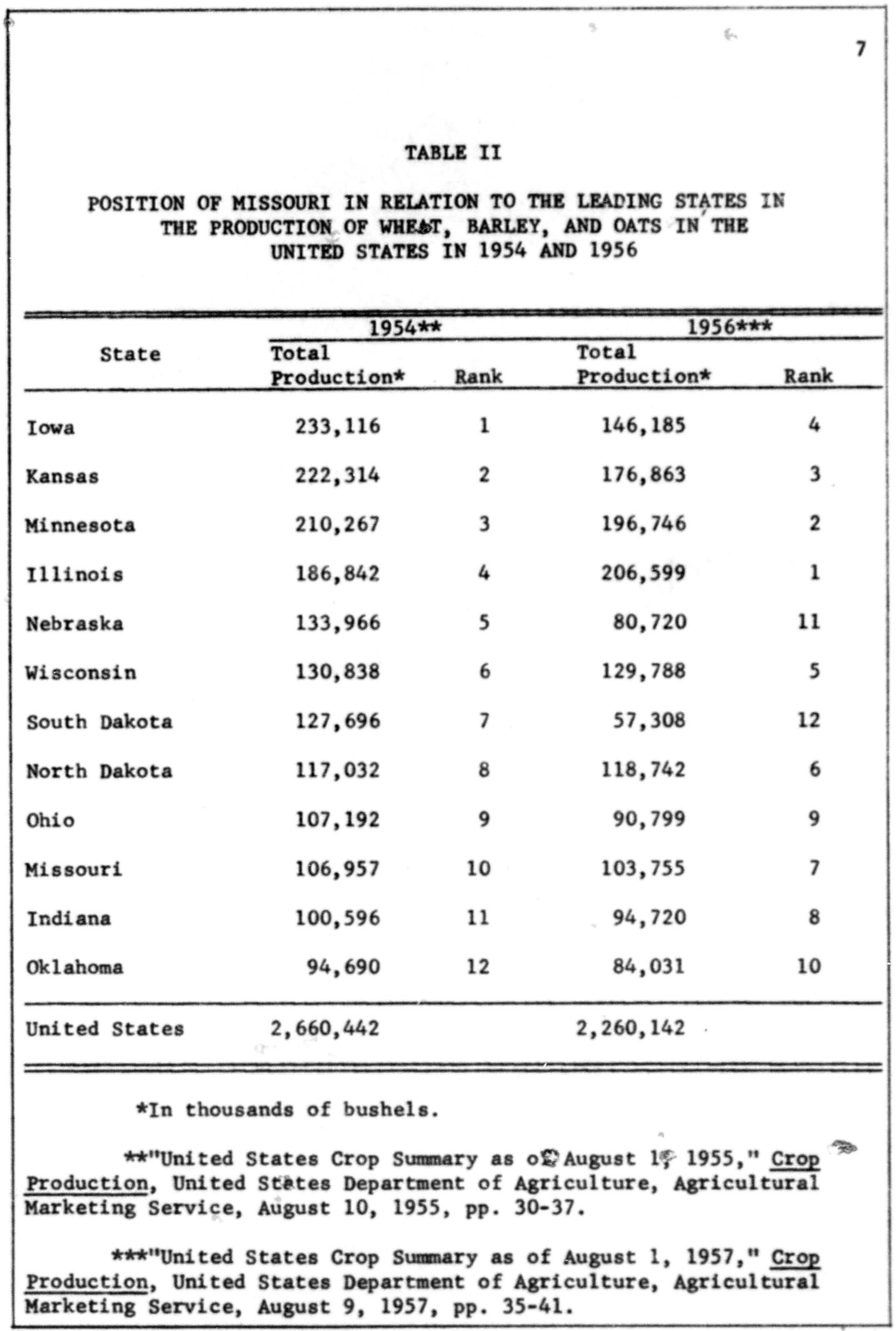


central and southwestern portion of the state. The Crop Reporting Districts located within that area are 4, 5, and 7. Those Crop Repcrting Districts produce 73.83 per ent of all the barley grown in the state. An important reason for the production of barley in that area can be attributed to the less severe winters.

\section{$\underline{\text { Oats }}$}

The production of Missouri oats was fairly well concentrated in 1954. Crop Reporting Districts 1, 4, 5, and 7 produced 66.79 per cent of the total production. There were sixteen counties within those districts that produced 34.81 per cent of the state's total supply. The areas of greacest oat production are in the central part and along the western edge of Missouri.

\section{OBJECTIVES OF THE STUDY}

The objectives are to determine adequacy of present storage facilities by Crop Reporting Districts and to provide information for decisions relative to location, capacity, type, remodeling, and rebuilding of country elevator storage facilities in conjunction with the present trends in marketing techniques.

The data collected pertain to the nine Crop Reporting Districts of the state and the country elevators 
within those districts. See Figure 1 for the location of the nine districts.

Decisions relative to location, capacity, type of new storage, and marketing facilities are being made currently and likely will continue to be made over the next ten years. Those decisions are being made by farmers, cooperative associations, businessmen, and government agencies with only a small amount of factual data available.

\section{SCOPE AND METHOD OF ANALYSIS}

This study is a part of a cooperative project of the North Central States ${ }^{4}$ on the "Economic Problems of Grain Marketing and Grain Storage at Country Elevators, (NCM-10-B-2)."

The schedules ${ }^{5}$ were taken by personal interview during the summer of 1955. The information obtained was over the last full year's operation which was 1954. In most cases the managers of the country elevators were interviewed. In some cases it was not possible to get the information from the manager but it was obtained from an

${ }^{4}$ Illinois, Indiana, Iowa, Kansas, Michigan, Minnesota, Missouri, Nebraska, North Dakota, Ohio, South Dakota, and Wisconsin. ${ }^{5}$ The schedule used in this study is shown in
Appendix A. 
5

?

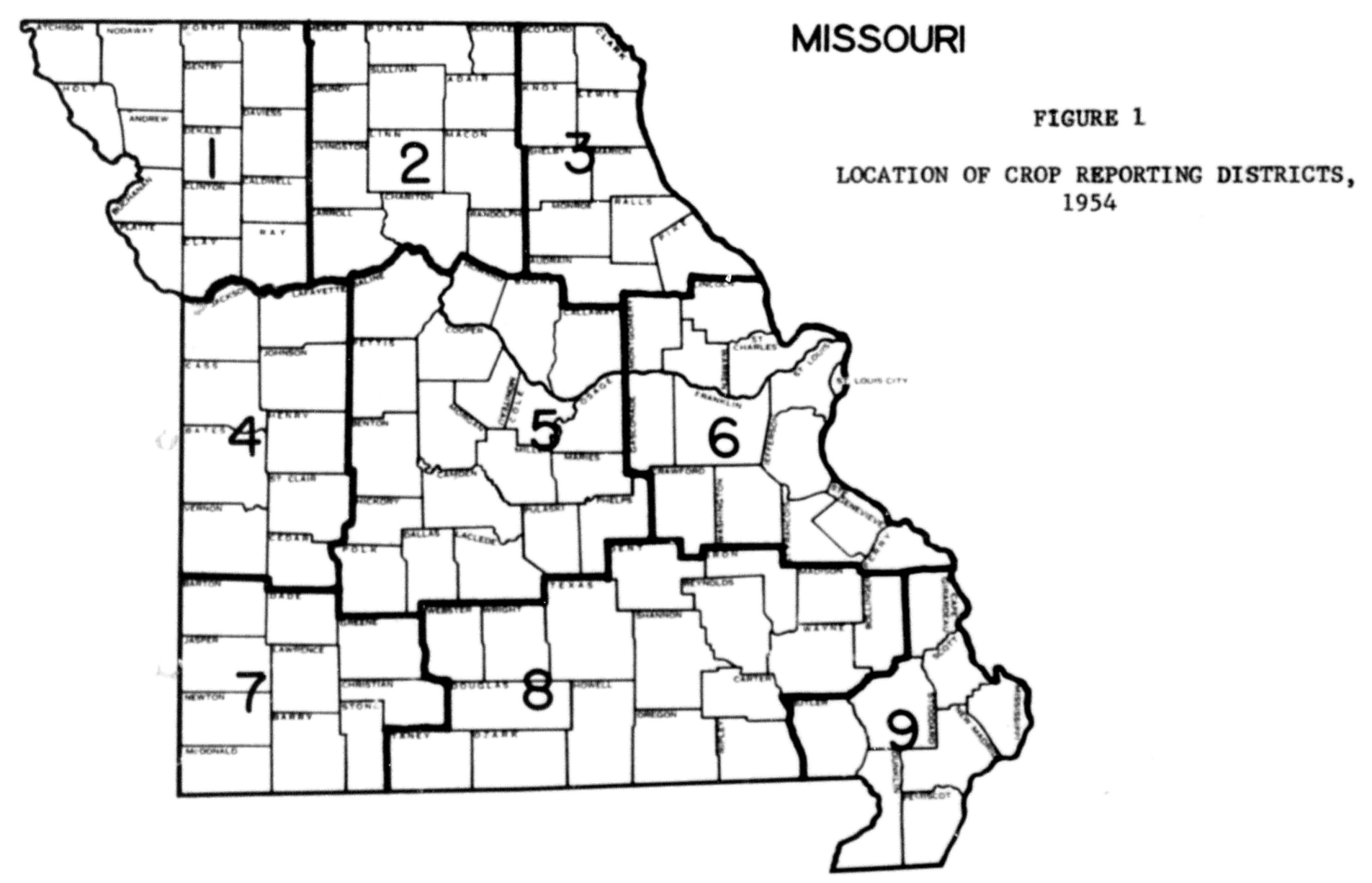

$\circ$ 
employee of the elevator.

The population of country elevators was established frop trade association directories, federal and state licensed warehouse lists, information from local and state agencies of the Department of Agriculture, and from personal consultation with people in the grain trade. There were 546 country elevators in the population. The sample included 105 of those elevators (Table III).

The country elevator population in Missouri was stratified by Crop Reporting Districts. The country elevators in each Crop Reporting District were selected at random. Every elevator in the district had an equal chance of falling into the sample. In drawing the sample it made no difference whether the elevator was large or small, cooperative, line, independent, branch, concrete, steel, wood, or with or without a licensed storage capacity.

The sample was selected by arraying all of the country elevators in each Crop Reporting District alphabetically by town, and then each elevator within each district was numbered consecutively.

The original sampling plan was to use a 10 per cent sample with the restriction that the sample would include a minimum of ten elevators per Crop Reporting District. The list from which the sample was drawn indicated 


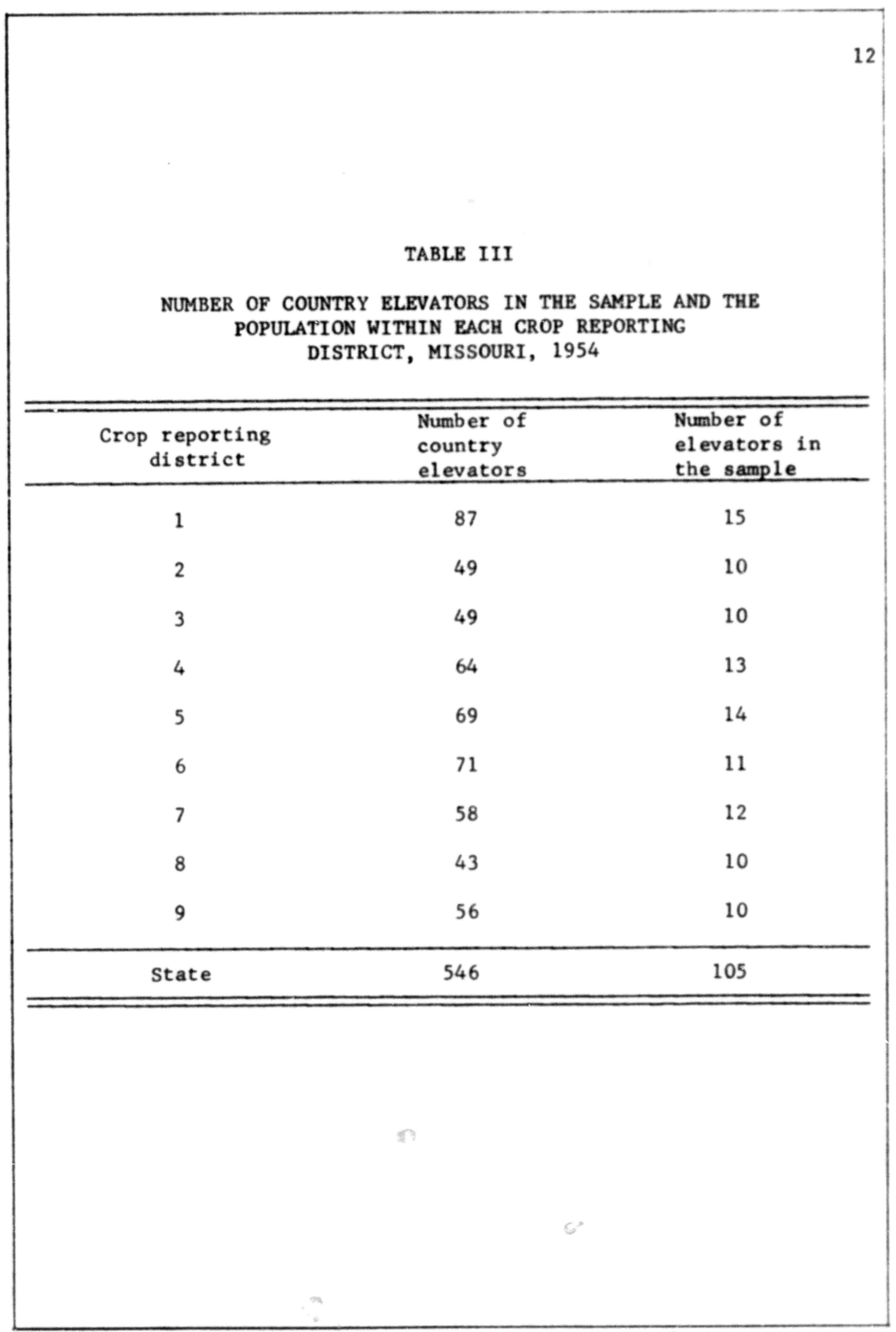


approximately one hundred country elevators in each crop reporting district. However, upon interviewing the operators, it was found that many of the elevators in the sample did not fit the definition of a country elevator as used in this study. Consequently, the list of country elevators as well as the sample was revised and all of the information obtained was used in establishing the sample and population. For the distribution of country elevators in the sample by Crop Reporting Districts see Figure 2. If a schedule could not be obtained from a particular elevator, an alternate was selected by the same procedure used in obtaining the original sample.

The mean estimator was used to expand the sample size. The mean estimator is simply the ratio of the number of country elevators in the population to the number of elevators in the sample in a particular Crop Reporting District times the total sample value of the data to be estimated for that Crop Reporting District.

\section{DEFINITIONS OF TERMS USED}

Country Elevators--for the purpose of this study country elevators include all grain merchandising elevators with an annual grain handling volume of at least 10,000 bushels of raw grain of which over 50 per cent was received from farmers direct. The 


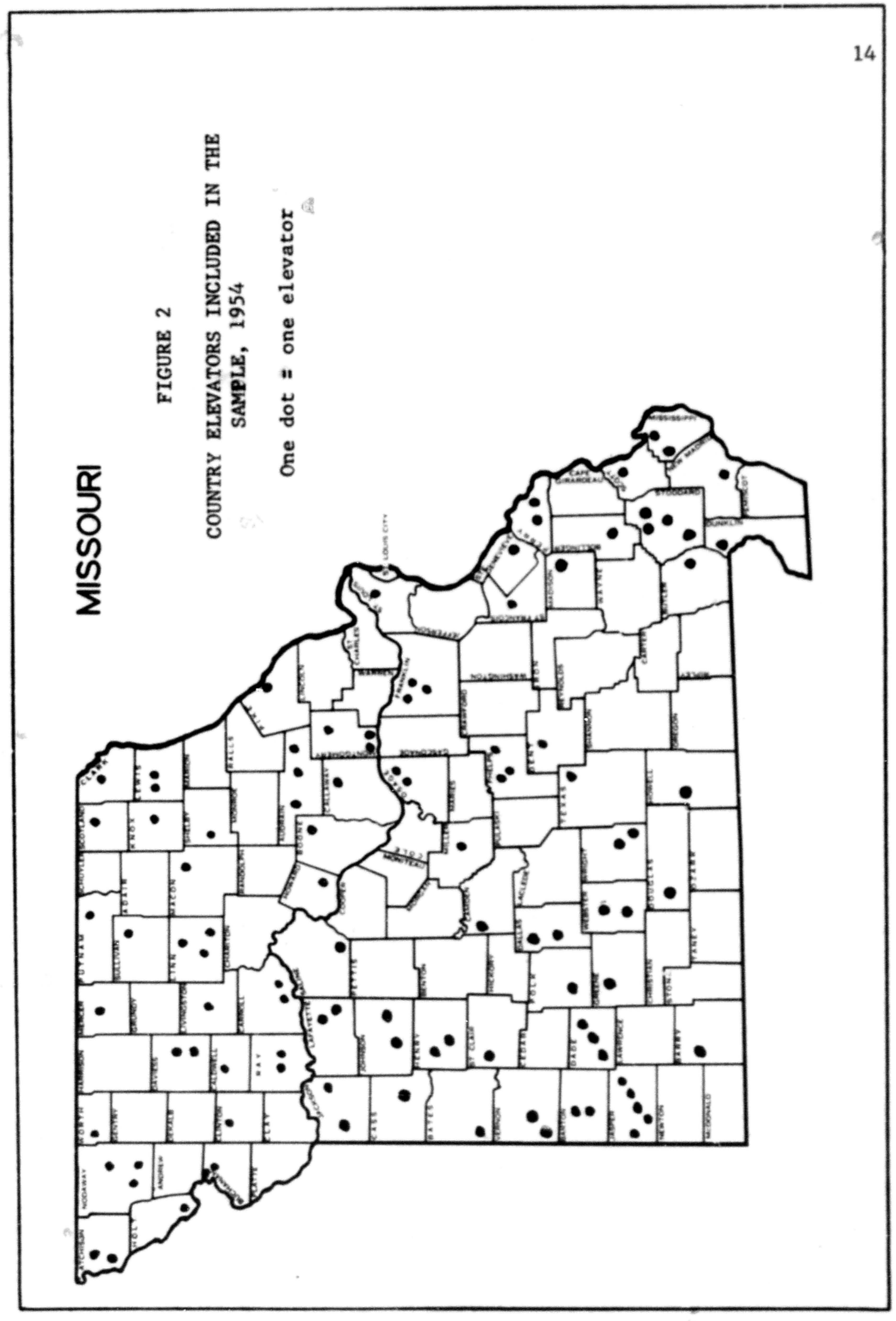


elevator had to sell at least 50 per cent of the grain as raw grain as opposed to grain products or prepared mixed feed.

Blending--blending of grain is the mixing of two or more grades of grain intended to produce a uniform grade of grain higher than one of the original grades. Dump--is a pit constructed of concrete or wood and covered with a grate appropriate to the grain being received. It is located beneath the driveway and connected to the elevator by a mechanical drag. Grain processing--changing the form of grain by grinding, mixing, pressing, or otherwise changing the grain from raw grain to another form.

Elevator leg--an auger, blower, or endless belt used to elevate grain in order that it may be stored or loaded onto vehicles for transportation.

Feed grains--corn, oats, barley, and grain sorghum.

Cash grains--wheat and soybeans.

Storage--a bin, tank, or crib used for the purpose of holding or storing grain until the time it is sold or disposal is made.

Population--is used to denote the aggregate from which the sample is chosen.

Handling volume--total of the quantity of grain merchandised, the quantity of grain shipped from 
the elevator for storage at some other storage facility, and the quantity of grain shipped fpr Commodity Credit Corporation.

Working space--refers to that part of the total capacity

of a country elevator required for such activities

as the turning or blending of bulk grain.

Available storage space--is that capacity of a country

elevator which represents the total capacity less the requirements for working space.

Merchandising--may be defined in this study as the buying and selling of grain.

Scalp grain--the process of removing major foreign material from grain. 


\section{CHAPTER II}

\section{PHYSICAL CHARACTER ISTICS OF COUNTRY ELEVATORS}

Approximately 45 per cent of the country elevators in Missouri were built prior to 1935. The development of trucks and improved roads since that time has induced considerable change in grain marketing at the country level. In the past decade there has been considerable reorganization of the physical facilities of country elevators to accommodate trucks, both in receiving and shipping grain.

\section{LOCATION OF ELEVATORS}

Missouri had 453 country elevators located on railroads in 1954. The remaining 93 elevators not on railroads hauled grain several miles to railroads or transported the grain to terminal markets or processors by truck (Table IV).

Truck transportation has certain advantages in the shipment of grain, especially that moved only a short distance. The mobility of trucks over improved roads gives country elevators additional alternative markets and allows a flexible shipping schedule. 


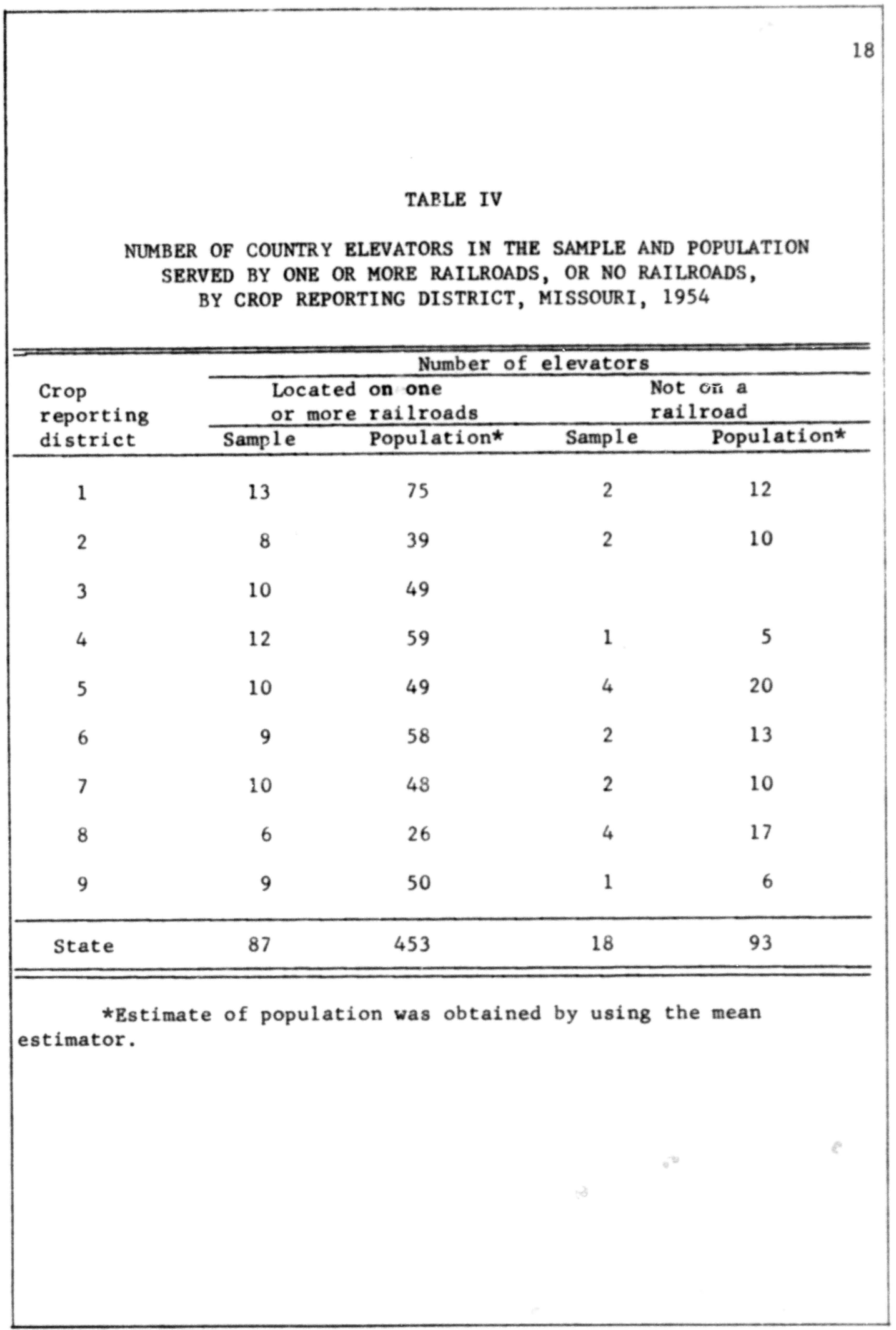




\section{TYPE OF OWNERSHIP}

The country elevators in this study were classified

as follows: (1) cooperatives, those elevators which were operated by farmers as independent cooperatives; independent, those elevators owned and operated by individual grain men who provided their own capital and usually operated the elevators themselves; (3) independent branch, those elevators operated by individuals as a subsidiary of another independent elevator; (4) cooperative branch, those elevators operated as a subsidiary of another cooperative elevator; and (5) independent line refers to a country elevator which is one of a series of country elevators operated by a terminal elevator or processor or by a company which also operates a terminal elevator or processing plant.

Over 50 per cent of the country elevators in Missouri are owned by individuals. Less than one third are cooperatives. An additional 7.69 per cent of the country elevators are cooperative branches, and 4.76 per cent are independent branches. The independent line elevators operating in Missouri make up approximately 10 per cent of the total number of elevators in the state (Table V).

It is difficult to interpret the degree of 


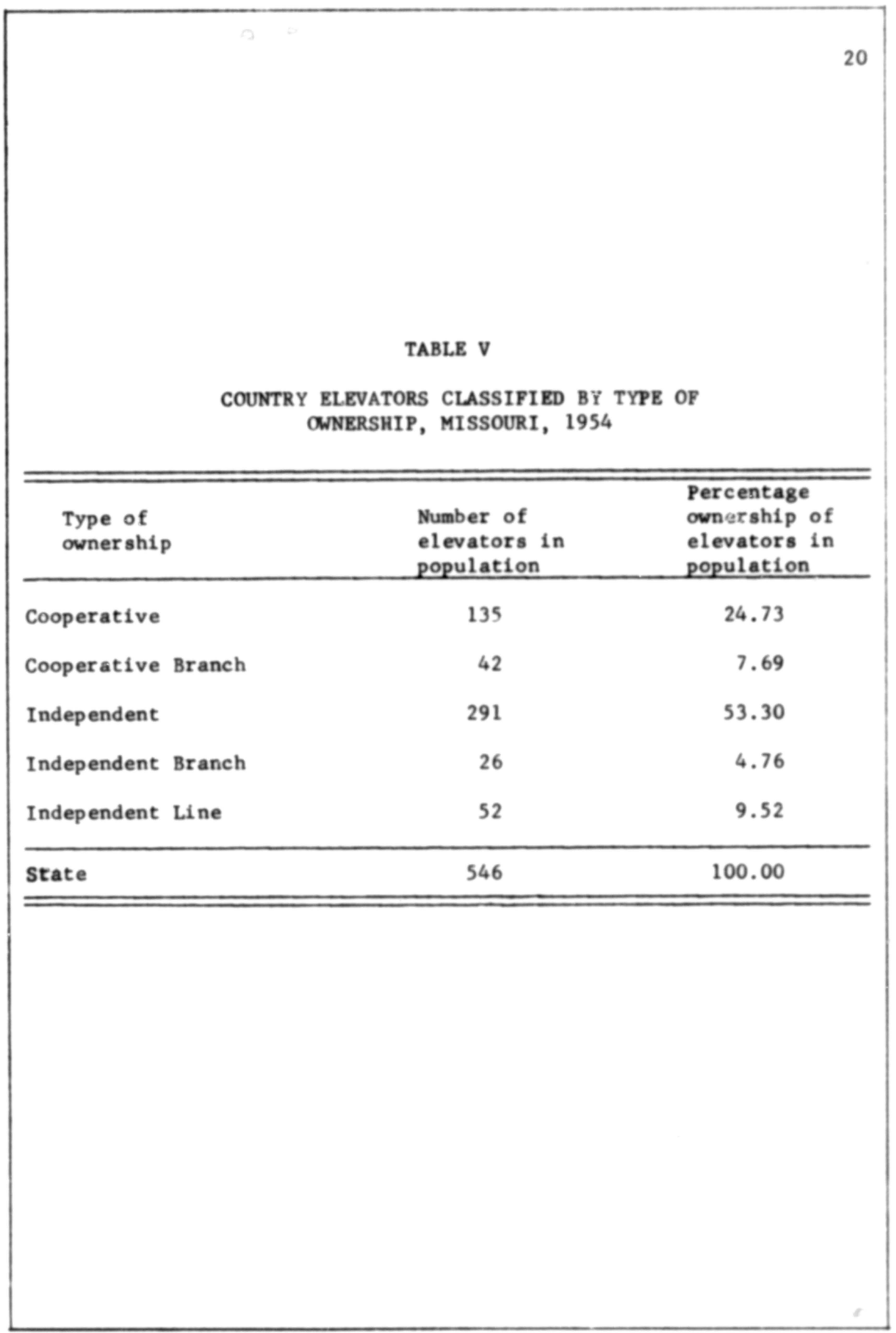


integration which exists in Missouri grain elevators. The elevators designated as independent branches and cooperative granches may be horizontally integrated in the sense that they are one of several elevators operated by a home office at the same level in the grain marketing system. They may be vertically integrated with other country elevators which the home office operates at various levels of the marketing structure. Thus, a country elevator may be one of several grain elevators operated by a home office in several different levels of markets.

\section{TYPE OF STRUCTURES OF MISSOURI ELEVATORS}

The grain 3torage structures at country elevators in Missouri are: (1) concrete tanks; (2) steel tanks; or (3) wooden bins. It is estimated from this study that approximately 297 country elevators used wooden structures, eighty-five used steel, sixty-six used concrete, and ninety-eight country elevators used a combination. Each of these structures have distinct advantages and disadvantages.

Concrete Tanks

These structures are well adapted to storing large amounts of grain in bulk. They are made of a network of stee 1 rods embedded in concrete 6 to 7 inches thick. In 
order to avoid grinding and breakage of the grains the walls should be smooth on the inside, which in turn will help prevent dust explosions. Concrete tanks have the following advantages: ${ }^{1}$ (1) Very impervious to weather, fire, or vermin; (2) they may be built in any size and shape; (3) they do not sweat; (4) they resist lateral pressures of bulk grain well; and (5) they are economical to construct for large storage capacities.

The disadvantages ${ }^{2}$ of concrete structures are that they have a high initial cust and are not suitable for storage of damp grains because changes in the temperature of the atmosphere are transmitted slowly through the walls. Steel Bins

These bins are usually made in the form of a cylinder. The only protective covering is the equipment used in filling and loading of grain. Steel bins have the following advantages. ${ }^{3}$ (1) Rapid and easy to erect; (2) fireproof; (3) vermin-proof; (4) comparatively low cost; and (5) they are relatively strong provided scaling does

$1_{\text {The Consolidated Grain Milling Catalogs (fifth }}$ edition; Chreago: American Miller, Copyright, National Miller Publications, Inc., 1941), p. 320.

2 Ibid.

3 Ibid. 
not occur.

Bins made of steel have these disadvantages: ${ }^{4}$

In humid climates such as Missouri's they have a tendency to sweat with the moisture collecting on the inside of the roof; (2) this excess moisture drops onto the grain causing it to sprout, spoil, and become musty; and (3) there is danger of buckling under changing stresses and strains, unless thick plates of steel are perfectly welded or riveted.

Wooden Bins

Wooden bins have the following advantages: ${ }^{5}$

They do not sweat and, therefore, are well adapted to the storage of damp and out-of-condition grain; and (2) they are vermin-proof, if they are clean on the inside and the timbers are well seasoned.

Bins made of wood are subject to several criticisms: (1) They are not fireproof; (2) they are difficult to repair; (3) they are not as durable as concrete and steel; and (4) they shrink and may warp out of true.

A large portion of the 244 country elevators constructed prior to 1936 were wooden. Some of those

4

${ }^{4}$ Ibid.

${ }^{5}$ Ibid.

${ }^{6}$ Ibid. 
elevators were later covered with corrugated metal for protection against weather and fire. During this period very few concrete elevators were built because of the high initial cost. During the period of 1936-1955 a shift toward concrete and steel in elevator construction took place. During this time there were 302 elevators constructed in the various Crop Reporting Districts throughout the state (Table VI).

\section{FACILITIES}

The kind and amount of facilities incorporated into the country elevator plant is to a considerable degree the determinant of the kind and amount of services which the elevator can offer its customers. There is considerable variation among the 546 elevators in Missouri in this respect. Marketing trends of the past two decades have exerted a strong influence for adding new facilities, both in the building of new plants and in the remodeling of old. However, many country elevators still lack adequate physical facilities within their plant to receive, store, and dispose of the grain they purchase.

Scales

Scales are used to weigh incoming and outgoing vehicles loaded with grain for sale and purchase by the 


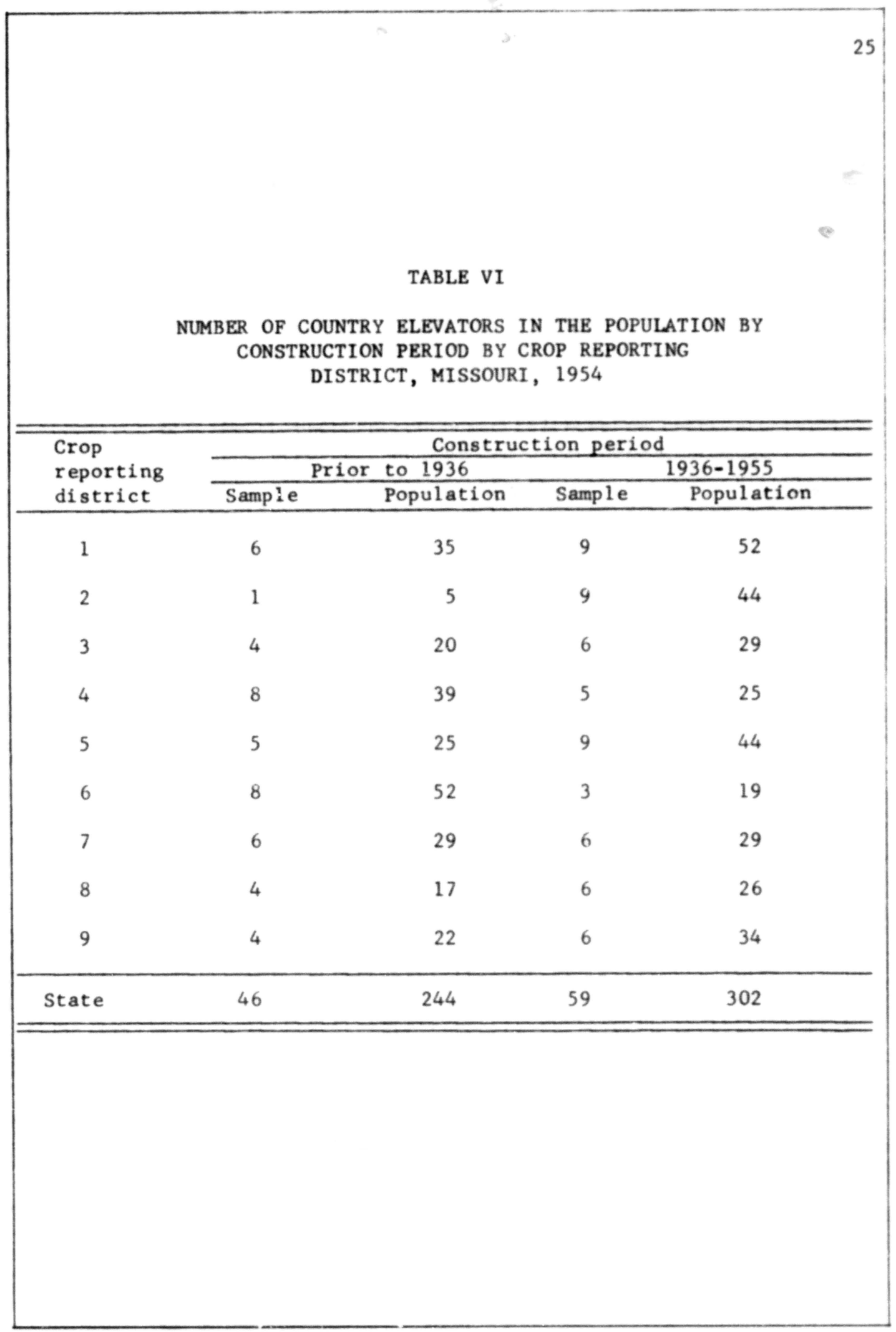


country elevator and its customers. Country elevator scales should be large enough to accommodate the vehicles in the trade area used to transport the surplus grain to market. The scales should be so arranged as to allow trucks and tractors to go onto and off the scales without making short turns or encountering steep grades. There were 422 elevators in the state that had weighing facilities, as compared to 124 that depended upon public scales for weighing the grain they received and shipped. There were 74 country elevator scales constructed prior to 1936. Since 1936 there were 348 scales constructed (Table VII). Even though a greater number of scales was constructed during that period some are still unable to accommodate the present trends in our transportation system.

Grain Unloading Facilities

Approximately 106 country elevators in the population did not have a grain dump in 1954. The grain received by those elevators had to be shoveled by hand from the trucks and wagons. This study reflects that 440 elevators had dumps, and of this number 120 were constructed prior to 1936 (Table VIII).

$\underline{\text { Leg }}$

The elevator legs in Missouri are constructed of 
TABLE VII

NUMBER OF COUNTRY ELEVATORS IN THE SAMPLE AND POPULATION HAVING ONE OR MORE SCALES, AND NO SCALES, BY CONSTRUCTION PERIOD, BY CROP REPORTING DISTRICT, MISSOURI, 1954

\begin{tabular}{|c|c|c|c|c|c|c|}
\hline \multirow{3}{*}{$\begin{array}{l}\text { Crop } \\
\text { reporting } \\
\text { district }\end{array}$} & \multicolumn{4}{|c|}{ Construction period } & \multirow{2}{*}{\multicolumn{2}{|c|}{$\begin{array}{c}\text { Elevators } \\
\text { without scales }\end{array}$}} \\
\hline & \multicolumn{3}{|c|}{ Prior to 1936} & $1936-1955$ & & \\
\hline & Sample & Population & Sample & Population & Sample & Population \\
\hline 1 & 1 & 6 & 13 & 75 & 1 & 6 \\
\hline 2 & & & 8 & 39 & 2 & 10 \\
\hline 3 & 1 & 5 & 8 & 39 & 1 & 5 \\
\hline 4 & 2 & 10 & 9 & 44 & 2 & 10 \\
\hline 5 & 4 & 19 & 5 & 25 & 5 & 25 \\
\hline 6 & 2 & 13 & 7 & 45 & 2 & 13 \\
\hline 7 & 2 & 10 & 8 & 38 & 2 & 10 \\
\hline 8 & & & 1 & 4 & 9 & 39 \\
\hline 9 & 2 & 11 & 7 & 39 & 1 & 6 \\
\hline State & 14 & 74 & 66 & 348 & 25 & 124 \\
\hline
\end{tabular}




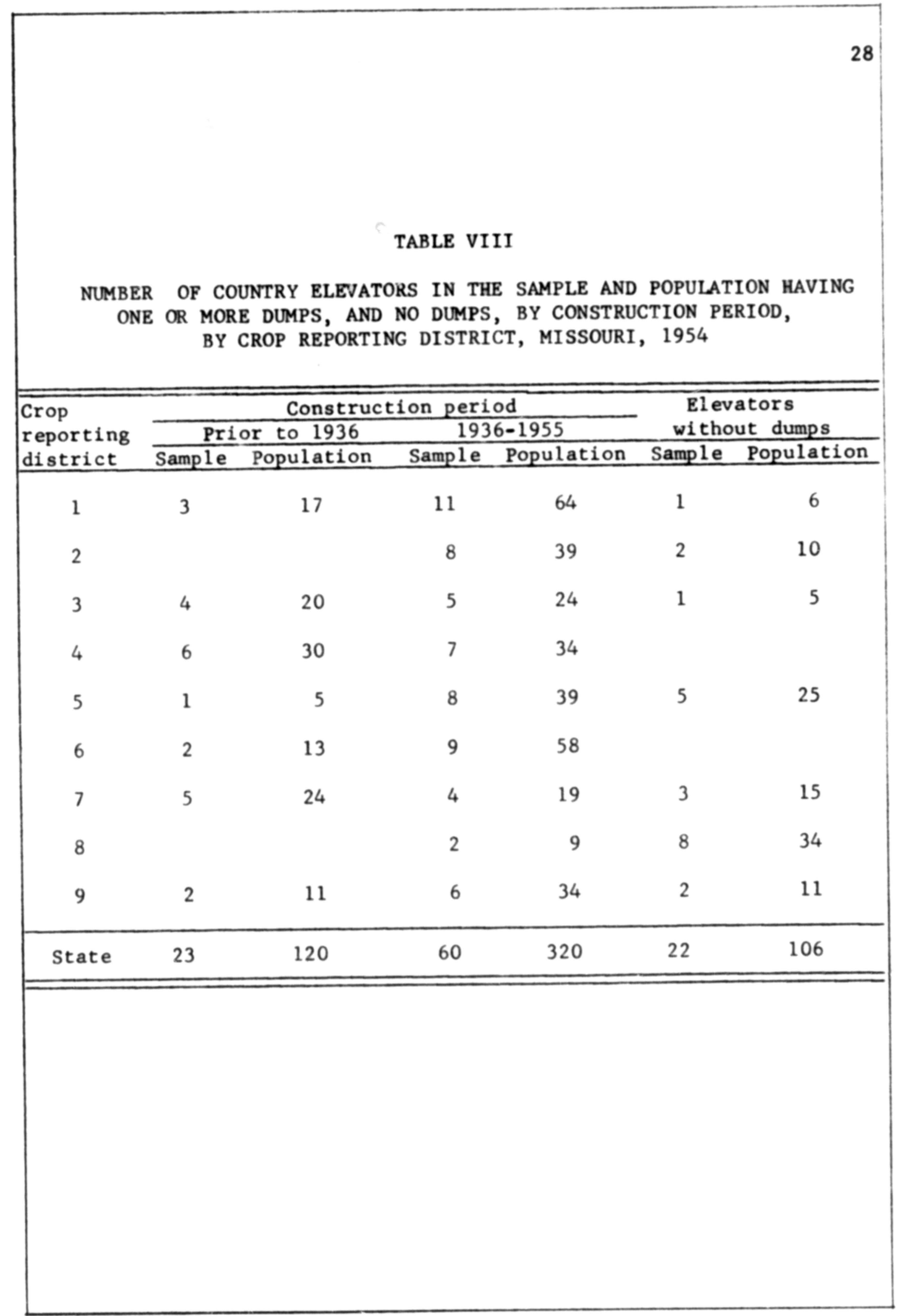


steel or wood. The legs may be either permanent or moveable. The rated capacity of 273 elevator legs in the population was less than 1,000 bushels of grain per hour, 157 had a rated capacity of 1,001-2,000 bushels, and 54 legs had a rated capacity above 2,001 bushels per hour. Only 62 country elevators in the state did not have leg equipment in 1954 (Table IX).

\section{Storage Capacity}

In 1954 the estimated total capacity for country elevators was $16,641,000$ bushels. Of this total capacity, some must be reserved for working space, leaving something less than that amount available for storage. Working space is that space needed by the operators to perform turning and biending of bulk grain and to carry on their various merchandising functions. The working space thus set aside by the elevator operators in 1954 was 5,089,000 bushels. This left 11,552,000 bushels of available storage space for the actual storage of grain received from the farmers and the grain handlers.

The mean total capacity of the 546 elevators in Missouri in 1954 was 30,478 bushels per elevator. The mean working space per elevator was 9,321 bushels, which left a mean available storage space of 21,157 bushels for the storage of grain. 
TABLE IX

NUMBER OF COUNTRY ELEVATORS IN THE SAMPLE AND POPULATION BY RATED

LEG CAPACITY AND NO LEGS, BY CROP REPORTING DISTRICT,

MISSOURI, 1954

\begin{tabular}{|c|c|c|c|c|c|c|c|c|}
\hline \multirow{3}{*}{$\begin{array}{l}\text { Crop } \\
\text { reporting } \\
\text { district }\end{array}$} & \multicolumn{6}{|c|}{ Rated leg capacity in bushels per hour } & \multirow{2}{*}{\multicolumn{2}{|c|}{$\begin{array}{c}\text { Number of el evators } \\
\text { without legs }\end{array}$}} \\
\hline & 1,000 & or less & 1,00 & $-2,000$ & 2,0 & 1 or more & & \\
\hline & Sample & Population & Sample & Population & Sample & Population & Sample & Population \\
\hline 1 & 6 & 35 & 6 & 35 & 2 & 11 & 1 & 6 \\
\hline 2 & 3 & 15 & 1 & 4 & 3 & 15 & 3 & 15 \\
\hline 3 & 5 & 24 & 3 & 15 & 2 & 10 & & \\
\hline 4 & 7 & 34 & 5 & 25 & 1 & 5 & & \\
\hline 5 & 7 & 35 & 3 & 15 & & & 4 & 19 \\
\hline 6 & 7 & 45 & 2 & 13 & 2 & 13 & & \\
\hline 7 & 7 & 34 & 4 & 19 & & & 1 & 5 \\
\hline 8 & 4 & 17 & 2 & 9 & & & 4 & 17 \\
\hline 9 & 6 & 34 & 4 & 22 & & & & \\
\hline State & 52 & 273 & 30 & 157 & 10 & 54 & 13 & 62 \\
\hline
\end{tabular}


The mean total capacity per elevator by crop reporting district in the state ranged from a low of 5,209 bushels in Crop Reporting District 8 to a high of 56,393 bushels in Crop Reporting District 9. The working space per country elevator in 1954 varied from 2,512 bushels in Crop Reporting District 8 to a high of 20,500 bushels in Crop Reporting District 9. The available storage space per elevator ranged from a high of 48,408 bushels in Crop Reporting District 3 to a low of 2,698 bushels in Crop Reporting District 8 (Table X). Crop Reporting District 8 has the lowest total capacity, working space, and available storage space per country elevator in the state. The low productivity of the soil and rough topography are some reasons for the low storage capacity of the country elevators in that Crop Reporting District. 


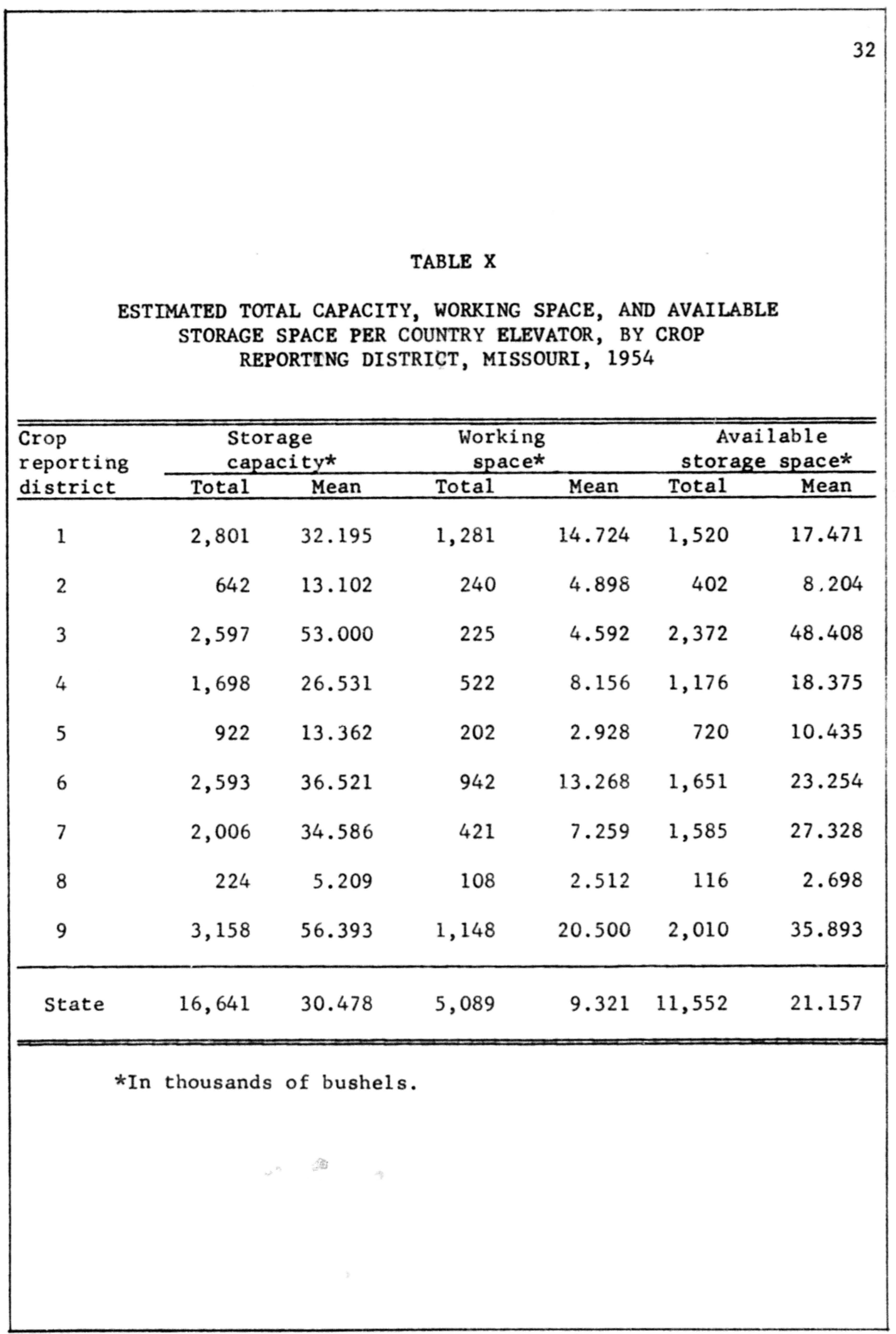




\section{CHAPTER III}

\section{SOURCE OF RECEIPTS OF COUNTRY ELEVATORS}

The demand for country elevators to operate at top storage capacity and at top receiving and shipping capacity is greatest in those marketing areas where the largest amount of grain is harvested. The use of the combine and truck has concentrated the grain deliveries into a few hours of the day and shortened the harvesting period to as much as three weeks. This requires better equipped elevators, and demands top performance of the storage facilities at their peak capacities for just a small portion of the year.

\section{RECEIPTS FROM FARMERS}

The 105 country elevators in the sample reported a total of $14,201,346$ bushels of corn, wheat, oats, barley, grain sorghum, and soybeans received direct from the farmers in 1954. This would indicate that the 546 country elevators in Missouri received 73,847,000 bushels of those grains from farmers. The total production of those six grains in Missouri that year was $204,754,000$ bushels. 1 From these data it can be estimated that the country

$1_{\text {These }}$ six grains constituted 99.5 per cent of total grain produced in Missouri in 1954. 
elevators received about 36 per cent of those grains produced in Missouri.

In analyzing the requirements for the receiving facilities of country elevators one needs to consider the type of grain received, amount of grain produced, geographic location, and the type of farming enterprises predominating in the area.

The portion of production received by country elevators will vary by type of grain. Large portions of the production of wheat and soybeans move into the commercial channels as compared to a smaller portion of the feed grains. For example, the receipt of soybeans by country elevators was 78.83 per cent of the total production of soybeans in Missouri. The percentage for wheat was 65.69 per cent. However, only 27.86 per cent of the corn, 8.47 per cent of the oats, 12.99 per cent of the barley, and 50.19 per cent of the grain sorghum was received direct from the farmers (Table XI). These percentages for the feed grains are smaller than for soybeans and wheat because more of the feed grains are fed on farms where grown or moved directly from producers to livestock feeders by truck, thus by-passing the country elevator.

The portion of production received directly from farmers by country elevators varied tremendousidy by 


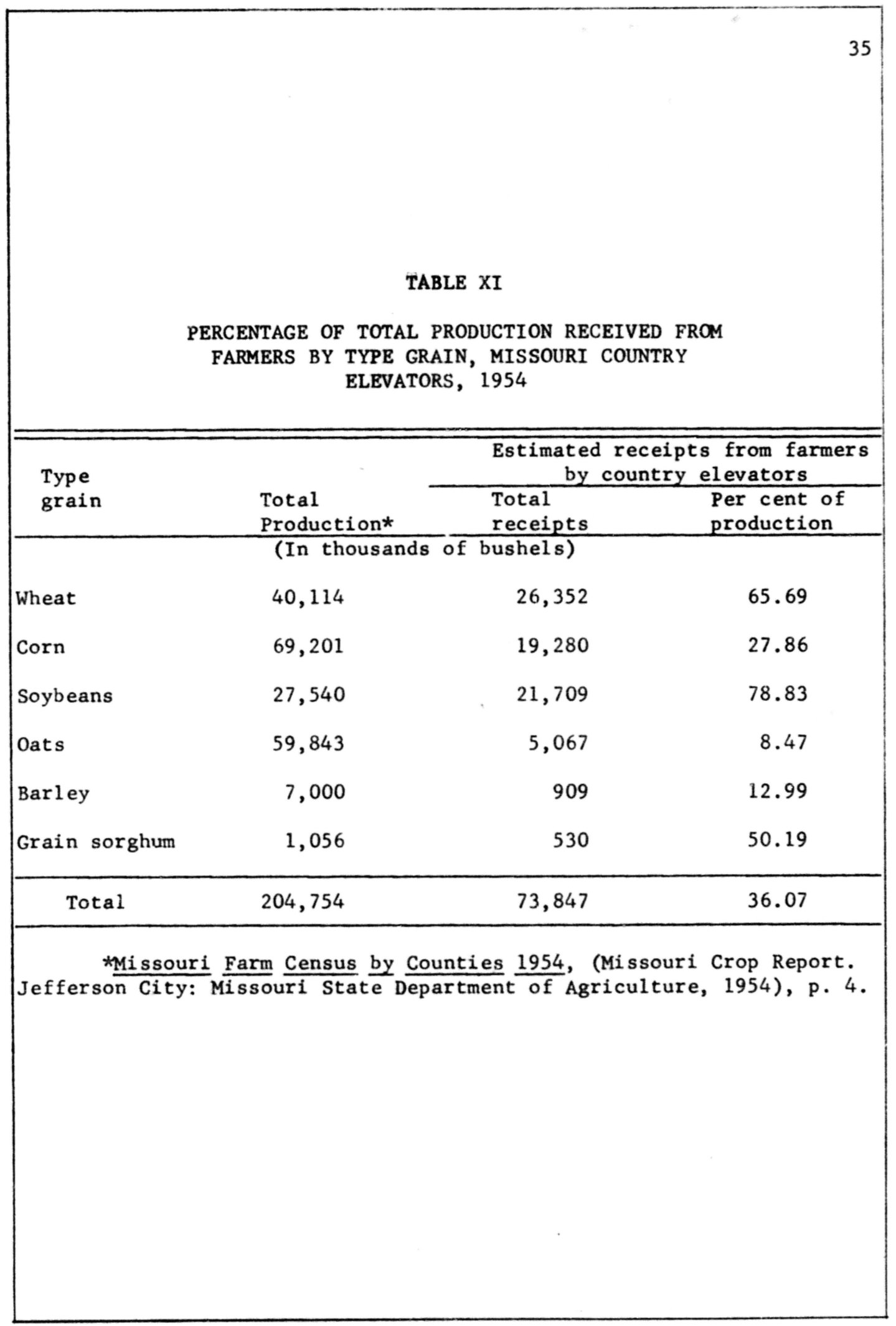


geographic location. For instance, corn receipts varied from 2,832,000 bushels, which was 71 per cent of production, in the Eastern part of Missouri $\left(\mathrm{CRD}^{2}\right.$ 6) to 424,000 bushels, which was 6 per cent of production, in the Central part (CRD 5). Even though the two areas lie next to each other, the grain producers in CRD 6 sold considerably more of their corn to the country elevators than farmers in CRD 5. The country elevators located in CRD 4 (West) received $1,756,000$ bushels of oats, which was 17 per cent of production, direct from farmers as compared to 86,000 bushels, which was 3 per cent of production, in CRD 8 (South Central Missouri). The variation in the receipts of barley was 41,000 bushels, or 44 per cent of production, in the Northwest (CRD 1) to 30,000 bushels, which was 2 per cent of production, in the Central part (CRD 5). The country elevators received 47,000 bushels of grain sorghum, which was 82 per cent of production, in Northwest Missouri (CRD 1) to 19,000 bushels, which amounted to 22 per cent of production, in Southwest (CRD 7). From the data presented, it was observed that the country elevators located in the Central part of Missouri (CRD 5) received the least portion of the total production of corn and barley direct from the farmers in their

${ }^{2}$ CRD, Crop Reporting District. 
district (Table XII).

The portion of these grains will vary from year to year depending upon the volume of production. The data collected pertained to 1954 which was the year of lowest production for corn in Missouri since 1936 and the year of highest production of oats on record.

\section{RECEIPTS FROM FARMERS RELATIVE TO RECE IVING FACILITIES}

The receiving capacities of Missouri country elevators were estimated at 4,950,000 bushels per 10-hour work day. According to the data collected, the country elevators received $73,847,000$ bushels of corn, wheat, oats, barley, grain sorghum, and soybeans direct from the farmers in 1954. This indicates that country elevators would have been able to receive all of the grain in about fifteen 10-hour work days for the State of Missouri. For example, in CRD 4 (West) the country elevators had the highest receiving capacity in the state, which was 753,000 bushels per 10-hour work day. Assuming the country elevators can receive grain at this rate it would have taken them only thirteen days to receive all of the grain from farmers in that particular district. The lowest receiving capacity by crop reporting district was 120,000 bushels for country elevators in CRD 8 (South Central). 
TABLE XII

TOTAL PRODUCTION AND ESTIMATED RECEIPTS RECEIVED DIRECT FROM FARMERS AT COUNTRY ELEVATORS, BY TYPE GRAIN, BY CROP REPORTING DISTRICT, MISSOURI, 1954

\begin{tabular}{|c|c|c|c|c|c|c|}
\hline \multirow[t]{3}{*}{$\begin{array}{l}\text { Crop } \\
\text { reporting } \\
\text { district } \\
\end{array}$} & $\begin{array}{l}\text { Total } \\
\text { production* }\end{array}$ & $\begin{array}{l}\text { Receipts } \\
\text { from } \\
\text { farmers }\end{array}$ & $\begin{array}{l}\text { Total } \\
\text { production* }\end{array}$ & $\begin{array}{l}\text { Receipts } \\
\text { from } \\
\text { farmers }\end{array}$ & $\begin{array}{l}\text { Total } \\
\text { production* }\end{array}$ & $\begin{array}{l}\text { Receipts } \\
\text { from } \\
\text { farmers }\end{array}$ \\
\hline & & & (In thous & of bushe & & \\
\hline & \multicolumn{2}{|c|}{ Wheat } & \multicolumn{2}{|c|}{ Soybeans } & \multicolumn{2}{|c|}{ Corn } \\
\hline 1 & 5,144 & 4,159 & 2,436 & 2,406 & 23,125 & 6,820 \\
\hline 2 & 3,776 & 1,686 & 5,520 & 4,960 & 11,039 & 1,396 \\
\hline 3 & 4,434 & 2,994 & 7,258 & 7,061 & 9,365 & 1,372 \\
\hline 4 & 5,905 & 4,492 & 1,220 & 1,176 & 4,705 & 1,998 \\
\hline 5 & 6,498 & 1,691 & 870 & 764 & 7,004 & 424 \\
\hline 6 & 4,900 & 4,134 & 684 & 632 & 3,959 & 2,832 \\
\hline 7 & 5,019 & 4,765 & 333 & 306 & 635 & 271 \\
\hline 8 & 1,322 & 499 & 109 & 39 & 1,660 & 275 \\
\hline 9 & 3,116 & 1,932 & 9,110 & 4,365 & 7,709 & 3,892 \\
\hline State & 40,114 & 26,352 & 27,540 & 21,709 & 69,201 & 19,280 \\
\hline
\end{tabular}

*Missouri Farm Census by Counties 1954, (Missouri Crop Report. Jefferson City: Missouri State Department of Agricul ture, 1954), pp. 10-16. 


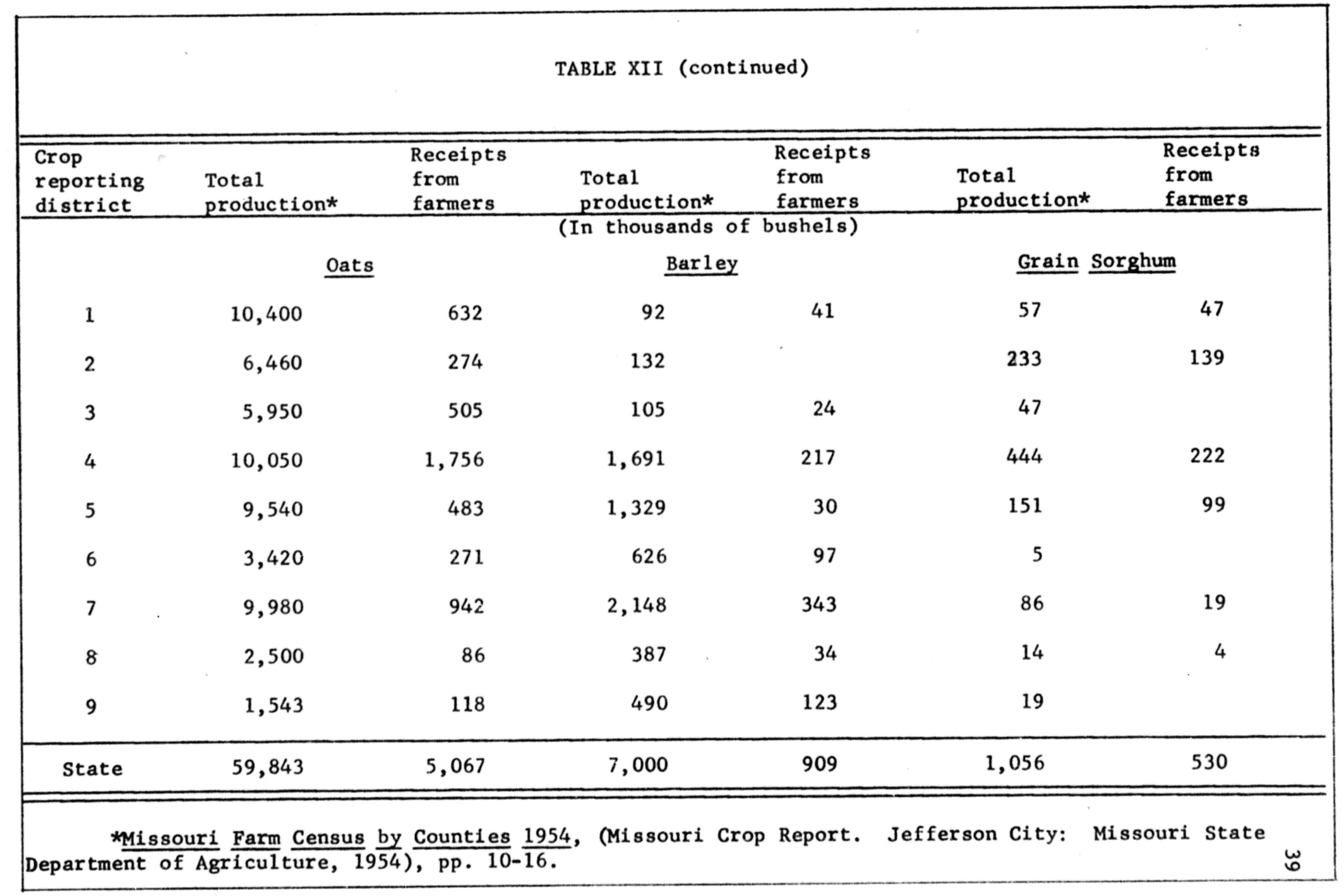


It would have taken those elevators approximately eight 10-hour work days to receive the grain from the farmers in that district (Table XIII). These data reflect that the geographic location, receipts, and total production are important in planning and carrying on an efficient elevator operation.

\section{VOLUME OF RECEIPTS FROM FARMERS RELATIVE TO STORAGE CAPACITIES}

To perform the function of assembling grain from the many producers and to move it to the terminals and processors, country elevators need adequate storage space to receive, blend, clean, and scalp grain.

The competition for available storage space between the different types of grain will vary during the year. Wheat, oats, and barley compete in the use of available storage space during June and July while corn, soybeans, and grain sorghum compete during September, October, and November. The peak marketing periods of the different types of grain will vary within the months and from year to year. The peak receiving period for a grain at country elevators will be ten days to three weeks earlier in Southern Missouri than in the Northern part of the state. The total storage capacity of the 546 country elevators in the state in 1954 was estimated at 16,641,000 
TABLE XIII

ESTIMATED TOTAL RECEIPTS FROM FARMERS AND RECEIVING CAPACITY OF MISSOURI COUNTRY ELEVATORS BY CROP REPORTING DISTRICT, 1954

\begin{tabular}{ccc}
\hline $\begin{array}{c}\text { Crop reporting } \\
\text { district }\end{array}$ & $\begin{array}{l}\text { Receiving } \\
\text { capacity* }\end{array}$ & $\begin{array}{c}\text { Total } \\
\text { receipts }\end{array}$ \\
\hline 1 & 742 & (In thousands of bushels) \\
2 & 245 & 14,105 \\
3 & 671 & 8,455 \\
4 & 753 & 11,956 \\
5 & 601 & 9,861 \\
6 & 722 & 3,491 \\
7 & 570 & 7,966 \\
8 & 120 & 6,646 \\
9 & 526 & 937 \\
\hline State & 4,950 & 73,847 \\
\hline
\end{tabular}

* Receiving capacity refers to normal receiving capacity during a 10 hour day. 
bushels, with an estimated available storage space of $11,552,000$ bushels. The total receipts of grain direct from the producers was 4.4 times larger than the total storage capacity and 6.4 times larger than the actual available storage space for grain. Since all of the different types of grain are not harvested at the same time, they compete for storage during different months of the year. For instance, wheat was received in the largest volume. The country elevators received $26,352,000$ bushels direct from farmers, and this is 2.3 times greater than the available storage space in the state. Consequently, much of the wheat passed through the receiving facilities and was stored in bins only until a truck or rail carload accumulated. The country elevator shipped the load of wheat by rail or truck to terminal or other elevators for storage. The smallest amount of grain received directly from farmers by country elevators was grain sorghum. The 530,000 bushels of grain sorghum received occupied only .05 of the total available storage space (Table XIV).

These data emphasize the role of assembly and merchandising performed by country elevators in Missouri as compared to the role of storage.

\section{RECEIPTS FROM GRAIN HANDLERS}

Many of Missouri's crop reporting districts do not 
TABLE XIV

ESTTMATED USE OF AVAILABLE STORAGE SPACE OF COUNTRY ELEVATORS BY GRAIN, BY CROP REPORTING DISTRICT, MISSOURI, 1954

\begin{tabular}{|c|c|c|c|c|c|c|c|}
\hline \multirow{2}{*}{$\begin{array}{l}\text { Crop } \\
\text { reporting } \\
\text { district }\end{array}$} & \multirow{2}{*}{$\begin{array}{l}\text { Available } \\
\text { storage } \\
\text { space* }\end{array}$} & \multicolumn{6}{|c|}{$\begin{array}{l}\text { Turnover of available storage space for grains } \\
\text { received direct from farmers }\end{array}$} \\
\hline & & Wheat & Corn & Oats & Barley & Soybeans & Grain sorghum \\
\hline 1 & 1,520 & 2.7 & 4.5 & .4 & .03 & 1.6 & .03 \\
\hline 2 & 402 & 4.2 & 3.5 & .7 & & 12.3 & .35 \\
\hline 3 & 2,372 & 1.3 & .6 & .2 & .01 & 2.98 & \\
\hline 4 & 1,176 & 3.8 & 1.7 & 1.5 & .18 & 1.0 & .19 \\
\hline 5 & 720 & 2.3 & .6 & .7 & .04 & 1.06 & .14 \\
\hline 6 & 1,651 & 2.5 & 1.7 & .2 & .06 & .4 & \\
\hline 7 & 1,585 & 3.0 & .2 & .6 & .22 & .2 & .01 \\
\hline 8 & 116 & 4.3 & 2.4 & .7 & .29 & .3 & .03 \\
\hline 9 & 2,010 & .96 & 1.9 & .06 & .06 & 2.2 & \\
\hline State & 11,552 & 2.3 & 1.7 & .4 & .08 & 1.9 & .05 \\
\hline
\end{tabular}

*In thousands of bushels. 
produce enough feed grains to fulfill their own needs. In order for the country elevators to supply the grain demanded they must receive corn, oats, barley, and grain sorghum from grain handlers or other elevators outside their immediate trade territory.

In 1954 the 105 country elevators in the sample reported a total of 4,529,808 bushels of corn, oats, barley, and grain sorghum received from grain handlers. This would indicate that approximately 23,555,000 bushels of those four grains were received from other grain handlers by the 546 country elevators in Missouri. This suggests that 47.74 per cent of the total receipts of feed grain at country elevators came from grain handlers, leaving the other 52.26 per cent coming direct from farmers. The business of supplying feed grain to farmers is about as important to country elevators in Missouri as is the business of marketing feed grain for farmers. None of the so-called cash crops, wheat and soybeans, were received from grain handlers.

The portion of the total receipts received from grain handlers varies by the type of grain. In 1954 the grain handlers supplied Missouri country grain elevators with 49.29 per cent of the corn, 42.83 per cent of the oats, 44.57 per cent of the barley, and 35.13 per cent of the grain sorghum (Table XV). 


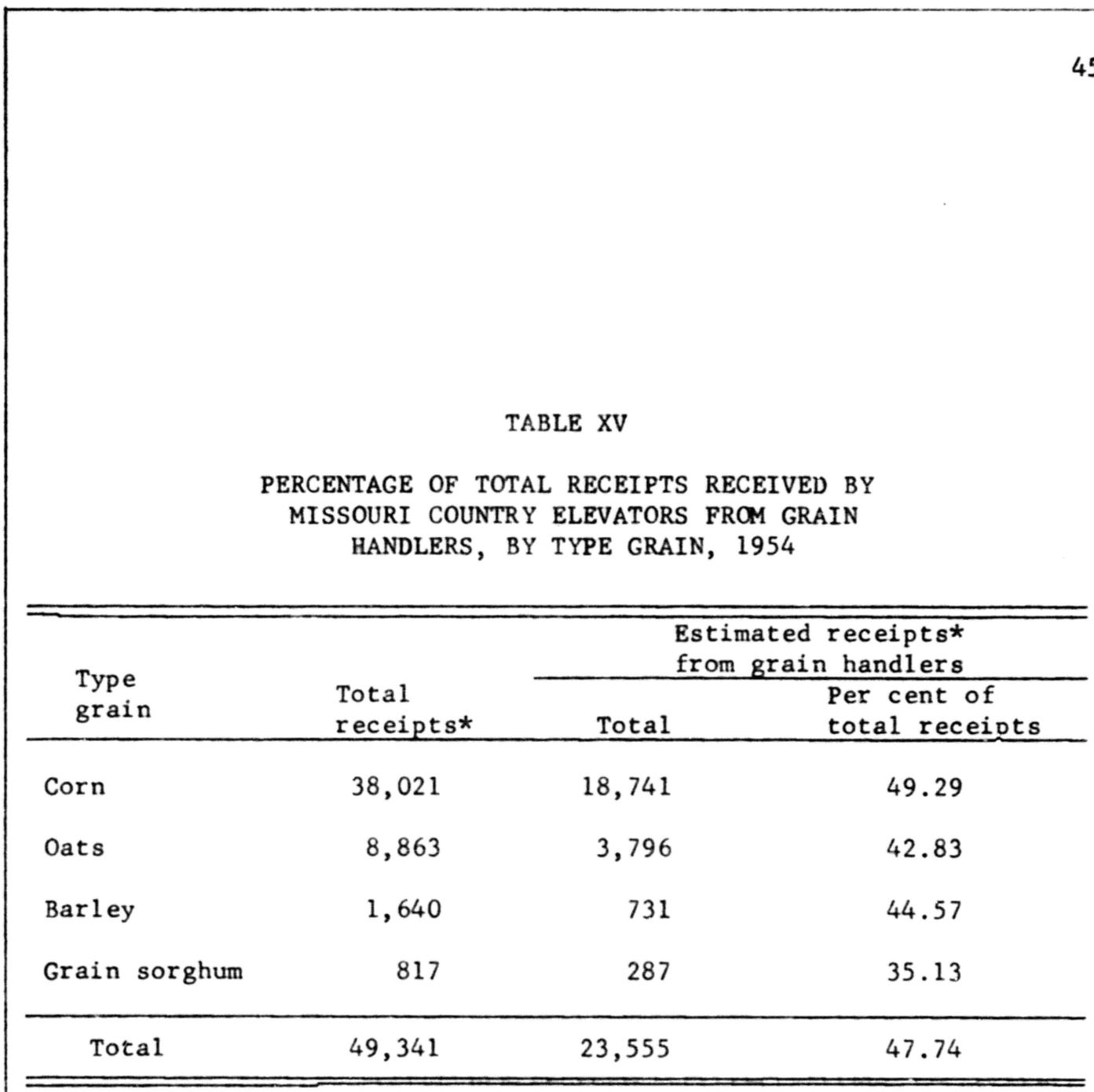

*In thousands of bushels. 
The method of transportation utilized by grain handlers for the shipment of those grains to country elevators varies by the type of grain. Approximately 80 per cent of the feed grains in the state was shipped by truck and 20 per cent by rail to the country elevators. However, truck shipments accounted for approximately 87 per cent, or 16,219,000 bushels, of corn and 69 per cent, or $2,604,000$ bushels, of oats received by country elevators, while rail facilities were utilized in supplying 85 per cent, or 619,000 bushels, of barley and 68 per cent, or 195,000 bushels, of grain sorghum (Table XVI) .

The volume of feed grain moving through country elevators from other grain handlers depends primarily upon the extent to which the area surrounding the country elevator is a feed deficit area. This varies significantly between different areas of the state.

The receipts of corn from grain handlers varied from $6,906,000$ bushels or 96 per cent of total receipts in Southwest Missouri (CRD 7) to 56,000 bushels or 1 per cent of total receipts in Southeast Missouri (CRD 9). The country elevators located in Central (CRD 5), Southwest (CRD 7), and South Central (CRD 8) Missouri received more of their corn from grain handlers than they did from the local farmers. Those areas are not well adapted to the 


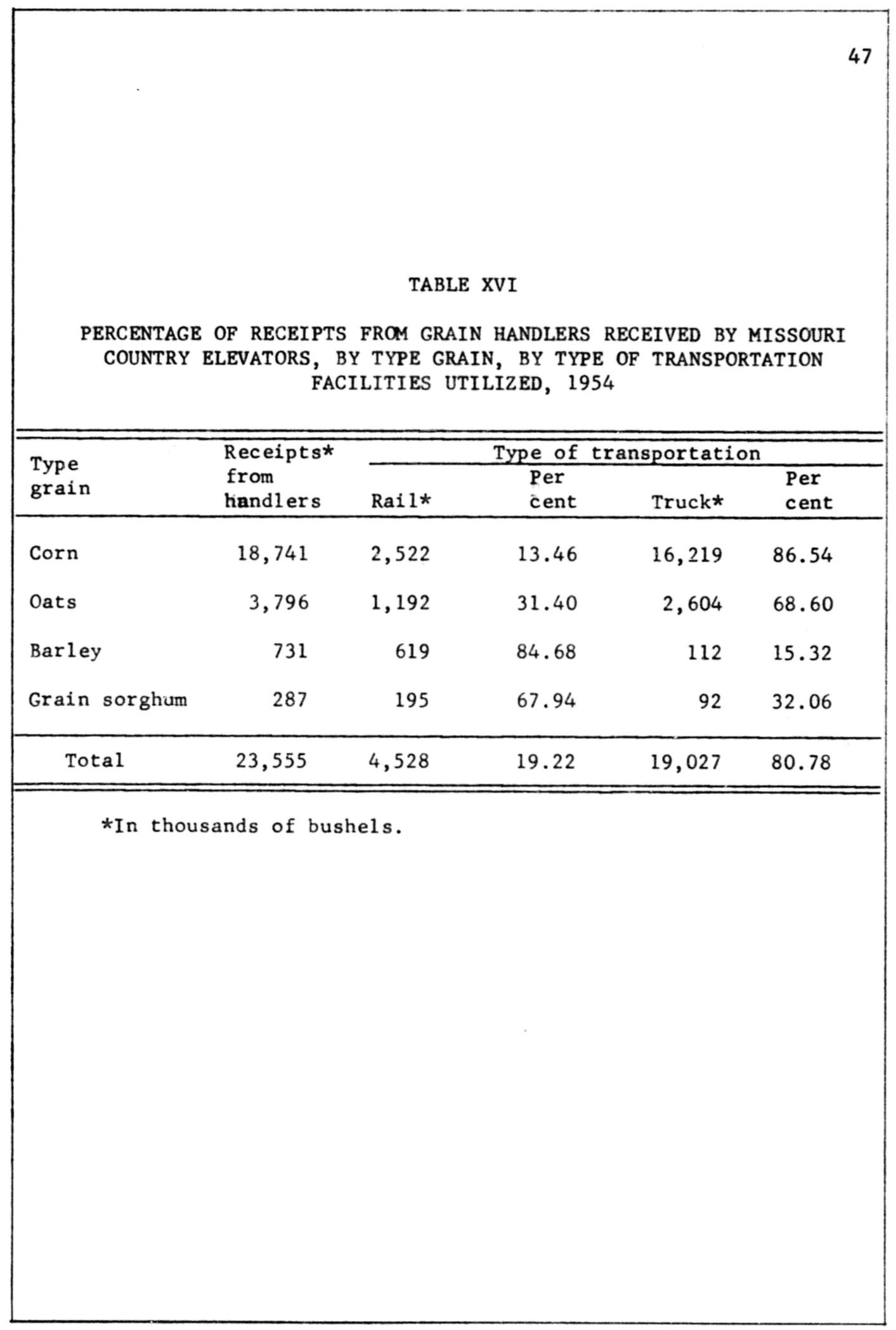


production of corn, yet considerable corn is used there in poultry, dairy, and other livestock rations. The country elevators located in the West side (CRD 4) and East side (CRD 6) of the state received a little more than 50 per cent of the corn handled from other grain handlers. Those two areas are corn-producing areas but because of the drought condition over the entire state in 1954, many elevators bought more corn from outside sources to fulfill the demand in the immediate trade area.

In the case of oats, the country elevators in the bootheel area of Missouri (CRD 9) received none from grain handlers in 1954. Receipts of oats in the remaining eight Crop Reporting Districts varied from 525,000 bushels, which was 86 per cent of total receipts, in South Central Missouri (CRD 8), to 54,000 bushels or 16 per cent of total receipts in North Central Missouri (CRD 2).

The receipts of barley from other handlers were greatest in the Northwest (CRD 1) and Northeast (CRD 3) parts of Missouri. The elevators within both districts received 86 per cent of the total receipts of their respective crop reporting district direct from grain handlers, as compared to only 12 per cent of total receipts in Southwest (CRD 7) Missouri. The country elevators located in South Central (CRD 8), Southeast (CRD 9), and North Central (CRD 2) Missouri did not receive appreciable 
amounts of barley from grain handlers at the time this study was conducted.

The variation in grain sorghum receipts ranged from a high of 208,000 bushels, which was 92 per cent of total receipts, in Southwest (CRD 7) Missouri to 10,000 bushels or 9 per cent of total receipts in Central (CRD 5) Missouri. The country elevators located within the Northwest (CRD 1), North Central (CRD 2), Northeast (CRD 3), East (CRD 6), and Southeast (CRD 9) areas of Missouri reported that they did not receive grain sorghum from grain handlers in 1954 (Table XVII).

As has been previously pointed out the receipts of the various feed grains will vary from year to year depending upon the prevailing weather conditions throughout the crop year and number of livestock fed on the farm.

\section{RELATIONSHIP OF GRAIN SUPPLIED BY FARMERS} AND GRAIN HANDLERS

The farmers supplied the local country elevators with $73,847,000$ bushels of grain (75.82 per cent of the total receipts), and grain handlers supplied 23,555,000 bushels (24.18 per cent) in 1954. The portion of receipts direct from farmers and grain handlers will vary each year depending upon weather conditions, type of grain, number of livestock fed on farms, and geographic location. 


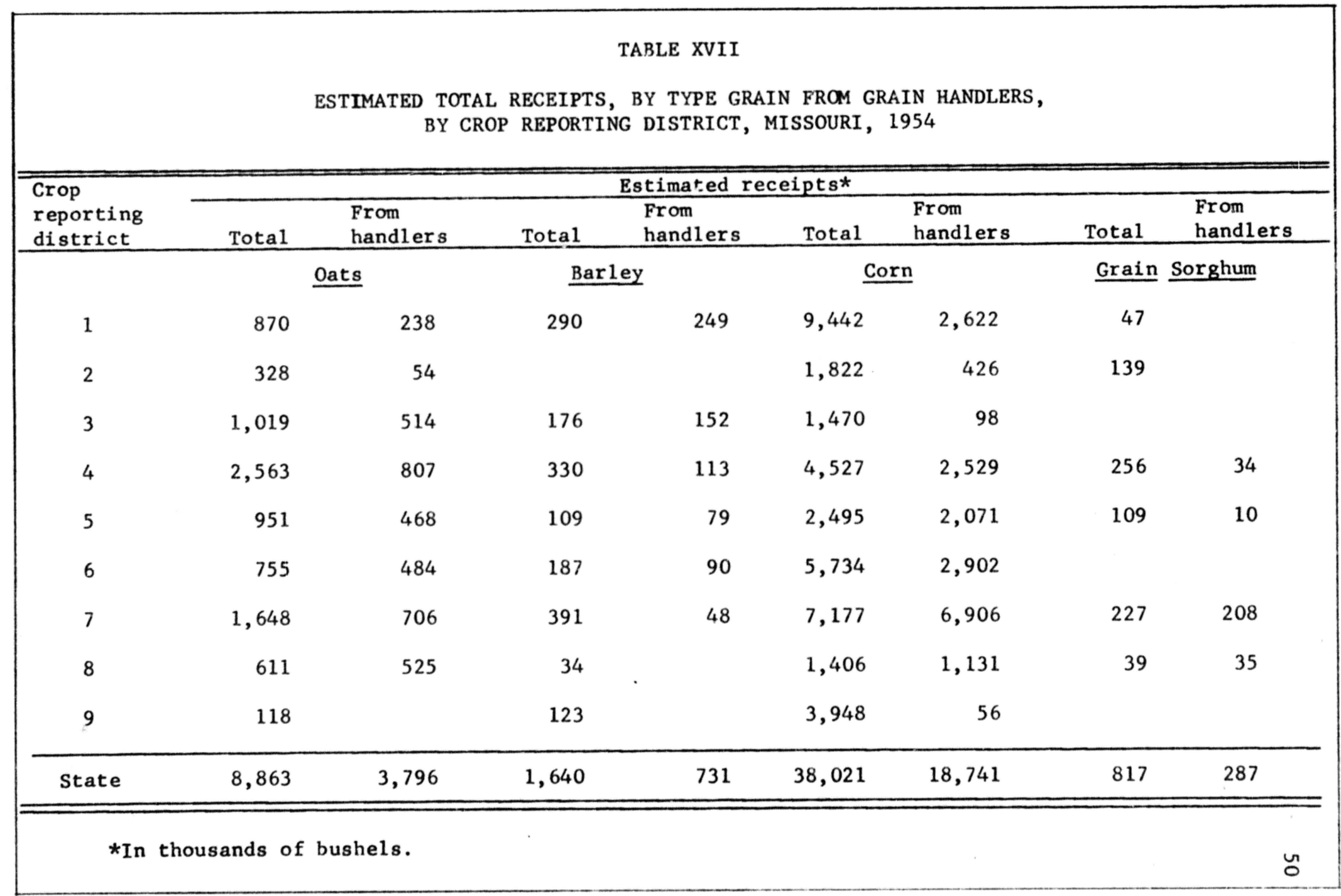




\section{CHAPTER IV}

TOTAL HANDLING VOLUME OF COUNTRY ELEVATORS

The total handling volume of country elevators includes grain sold locally and to outside sources, the grain shipped to terminal or other elevators for storage, and the grain shipped for Commodity Credit Corporation.

\section{VOLUME OF EACH TYPE OF GRAIN THAT COMPRISES} TOTAL HANDLING VOLUME

If the sample in this study is representative, then the total handling volume of Missouri's 546 country elevators in 1954 was $97,402,000$ bushels of corn, oats, wheat, barley, soybeans, and grain sorghum. The country elevators sold approximately 37.88 per cent or $36,898,000$ bushels of the grain handled to buyers within the local trade area; 59.68 per cent or $58,125,000$ bushels to outside buyers such as grain handlers, processors, and terminal markets, shipped 0.6 per cent, which was 592,000 bushels, for storage to terminal or other elevators, and handled 1.83 per cent or $1,787,000$ bushels for Commodity Credit Corporation (Figure 3).

There is a notable difference in the amount of grain handled by country elevators by type of grain. From previous studies and observations it is known that a very 


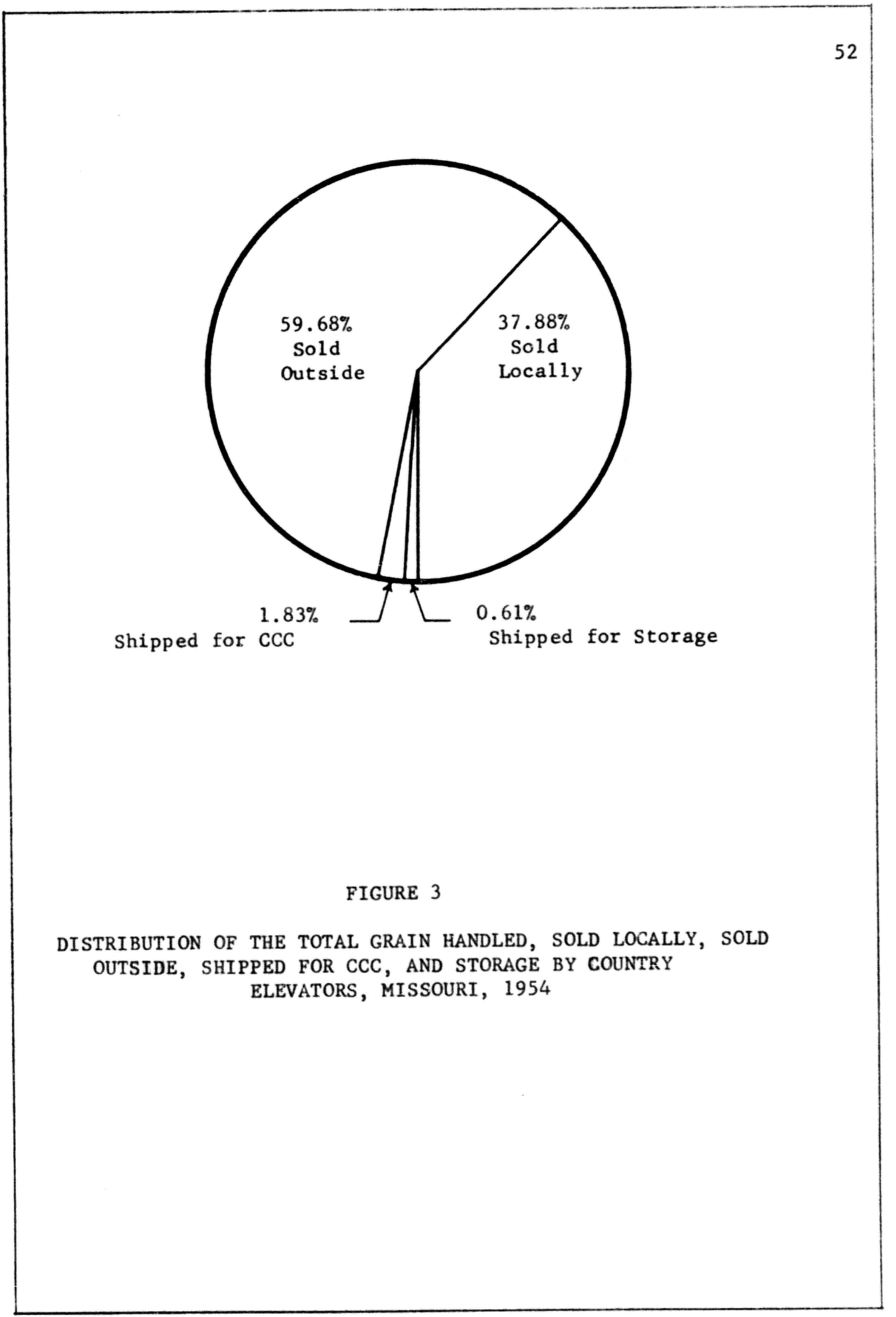


large portion of the wheat and soybeans handled in Missouri is marketed through commercial channels, while a relatively small portion of Missouri-grown oats, corn, barley, and grain sorghum finds its way into commercial channels of trade. In 1954 Missouri country elevators sold to outside sources approximately 93 per cent, which was $24,631,000$ bushels, of the wheat handled, shipped 2 per cent, or 580,000 bushels, to terminal or other elevators for storage, shipped 4 per cent $(1,115,000$ bushels) for Commodity Credit Corporation, and returned less than 0.1 per cent to the local farmers. Missouri country elevators sold approximately 99 per cent $(21,487,000$ bushels) of the soybeans to outside sources, 0.5 per cent (112,000 bushels) was shipped for Commodity Credit Corporation, 0.4 per cent $(98,000$ bushels) was sold locally and the remainder shipped for storage. Only the local producers supplied those two cash crops to the country elevators.

The data collected in this study indicate a large percentage of the feed grains handled by country elevators was sold in the immediate trade area. In 1954 the country elevators handled $38,021,000$ bushels of corn of which $27,798,000$ bushels (approximately 74 per cent) were sold locally, 25 per cent $(9,663,000$ bushels) was sold to outside sources, and 560,000 bushels ( 1 per cent) were 


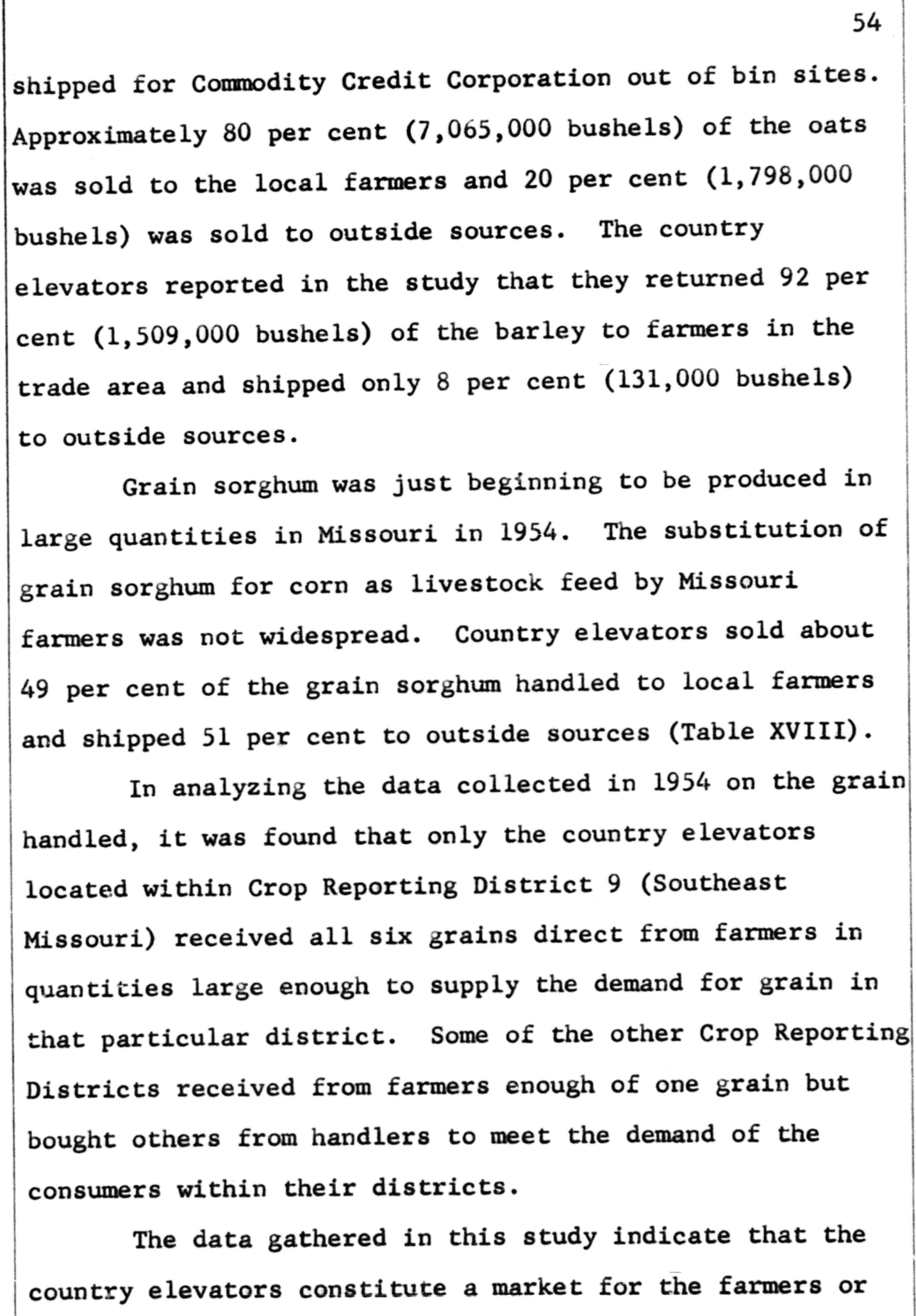


TABLE XVIII

ESTIMATED TOTAL BUSHELS* OF GRAIN HANDLED, MERCHANDISED, SHIPPED

FOR STORAGE, AND COMMODITY CREDIT CORPORATION, BY TYPE

GRAIN, MISSOURI COUNTRY ELEVATORS, 1954

\begin{tabular}{|c|c|c|c|c|c|c|}
\hline \multirow{2}{*}{ Type grain } & \multirow[b]{2}{*}{$\begin{array}{l}\text { Total } \\
\text { handled }\end{array}$} & \multicolumn{3}{|c|}{ Merchandised } & \multirow[b]{2}{*}{$\begin{array}{l}\text { Shipped } \\
\text { for storage }\end{array}$} & \multirow[b]{2}{*}{$\begin{array}{l}\text { Shipped } \\
\text { for CCC }\end{array}$} \\
\hline & & Total & $\begin{array}{l}\text { Sold } \\
\text { loca11y }\end{array}$ & $\begin{array}{l}\text { Sold } \\
\text { outside }\end{array}$ & & \\
\hline Corn & 38,021 & 37,461 & 27,798 & 9,663 & & 560 \\
\hline Wheat & 26,352 & 24,657 & 26 & 24,631 & 580 & 1,115 \\
\hline Oats & 8,863 & 8,863 & 7,065 & 1,798 & & \\
\hline Barley & 1,640 & 1,640 & 1,509 & 131 & & \\
\hline Soybeans & 21,709 & 21,585 & 98 & 21,487 & 12 & 112 \\
\hline Grain sorghum & 817 & 817 & 402 & 415 & & \\
\hline Total & 97,402 & 95,023 & 36,898 & 58,125 & 592 & 1,787 \\
\hline
\end{tabular}

*In thousands of bushels. 
feeders who must buy grain to carry on his feeding enterprise, as well as a cash market for the farmers who produce surplus grain. 


\section{CHAPTER V}

\section{STORAGE}

The total storage capacity of a country elevator includes the available storage space plus the required working space needed to condition and hold grain until a sufficient amount for shipment can be assembled. The available storage space is used to store grain for the country elevator, farmers, processors, and Commodity Credit Corporation.

\section{TURNOVER IN AVAILABLE STORAGE SPACE BY TYPE GRAIN FOR THE STATE}

The 546 country elevators in the state provided $11,552,000$ bushels of available storage space in 1954. The available storage space represented approximately 12 per cent of the total amount of grain handled by the country elevators. This space would store about one sixth of the corn produced, which is the largest grain crop in Missouri, and ten times the grain sorghum produced. Slightly more than 5 per cent of all grain produced in Missouri could have been stored in country elevators (Table XIX). As has been pointed out, not all of the grain produced in Missouri goes through country elevators, and a small part of that merchandised through the country elevator is stored for 


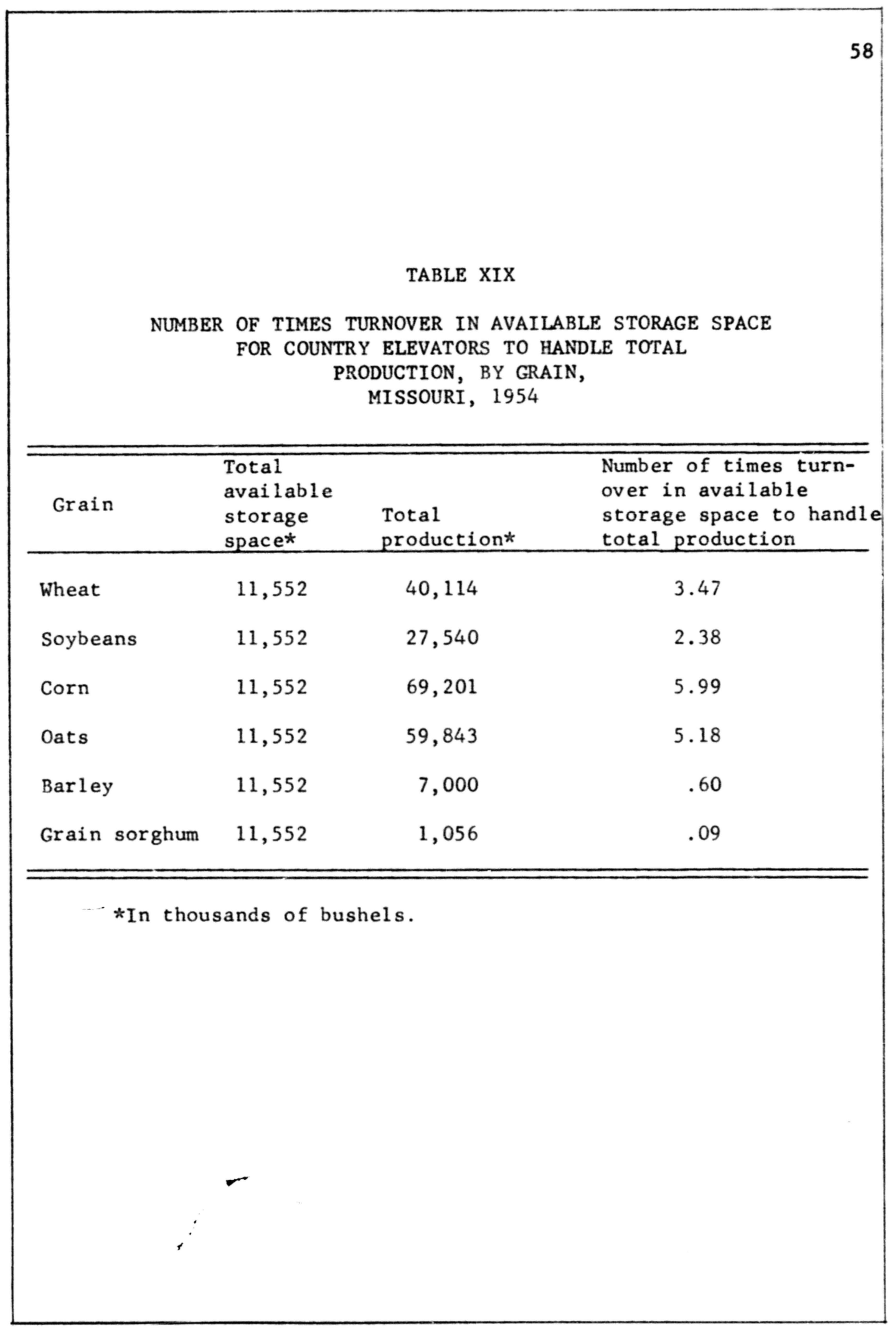


long periods of time.

\section{UTILIZATION OF AVAILABLE STORAGE SPACE BY TYPE GRAIN FOR THE STATE}

Each type of grain produced in an area has its own peak seasonal movement through the country elevator. The peak inventory of grains refers to the largest number of bushels of each type of grain that the country elevators had on hand at any one time during the year 1954. The peak inventory for wheat was $8,071,000$ bushels (70 per cent), which was the largest percentage of available storage space utilized by any one grain in the state. The lowest per cent of available storage space utilized by a grain was 2.69 per cent (Table $\mathrm{XX}$ ). This was for grain sorghum which was a relatively new crop for the State of Missouri in 1954. The marketing season for each type of grain may cover a period of less than a month, with peak marketing and peak inventory for that particular type grain coming within a two-week period.

III. TURNOVER IN AVAILABLE STORAGE SPACE COMPARED WITH PEAK INVENTORY BY TYPE GRAIN, BY CROP REPORTING DISTRICTS

The number of times turnover and the percentage of available storage space utilized during peak inventory may 
TABLE XX

PER CENT OF TOTAL AVAILABLE STORAGE SPACE UTILIZED

DURING PEAK INVENTORY BY TYPE

GRAIN, MISSOURI, 1954

\begin{tabular}{lccc}
\hline $\begin{array}{l}\text { Type } \\
\text { grain }\end{array}$ & $\begin{array}{l}\text { Total avail- } \\
\text { able storage } \\
\text { space* }\end{array}$ & $\begin{array}{l}\text { Total } \\
\text { peak } \\
\text { Inventory* }\end{array}$ & $\begin{array}{l}\text { Per cent of available } \\
\text { storage space utilized } \\
\text { during peak inventory }\end{array}$ \\
\hline Wheat & 11,552 & 8,071 & 69.87 \\
Corn & 11,552 & 5,047 & 43.69 \\
Soybeans & 11,552 & 5,598 & 48.46 \\
Barley & 11,552 & 498 & 4.31 \\
Oats & 11,552 & 2,218 & 19.20 \\
Grain sorghum & 11,552 & 311 & 2.69 \\
\hline \hline
\end{tabular}

*In thousands of bushels. 
be rather misleading in the preceding analysis, since the two are based on the consolidated Crop Reporting District figures, by type grain for the State of Missouri. A better indication as to the utilization of available storage space can be obtained by type grain by geographic location.

It was found that the country elevators of each crop reporting district in the state varied as to the number of times turnover in the available storage space for each type grain handled. Soybeans in CRD 2 (North Central Missouri) reflected a 12.3 times turnover in available storage space of country elevators, which was the greatest number of times turnover for any one type grain in the nine crop reporting districts in the state. The country elevators located within CRD 2 had 402,000 bushels of available storage space which, according to the data in the study, was next to the lowest available storage space in the state in 1954. In that particular crop reporting district the soybeans received by the country elevators came directly from the producers. This probably resulted in a long line of trucks and wagons waiting to unload their grain during the peak marketing period. The percentage of available storage space utilized during peak inventory, which was 89.30 per cent, indicates that the available storage space of the country elevators was utilized largely to receive and ship the soybeans to outside sources such 
as terminal or other elevators and processors. Corn was a close second with 12.1 times turnover in available storage space of the country elevators located within CRD 8 (South Central Missouri). However, the portion of turnover in total corn handled by country elevators was different than in the case of soybeans because almost ten times out of the 12.1 times turnover in available storage space were accounted for by the receipts of corn from grain handlers. Since the data indicate that a large part of the turnover in available storage space can be accounted for by the shipment of corn into this deficit feed area, the problem of building additional storage space becomes one of having storage space available to store grain which the country elevators buy from grain handlers, rather than one of storing the grain produced in the area. Considering the percentage of available storage space utilized during peak inventory, which was 59.48 per cent, the data indicate that a peak marketing period for corn in CRD 8 does not occur, but rather the buying of corn from grain handlers continues throughout the year depending upon the demand by the fartiers.

The lowest turnover in available storage space of the four grains analyzed was oats in CRD 9 (Southeast Missouri). The available storage space in that crop reporting district for the country elevators was 
$2,010,000$ bushels. Since only 118,000 bushels of oats were received by the country elevators, this was a turnover in available storage space of .05 times for the oat crop, which was received direct from the producers. The peak inventory for the oats handled was 34,000 bushels. This was 1.69 per cent of the total available storage space being utilized during the peak inventory for oats.

(Tables XXI and XXII)

The lowest turnover in available storage space of the six grains studied in 1954 was for barley and grain sorghum. Considering the two grains separately, they did not reflect a turnover in available storage space of at least once. Therefore, because of the low handling yolume and low peak inventory by country elevators in all drop reporting districts an analysis of available storage space, turnover of available storage space, peak ínventory, and per cent utilization of available storage space during peak inventory, by type of grain and by crop reporting districts was not made. However, tables of basic data concerning those two grains may be found in Appendix B, pages $100,101,104$.

IV. AVERAGE INVENTORY UTILIZATION OF AVAILABLE STORAGE SPACE

Average inventory refers to the average bushel 


\begin{tabular}{|c|c|c|c|c|c|c|c|c|c|}
\hline \multirow[b]{3}{*}{$\begin{array}{l}\text { Crop } \\
\text { reporting } \\
\text { district }\end{array}$} & \multirow{3}{*}{$\begin{array}{l}\text { ER OF TIMES } \\
\text { Tota1 } \\
\text { available } \\
\text { storage } \\
\text { space* }\end{array}$} & \multicolumn{8}{|c|}{$\begin{array}{l}\text { TABLE XXI } \\
\text { RAGE SPACE FOR GRAIN HANDLED BY THE COUNTRY ELEVATORS, } \\
\text { REPORTING DISTRICT, MISSOURI, } 1954\end{array}$} \\
\hline & & \multicolumn{2}{|c|}{ Soybeans } & \multicolumn{2}{|c|}{ Wheat } & \multicolumn{2}{|l|}{ Corn } & \multicolumn{2}{|c|}{ Oats } \\
\hline & & $\begin{array}{l}\text { Total } \\
\text { grain } \\
\text { handled* }\end{array}$ & $\begin{array}{l}\text { Turn- } \\
\text { over } * *\end{array}$ & $\begin{array}{l}\text { Total } \\
\text { grain } \\
\text { handled* }\end{array}$ & $\begin{array}{l}\text { Turn- } \\
\text { over** }\end{array}$ & $\begin{array}{l}\text { Total } \\
\text { grain } \\
\text { handled* }\end{array}$ & $\begin{array}{l}\text { Turn- } \\
\text { over } * * ?\end{array}$ & $\begin{array}{l}\text { Total } \\
\text { grain } \\
\text { handled* }\end{array}$ & $\begin{array}{l}\text { Turn- } \\
\text { over** }\end{array}$ \\
\hline 1 & 1,520 & 2,406 & 1.6 & 4,159 & 2.7 & 9,442 & 6.2 & 870 & .6 \\
\hline 2 & 402 & 4,960 & 12.3 & 1,686 & 4.2 & 1,822 & 4.5 & 328 & .8 \\
\hline 3 & 2,372 & 7,061 & 2.98 & 2,994 & 1.3 & 1,470 & .6 & 1,019 & .4 \\
\hline 4 & 1,176 & 1,176 & 1.0 & 4,492 & 3.8 & 4,527 & 3.8 & 2,563 & 2.2 \\
\hline 5 & 720 & 764 & 1.06 & 1,691 & 2.3 & 2,495 & 3.5 & 951 & 1.3 \\
\hline 6 & 1,651 & 632 & .4 & 4,134 & 2.5 & 5,734 & 3.5 & 755 & .5 \\
\hline 7 & 1,585 & 306 & .2 & 4,765 & 3.0 & 7,177 & 4.5 & 1,648 & 1.04 \\
\hline 8 & 116 & 39 & .3 & 499 & 4.3 & 1,406 & 12.1 & 611 & 5.3 \\
\hline 9 & 2,010 & 4,365 & 2.2 & 1,932 & .96 & 3,948 & 1.96 & 118 & .06 \\
\hline State & 11,552 & 21,709 & 1.9 & 26,352 & 2.3 & 38,021 & 3.3 & 8,863 & .8 \\
\hline * & $\begin{array}{l}\text { housands } \\
\text { nover in }\end{array}$ & $\begin{array}{l}\text { of bushels. } \\
\text { otal availab }\end{array}$ & e storage & space & ary to & re for to & ain $h$ & ndled. & $\nsubseteq$ \\
\hline
\end{tabular}


TABLE XXII

PER CENT OF TOTAL AVAILABLE STORAGE SPACE UTILIZED BY COUNTRY ELEVATORS DURING PEAK INVENTORY, BY CROP REPORTING

DISTRICT, BY TYPE GRAIN, MISSOURI, 1954

\begin{tabular}{|c|c|c|c|c|c|}
\hline \multirow[b]{2}{*}{$\begin{array}{l}\text { Crop } \\
\text { reporting } \\
\text { district }\end{array}$} & \multirow{2}{*}{$\begin{array}{l}\text { Total } \\
\text { available } \\
\text { storage } \\
\text { space* }\end{array}$} & \multicolumn{2}{|c|}{ Corn } & \multicolumn{2}{|c|}{ Wheat } \\
\hline & & $\begin{array}{l}\text { Total* } \\
\text { peak } \\
\text { inventory }\end{array}$ & $\begin{array}{l}\text { Per cent** } \\
\text { utilized } \\
\text { during peak }\end{array}$ & $\begin{array}{l}\text { Total* } \\
\text { peak } \\
\text { inventory }\end{array}$ & $\begin{array}{l}\text { Per cent** } \\
\text { utilized } \\
\text { during peak }\end{array}$ \\
\hline 1 & 1,520 & 731 & 48.09 & 1,207 & 79.41 \\
\hline 2 & 402 & 225 & 55.97 & 309 & 76.87 \\
\hline 3 & 2,372 & 294 & 12.39 & 1,000 & 42.16 \\
\hline 4 & 1.176 & 669 & 56.89 & 1,069 & 90.90 \\
\hline 5 & 720 & 212 & 29.44 & 542 & 75.28 \\
\hline 6 & 1,651 & 587 & 35.55 & 1,290 & 78.13 \\
\hline 7 & 1,585 & 1,073 & 67.70 & 1,421 & 89.65 \\
\hline 8 & 116 & 69 & 59.48 & 47 & 40.52 \\
\hline 9 & 2,010 & 1,187 & 59.05 & 986 & 49.05 \\
\hline State & 11,552 & 5,047 & 43.69 & 7,871 & 68.14 \\
\hline
\end{tabular}

*In thousands of bushels.

**Per cent of total available storage space utilized during the peak inventory. 


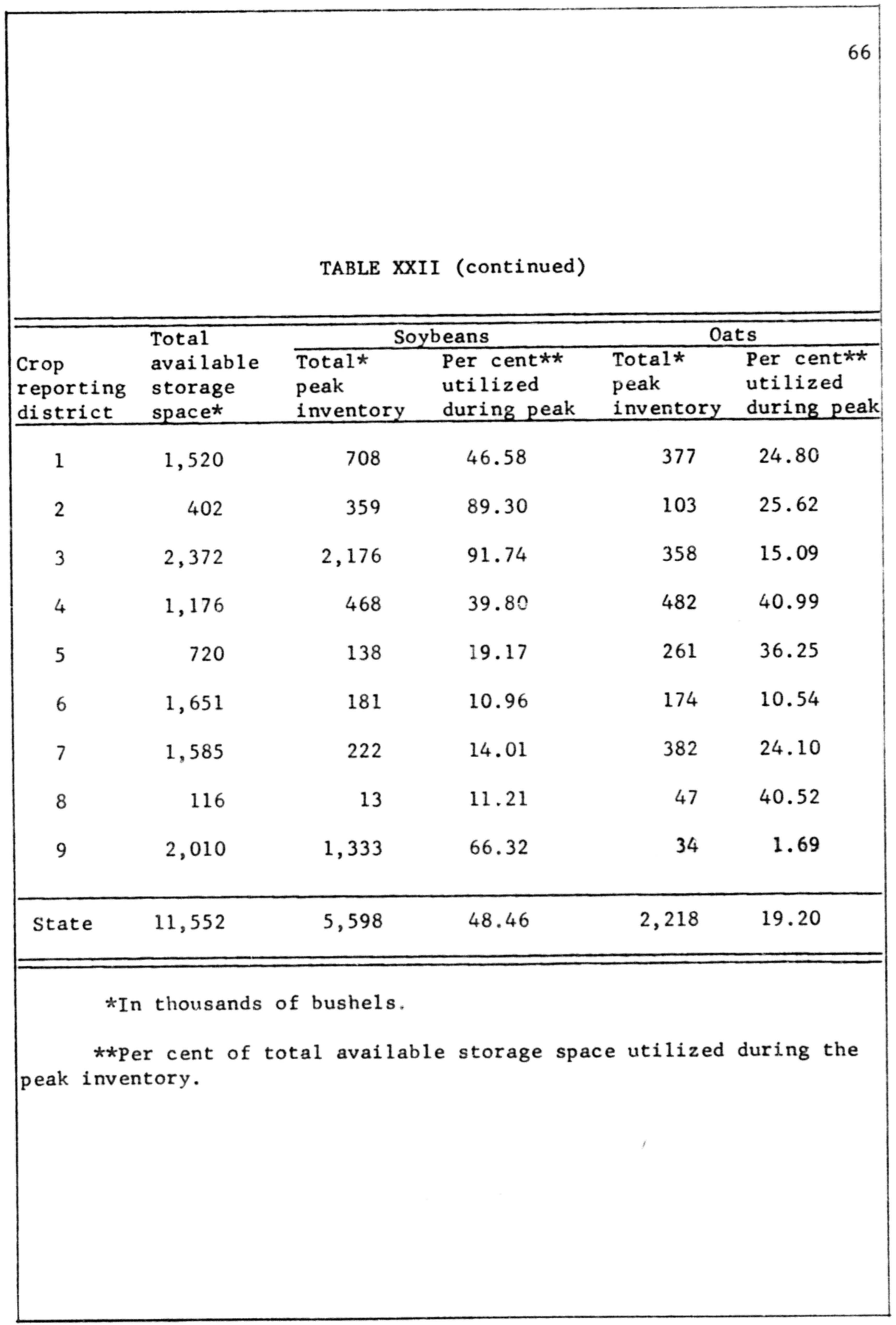


months of storage provided for a type of grain. A bushel month of storage can be defined as a bushel of grain stored for one month. The average inventories of corn, wheat, oats, barley, soybeans, and grain sorghum were combined and used to calculate the average utilization of the total available storage space by crop reporting districts for the country elevators in Missouri during 1954. From month to month, or from week to week the actual volume of grain stored may deviate considerably from the figures reported. If the data collected are representative, the 546 country elevators in the state had total available storage space of $11,552,000$ bushels. The six grains in the study occupied 6,018,000 bushels of the actual available storage space for a 12-month period. Therefore, the utilization of the available storage space for the country elevators in the state in 1954 was 52.09 per cent.

The country elevators in CRD 3 (Northeast Missouri) had storage capacity of 2,372,000 bushels, the highest of all crop reporting districts in the state in 1954. They utilized 50.80 per cent of the actual storage space for the 12-month period. The country elevators in CRD 9, bootheel area, were second in actual available storage space with $2,010,000$ bushels. They utilized 62.98 per cent of the available storage space which was the highest utilization of available storage space by country elevators in Missouri 
that year. The country elevators next to last in available storage space were those located in CRD 2 (North Central Missouri) who reported 402,000 bushels of actual available storage space with 52.24 per cent of it being utilized. They were eighth in actual available storage space but third in the state in the utilization of their actual available storage space. In CRD 8 (South Central Missouri) the country elevators had the least amount of available storage space, which was 116,000 bushels. The country elevators utilized 48.28 per cent of their available storage space in that Crop Reporting District (Table $\mathrm{XX}$ III) 
TABLE XXIII

PER CENT UTILIZATION OF AVAILABLE STORAGE SPACE OF COUNTRY ELEVATORS, BY CROP REPORTING DISTRICT, MISSOURI, 1954

\begin{tabular}{crlr}
\hline $\begin{array}{c}\text { Crop reporting } \\
\text { district }\end{array}$ & $\begin{array}{l}\text { Total } \\
\text { available } \\
\text { storage } \\
\text { space* }\end{array}$ & $\begin{array}{l}\text { Total } \\
\text { average } \\
\text { inventory* }\end{array}$ & $\begin{array}{l}\text { Per cent } \\
\text { utilization } \\
\text { of available } \\
\text { storage space* }\end{array}$ \\
\hline 1 & 1,520 & 697 & 45.86 \\
2 & 402 & 210 & 52.24 \\
3 & 2,372 & 1,205 & 50.80 \\
4 & 1,176 & 610 & 51.87 \\
5 & 720 & 296 & 41.11 \\
6 & 1,651 & 916 & 55.48 \\
7 & 1,585 & 758 & 47.82 \\
8 & 116 & 60 & 51.72 \\
9 & 11,552 & 6,018 & 62.98 \\
\hline State & & 1,266 & 52.09 \\
\hline
\end{tabular}

*In thousands of bushels

$* *$ Total average inventory as a per cent of available storage space. 


\section{CHAPTER VI \\ SHIPMENTS OF GRAIN}

During the period when the grain marketing system was developing, the railroad and river barge were the only methods of transporting so bulky a commodity as grain over distances so great as were represented by typical grain movements. This meant that country elevators were built on railroad lines so that they could effectively avail themselves of rail transportation. The development of highways and motor trucks has removed this restriction on transportation and increasing amounts of grain are moving from country elevators via truck. A part of this study was intended to measure the importance of truck transportation of grain in Missouri in 1954.

\section{METHOD OF TRANSPORTATION BY KIND OF GRAIN}

The 546 country elevators in 1954 handled an estimated $97,402,000$ bushels of corn, wheat, oats, barley, soybeans, and grain sorghums. Approximately 60,504,000 bushels, or about 62 per cent, of those grains were sold outside the immediate trade territory to processors and others. This study indicates that 78.30 per cent of those grains shipped to outside sources went by rail and 21.70 per cent went by motor truck. Rail transportation still 
remains the principal method of shipping grain by country elevators in Missouri.

Practically all of the wheat and soybeans handled by country elevators was shipped outside the immediate trade territory. Approximately 89 per cent of the wheat shipped and 85 per cent of the soybeans shipped were moved by rail. Only 10 to 14 per cent of these two grains were shipped by truck. The probable reason for the huge shipment of the cash grain to market by rail lies in the stop intransit privileges granted to rail shippers. Stop intransit is a provision whereby, after the grain is sold it can be unloaded, processed, reloaded, and shipped on to the fixed destination under a single shipping contract without an increase in the transportation rate. If the grain had been delivered by truck, the unloading and reloading would have been done under a separate contract. This would mean additional costs before the processed grain had reached its final destination.

In contrast to wheat and soybeans, a substantial portion of the feed grain that was moved outside the local trade territory was moved by truck. About one half of the corn so marketed, three fourths of the oats and grain sorghum, and all of the barley was transported from -

\section{${ }^{1}$ Calculations indicate 99.5 per cent.}


country elevators by trucks (Table XXIV). To properly interpret these comparatively high percentages it should be remembered that country elevators handled less than one half the amount of feed grains grown in Missouri that year and in turn marketed only about 25 per cent of their receipts of feed grain from farmers outside their local trade area. Nevertheless, truck transportation had grown to substantial importance in moving feed grains from surplus to deficit areas and directly to terminal elevators and processors.

II. AMOUNTS AND TYPES OF EACH GRAIN SHIPPED FOR COMMODITY CREDIT CORPORATION AND FOR STORAGE

From the data obtained in 1954 the country elevators located in six out of the nine crop reporting districts in Missouri shipped 1,115,000 bushels of wheat for Commodity Credit Corporation. This was approximately 4.23 per cent of the total wheat handled in the state.

The shipment of soybeans for Commodity Credit Corporation amounted to 112,000 bushels. The country elevators located in CRD 9 (Southeast Missouri) were the only elevators reporting shipment of soybeans for Commodity Credit Corporation. This amounted to 2.57 per cent of the total soybeans handled by the country elevators within that geographic location. 


\section{TABLE XXIV}

ESTIMATED PERCENTAGE OF TOTAL GRAIN HANDLED BY MISSOURI COUNTRY ELEVATORS THAT WAS SHIPPED OUTSIDE THE TRADE TERRITORY BY BUSHELS AND PERCENTAGE SHIPPED BY TYPE CARRIER, BY TYPE GRAIN, 1954

\begin{tabular}{|c|c|c|c|c|c|c|c|}
\hline Type grain & $\begin{array}{l}\text { Total* } \\
\text { grain } \\
\text { handled }\end{array}$ & $\begin{array}{l}\text { Total* } \\
\text { shipment } \\
\text { of grain } \\
\end{array}$ & $\begin{array}{l}\text { Per cent of } \\
\text { total. grain } \\
\text { handled shipped }\end{array}$ & $\begin{array}{l}\text { Bushels* } \\
\text { shipped } \\
\text { by rail }\end{array}$ & $\begin{array}{l}\text { Per cent } \\
\text { shipped } \\
\text { by rail }\end{array}$ & $\begin{array}{l}\text { Bushels* } \\
\text { shipped } \\
\text { by truck }\end{array}$ & $\begin{array}{l}\text { Per cent } \\
\text { shipped } \\
\text { by truck }\end{array}$ \\
\hline Corn & 38,021 & 10,223 & 26.89 & 4,957 & 48.49 & 5,266 & 51.51 \\
\hline Wheat & 26,352 & 26,326 & 99.90 & 23,515 & 89.32 & 2,811 & 10.68 \\
\hline Soybeans & 21,709 & 21,611 & 99.55 & 18,392 & 85.10 & 3,219 & 14.90 \\
\hline Oats & 8,863 & 1,798 & 20.29 & 410 & 22.80 & 1,388 & 77.20 \\
\hline Barley & 1,640 & 131 & 7.99 & & & 131 & 100.00 \\
\hline Grain sorghum & 817 & 415 & 50.80 & 103 & 24.82 & 312 & 75.18 \\
\hline State & 97,402 & 60,504 & 62.12 & 47,377 & 78.30 & 13,127 & 21.70 \\
\hline
\end{tabular}

*In thousands of bushels. 
In 1954 an estimated 560,000 bushels of corn were shipped for Commodity Credit Corporation from the bootheel area of Missouri (CRD 9). This was 14.18 per cent of the total corn handled in that particular area by country elevators.

The country elevators in 1954 did not ship appreciable amounts of grain to other elevators for storage. In CRD 7 (Southwest Missouri), the country elevators shipped 580,000 bushels of wheat, which was 12.17 per cent of the total wheat handled in that district, for storage at other elevators. There were 12,000 bushels of soybeans shipped from the country elevators in CRD 1 (Northwest Missouri). This was about one half of 1 per cent of the total soybeans handled by the country elevators in that district. For tables relating to further breakdown by grain and by crop reporting district see Appendix B, pages $108-112$.

\section{SHIPMENTS OF GRAIN BY COUNTRY ELEVATORS} AS RELATED TO LOADING CAPACITIES

The loading capacities of Missouri country elevators were estimated at 4,725,000 bushels per 10-hour work day. According to the data collected the country elevators shipped 60,504,000 bushels of corn, wheat, oats, soybeans, barley, and grain sorghum in 1954, of which wheat and 
soybeans made up almost 80 per cent of the total shipments. If the sample was representative, then it would have taken the 546 country elevators in the state about thirteen 10 -hour work days to load out the grain for shipment to outside sources. For example, in CRD 1 (Northwest Missouri) the country elevators had the highest loadingout capacity in the state, which was 847,000 bushels. At that rate, it would have taken them a little more than thirteen days to load all of the grain shipped to outside sources in that particular Crop Reporting District. The country elevators in CRD 8 (South Central Missouri) had the least loading capacity of any elevators in the state. They could load out at the rate of 120,000 bushels in a normal 10-hour work day. It would have taken those elevators only about six days to load all of the grain shipped (Table XXV). 
TABLE XXV

ESTIMATED TOTAL SHIPMENTS FROM COUNTRY ELEVATORS AND LOADING CAPACITIES BY CROP REPORTING DISTRICT, MISSOURI, 1954

\begin{tabular}{ccc}
\hline $\begin{array}{c}\text { Crop reporting } \\
\text { district }\end{array}$ & $\begin{array}{l}\text { Loading } \\
\text { capacity* }\end{array}$ & $\begin{array}{l}\text { Total } \\
\text { shipments }\end{array}$ \\
\hline 1 & 847 & 11,054 \\
2 & 338 & 7,491 \\
3 & 500 & 10,889 \\
4 & 625 & 7,596 \\
5 & 449 & 2,603 \\
6 & 639 & 4,779 \\
7 & 541 & 5,303 \\
8 & 120 & 740 \\
9 & 666 & 10,049 \\
\hline State & 4,725 & 60,504 \\
\hline
\end{tabular}

*Loading refers to normal loading capacity during a 10 hour day. 


\section{CHAPTER VII}

\section{SUMMARY}

This thesis is a presentation of the operations of country elevators in the state in 1954. The country elevators in Missouri handled approximately $97,402,000$ bushels of corn, grain sorghum, soybeans, wheat, barley, and oats, representing a total value of $\$ 180$ million.

Grain is produced seasonally and is subject to both short run and secular variation in production volume. The total production of Missouri grain varies from year to year depending upon weather conditions, fertilizer used, and government restrictions.

The purpose of this study was to evaluate the present handling, receiving, and storage facilities of country elevators and to develop information which will help operators in the remodeling, relocation, and rebuilding of their present facilities.

The combine, picker sheller, trucks, improved roads, and communication have all contributed toward the concentration of grain harvesting into a very short period during the year. Because of this phenomenon the handling of fertilizer, feeds, seeds, and other farm supplies have been added by the country elevator operator in order to develop a business which utilizes his facilities and labor 
the year round.

In 1954 over 50 per cent of Missouri country grain

elevators were owned by individuals who provided their own capital and usually operated their own elevators.

The estimated mean total capacity of the 546 country elevators in Missouri in 1954 was 30,478 bushels. The mean working space was 9,321 bushels, which left a mean available storage space of 21,157 bushels for the storage of grain.

In 1954 Missouri country elevators could have received the $73,847,000$ bushels of corn, wheat, soybeans, oats, barley, and grain sorghum from farmers in fifteen 10-hour work days. This indicates that Missouri country elevators did have sufficient receiving capacity to receive the grain sold to them by the producers.

The country elevators received 23,555,000 bushels of feed grain, which are corn, oats, barley, and grain sorghum from grain handlers. The grain handlers shipped approximately 80 per cent of the feed grains to the country elevators by truck and 20 per cent by rail.

Approximately 37.88 per cent of the total grain handled by country elevators was resold locally as feed or seed. The remaining 62.12 per cent $(60,504,000$ bushels) was shipped to outside sources such as terminal or other elevators, processors, and for Commodity Credit 
Corporation. The $60,504,000$ bushels of grain shipped in 1954 could have been loaded out by the country elevators in approximately thirteen 10-hour work days. This would indicate that Missouri country elevators in 1954 did have enough equipment to load out the grain that they shipped to outside sources. Rail was the chief mode of transportation used by country elevators to ship grain to outside sources. The country elevators in the state in 1954 had an estimated total available storage space of $11,552,000$ bushels, which was approximately equal to 15 per cent of the total amount of grain received direct from producers. The utilization of Missouri country elevators' available storage space for a 12 -month period was 52.09 per cent. However, the storage of grain during peak inventory deviated from a high of $7,871,000$ bushels of wheat to a low of 311,000 bushels for grain sorghum. The country elevators do not store appreciable amounts of grain for terminal elevators or processors. Many of the country elevators do not have enough storage facilities to store the different types of grain received from the producers for any length of time. Therefore, much of the grain received during the peak marketing period by the country elevator is shipped directly to the terminal market or processors as soon as a truck load or a railcar accumulates Many elevators do not have enough storage space and bins to 
blend grain so they depend upon the terminal elevators to perform this service.

Soybeans and wheat are Missouri's leading cash

crops. The country elevators in the state received

48,061,000 bushels of those grains from farmers. In 1954

the country elevators shipped 89.32 per cent of the wheat

received and 85.10 per cent of the soybeans to processors

by rail. This was done to take advantage of the stop intransit privilege granted by railroads. The intransit privilege allows the processor to unload, process, reload, and ship the processed grain to the final destination without a change in freight rate. 


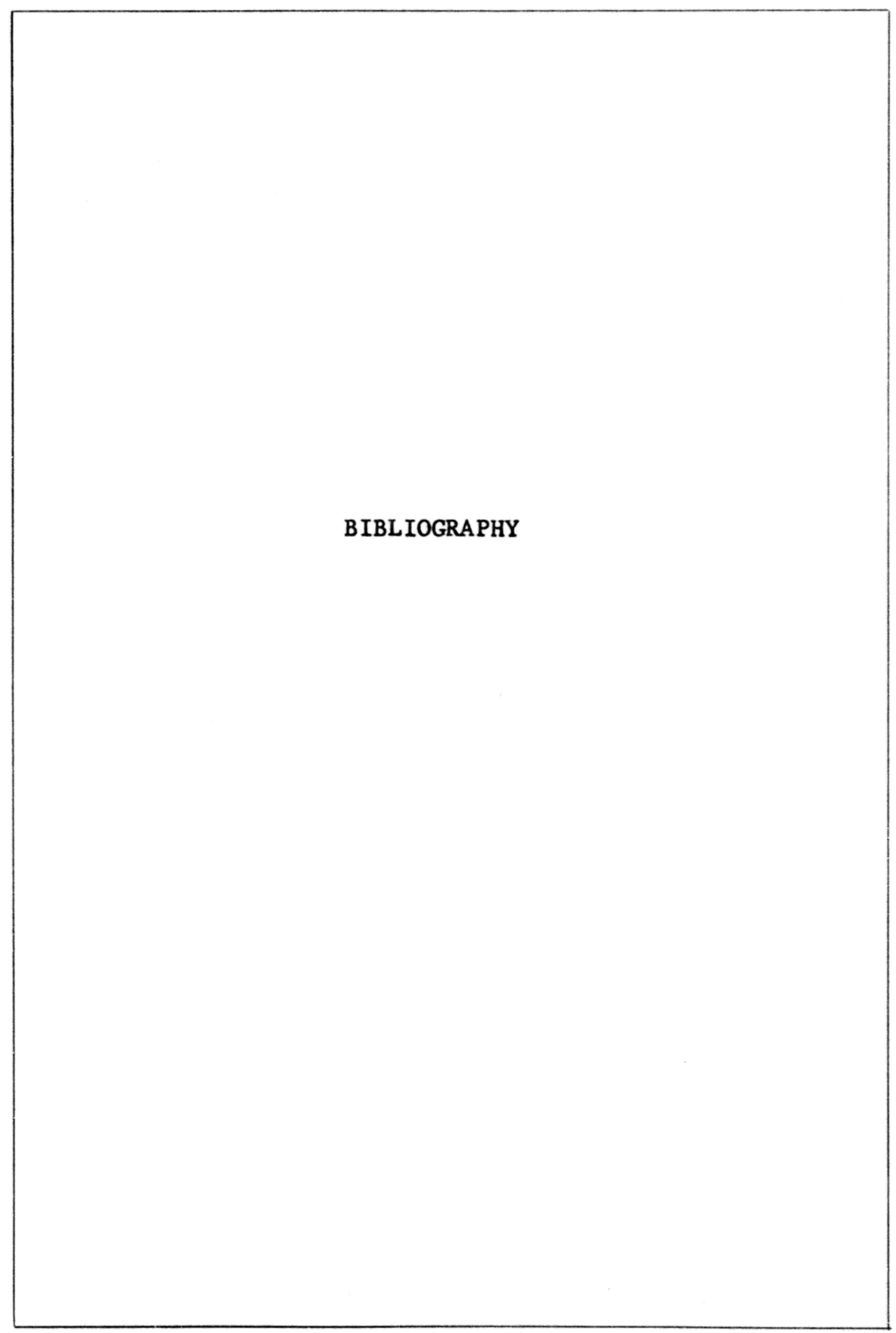




\section{B IBLIOGRAPHY}

Farre11, Kenneth R., "Economics of Grain Storage at the Terminal Elevator and Wholesale Processor Level in Iowa." Unpublished Master's thesis, Iowa State College, Ames, Iowa, 1955.

Harston, Clive R., Marketing High Protein Wheat in the Northern Great Plains, Montana State College Agricultural Experiment Station Bulletin No. 527, January, 1957, pp. 112.

Hinrichs, A. F., An Economic Analysis of Local Grain Elevators in Indiana, Indiana Agricultural Experiment station BuIletin No. 403, July, 1935, pp. 32.

Missouri Farm Census by Counties, 1954. Missouri State Department of Agriculture, Jefferson City, Missouri, pp. 18.

Malott, D. W., and others, Grain and Its Marketing, Prepared for Grain Exchange Institute, Chicago, I11inois, 1954.

Moore, Dale, "Marketing Grain Through Country Elevators in Missouri." Unpublished Master's thesis, University of Missouri, Columbia, Missouri, 1952.

Norton, L. J., Business Policies of Country Grain Elevators. Ilinois Agricultural Experiment Station BuIletin No. 477, April, 1941, pp. 31 .

Richey, P. S., and Johnson, T. D., Factors to Be Considered in Locating, Planning, and operating Country Elevators, United States Department of Agriculture, Production and Marketing Administration, Marketing Research Report No. 23, June, 1952, pp. 94.

Snedecor, George W., Statistical Methods. Fourth edition, Ames: The Iowa CoIlege Press, 1950.

Temple, Norman R., "Characteristics of Country Elevators in Missouri as They Relate to Grain Marketing," Unpublished Master's thesis, University of Missouri, Columbia, Missouri, 1955.

Tompkin, R. D., and Newberg, R. R., Problems in Marketing South Dakota Grain, South Dakota AgricuIturaI 
83

Experiment Station, Agricultural Economics Pamphlet No. 62, June, 1955, pp. 72 .

The Consolidated Grain Milling Catalogs. Fifth edition, Chicago: American Miller, Copyright, 1941 National Miller Publications, Inc., 1941.

United States Department of Agriculture. "United States Crop Summary as of August 1, 1955," Crop Production, Agricultural Marketing Service, 1955.

United States Department of Agriculture. "United States Crop Summary as of August 1, 1957," Crop Production, Agricultural Marketing Service, 1957 . 


\section{APPENDIX A \\ QUESTIONNAIRE USED IN COLLECTING \\ BASIC DATA}




\section{Schedule NCM-10-B-2 -- Country Elevators}

1. Location: a. Town b. County

c. Crop Reporting District d. State

2. a. Elevator operated by

b. Location of home office

c. Does this company own the elevator? Yes__ No__ If no, who does?

d. Do you have any marketing agreement or purchasing agreement with another company? Yes__ No___ If yes, describe

e. Do you have any other type of financial or marketing arrangement with another company? Yes_ No___ If yes, describe

3. Type of organization: Cooperative___, Independent__, Line___, or Branch elevator

4. Storage capacity:

a. Licensed bulk storage capacity

b. Storage capacity required as working space bushels

c. Total actual bulk capacity of elevator

d. Actual bulk capacity available for storage and inventories bushels bushels bushels

5. a. What railroads is the elevator on?

b. If none, how far do you haul to a rail point?

6. a. Is any processing done at this elevator? Yes No

b. Annuel volume:

Volume

Units

oilseed processing flour milling

feed manufacturing

custom mixing

seed nrocessing

other

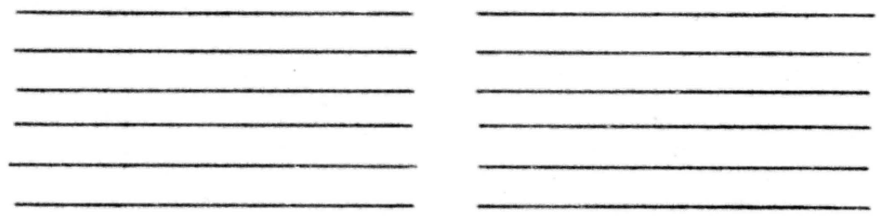

7. Functions performed at elevator: (check those which apply) loading on rail loading on truck loading on water receiving by rail trucking from farm to elevator long distance hauling

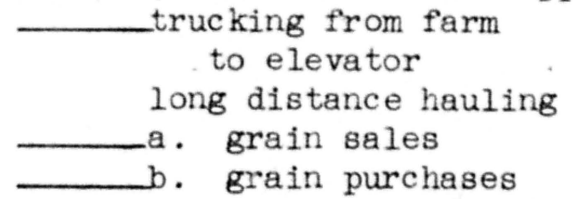

b. grain purchases storage for processors storage for farmers storage for $\mathrm{CCC}$ artificial drying other

8. Under typical conditions how many bushels can you -

a. Receive in a 10-hour day?

b. Load in a 10-hour day? 
9. Description of Major Grain Facilities and Equipment

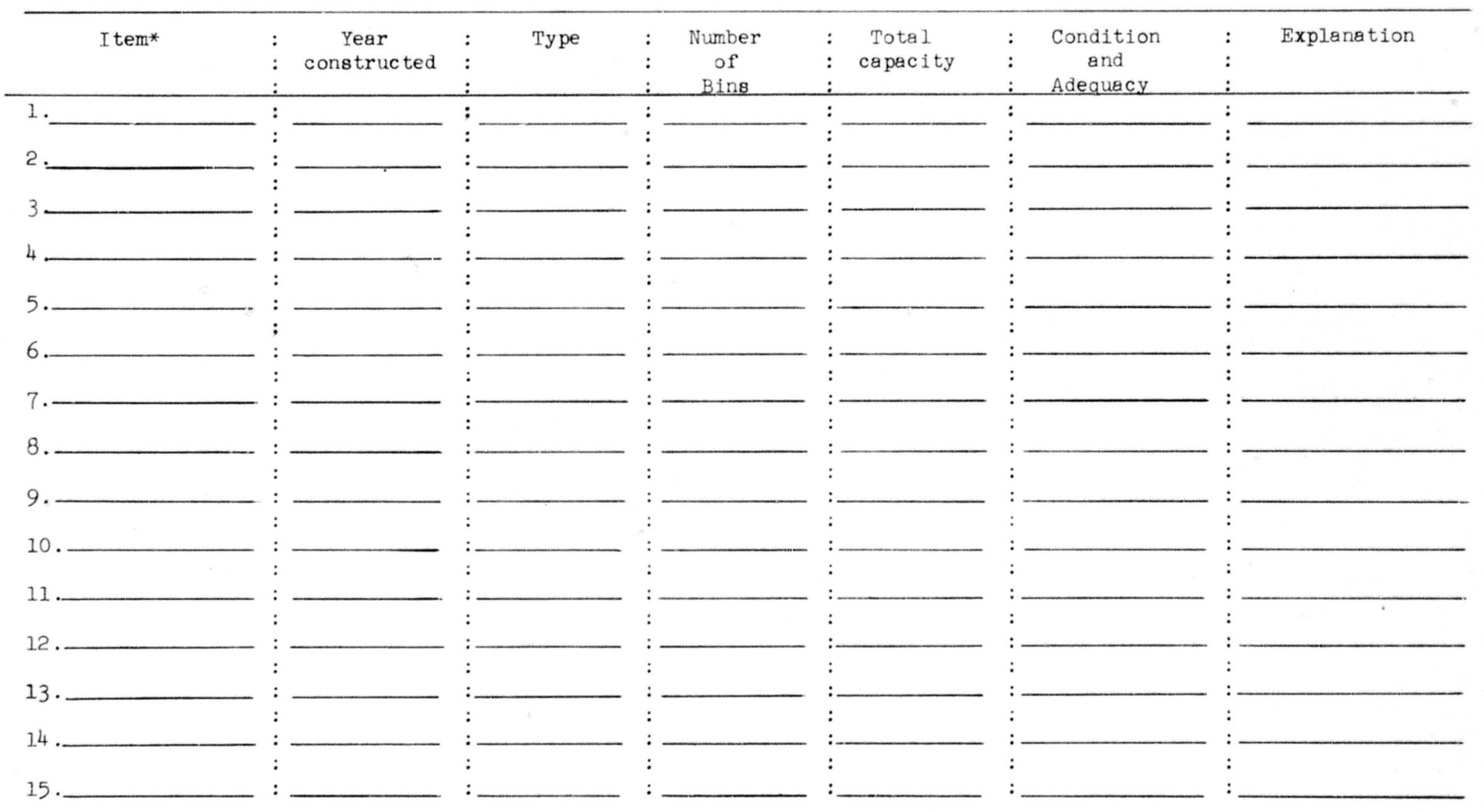

* Storage facilities, permanent receiving and loading equipment, scales, drier, mill, etc. 
10. Estimated Volume of Grain Received

\section{TYPE OF RECEIPTS}

A . RECEIPTS

1. Bushels direct from farmers (including deliveries to $\mathrm{CCC}$ )

2.* Bushels from grain handlers by rail

a. Major origins of (1. origin rail receipts and bushels bushels from each(2. origin

bushels (3. origin

( bushels

3.*. Bushels from grain handlers

as by truck

a. Major origins of (1. origin truck receipts \& ( bushels bushels from each(2. origin bushels (3. origin bushels

4.* Total bushels from grain handlers

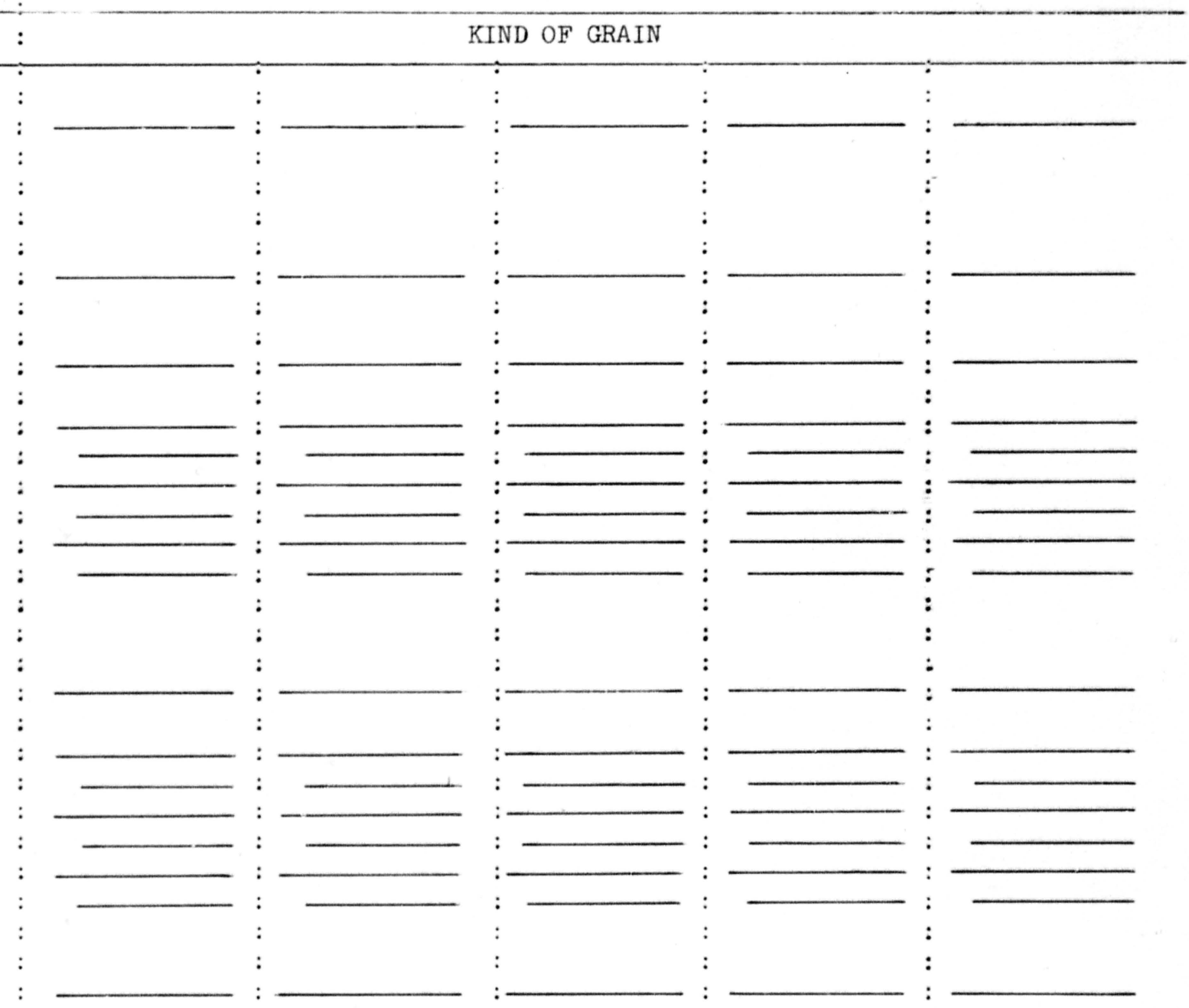

* Include receipts of CCC grain, both purchases and handling 
11. Estimated Volume of Grain Shipped

\section{TYPE OF SHIPMENTS}

B. SHIPMENTS AND SALES

1. Total bushels merchandised

2. Bushels sold locally

3. Bushels shipped for storage

4. Bushels shipped for $\mathrm{CCC}$

5. Total bushels shipped by rail

a. Major destinations (1. dest. of rail shipments ( bu.

\& bushels to each (2. dest:

( bu.

(3. dest

bu.

(4. dest.

6. Total bushels shipped by truck a. Major destinations of truck shipments \& bushels to each

(1. dest.
(2. dest.
(2) bu.
(3. dest.
(3) bu.
(4. dest.
( bu.

7. Total bushels shipped by water a. Major destinations of water shipments \& bushels to each

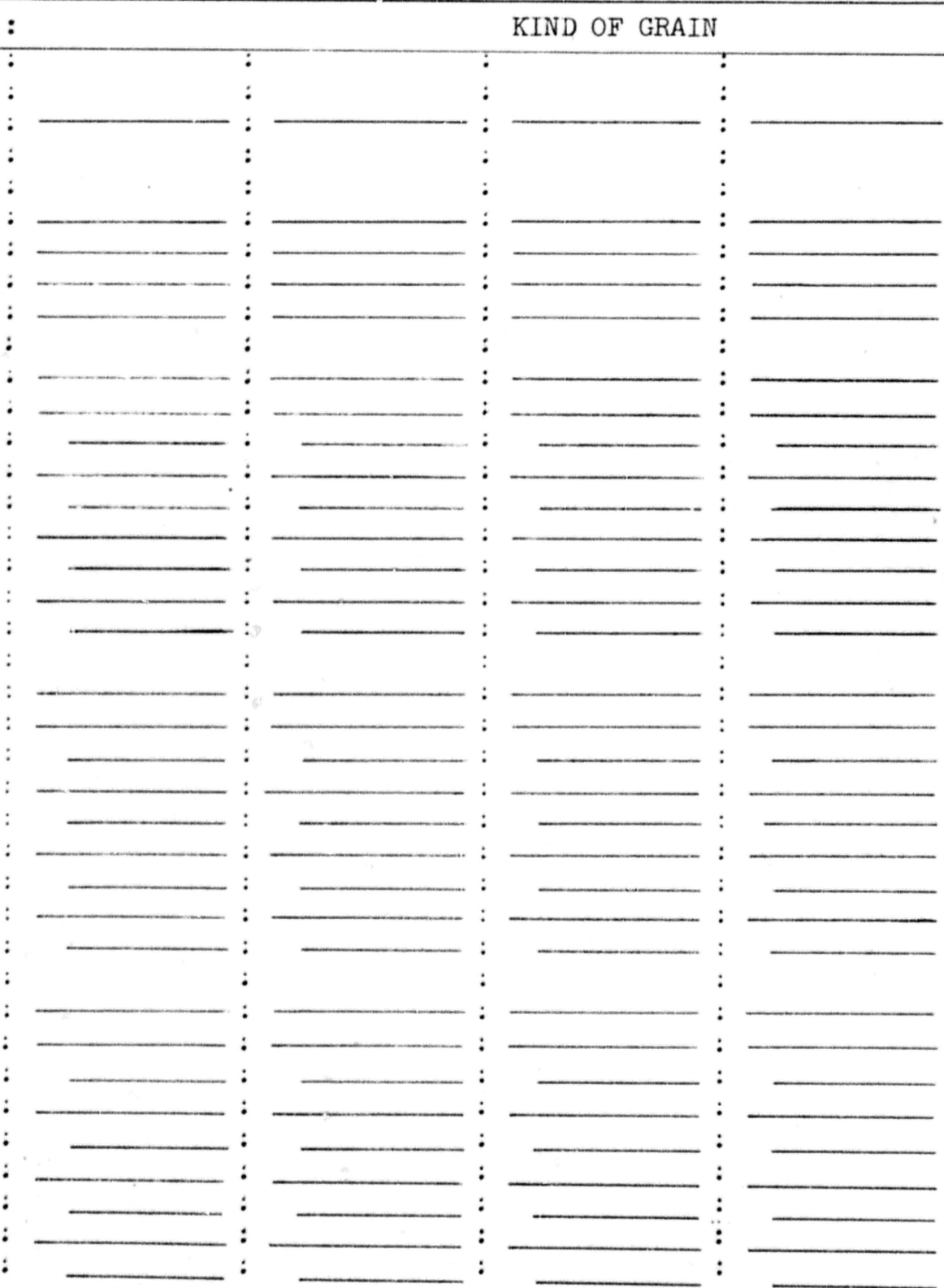

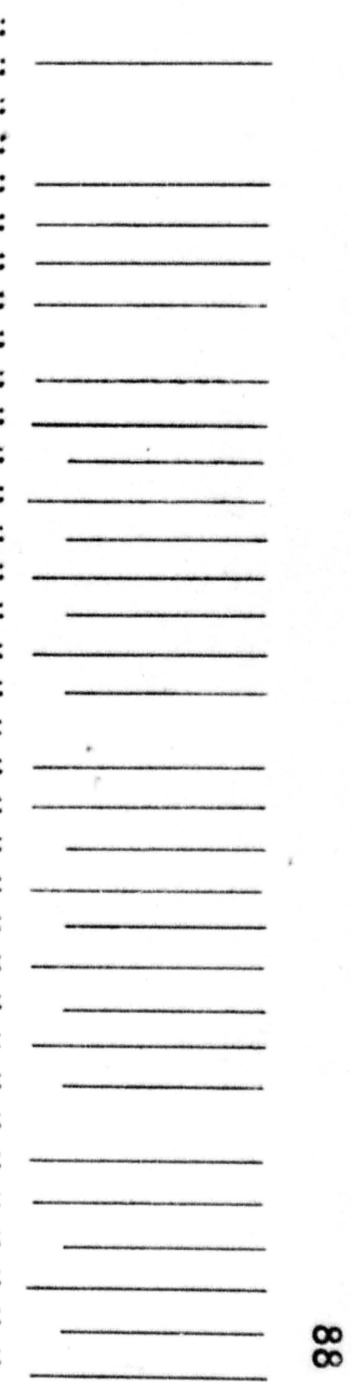
(4. dest. bu. 
12. Estimated Bushels of Grain Inventories and Storage

GRAIN STORAGE AND INVENTORIES

1. Bushels on hand at peak of:
a. Own inventory
b. Storage for farmers
c. Storage for processors
d. Storage for $\mathrm{CCC}$
e. Other storage
f. Total storage and inventories at peak

2. Average number of bushels on hand of:
a. Own inventory .
b. Storage for farmers
c. Storage for processors
d. Storage for CCC
e. Other storage
f. Total average number of bushels on hand

\section{KIND OF GRAIN}

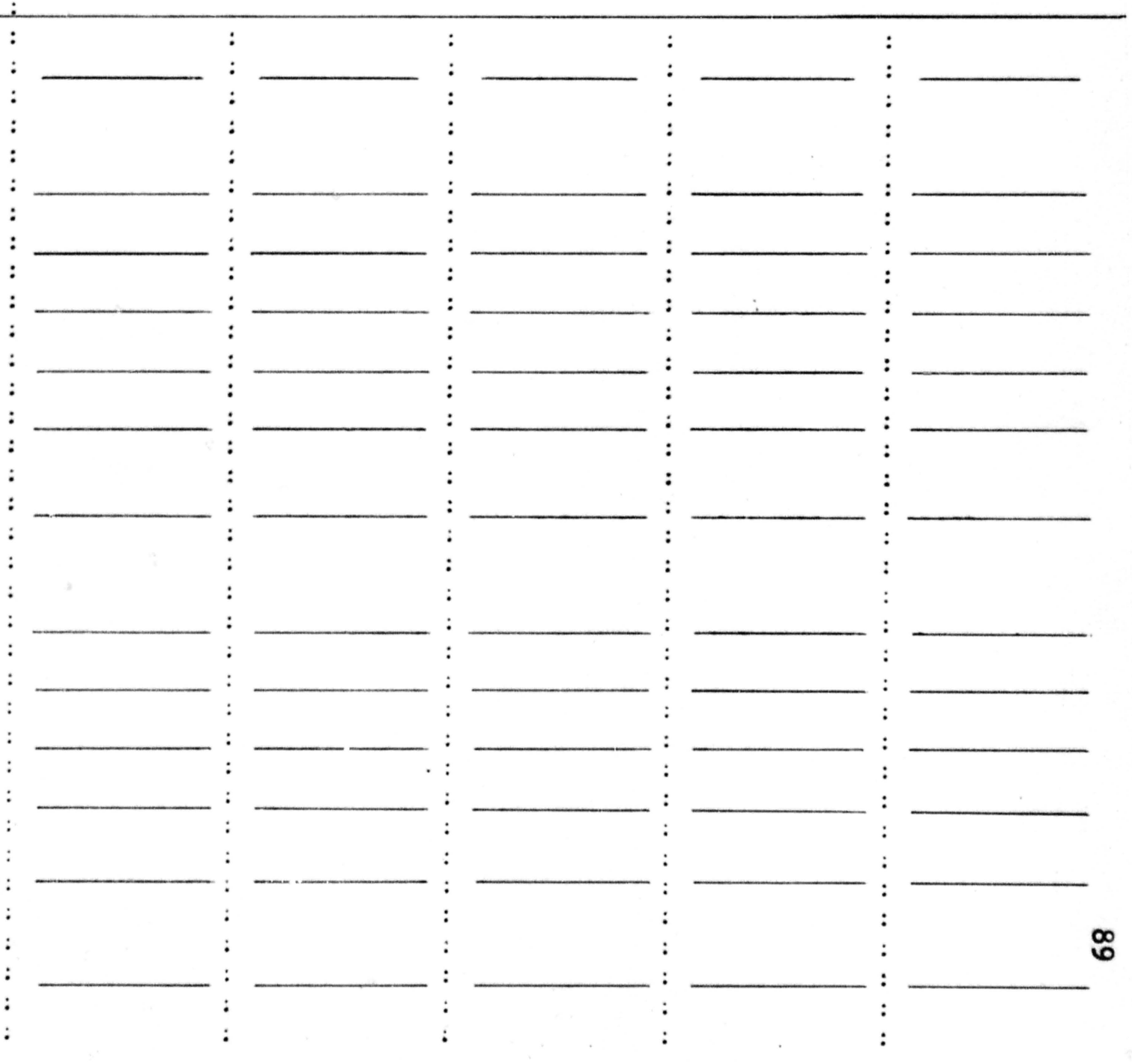


APPENDIX B

TABLES OF BASIC DATA 
TABLE XXVI

ESTIMATED RECEIPTS OF WHEAT AND SOYBEANS AT COUNTRY ELEVATORS, BY CROP REPORTING DISTRICT, MISSOURI, 1954

\begin{tabular}{|c|c|c|c|c|}
\hline \multirow{2}{*}{$\begin{array}{l}\text { Crop } \\
\text { reporting } \\
\text { district }\end{array}$} & \multicolumn{4}{|c|}{ Estimated receipts* } \\
\hline & Total & From farmers & Total & From farmers \\
\hline & \multicolumn{2}{|c|}{ Wheat } & \multicolumn{2}{|c|}{ Soybeans } \\
\hline 1 & 4,159 & 4,159 & 2,406 & 2,406 \\
\hline 2 & 1,686 & 1,686 & 4,960 & 4,960 \\
\hline 3 & 2,994 & 2,994 & 7,061 & 7,061 \\
\hline 4 & 4,492 & 4,492 & 1,176 & 1,176 \\
\hline 5 & 1,691 & 1,691 & $76 \dot{4}$ & 764 \\
\hline 6 & 4,134 & 4,134 & 632 & 632 \\
\hline 7 & 4,765 & 4,765 & 306 & 306 \\
\hline 8 & 499 & 499 & 39 & 39 \\
\hline 9 & 1,932 & 1,932 & 4,365 & 4,365 \\
\hline State & 26,352 & 26,352 & 21,709 & 21,709 \\
\hline
\end{tabular}

*In thousands of bushels. 
TABLE XXVII

ESTIMATED RECEIPTS OF CORN AT COUNTRY ELEVATORS, BY CROP REPORTING DISTRICT, MISSOURI, 1954

\begin{tabular}{|cccccc}
\hline \hline \multirow{2}{*}{$\begin{array}{c}\text { Crop } \\
\text { reporting } \\
\text { district }\end{array}$} & Total & From farmers & Total & By rail & By truck \\
\cline { 2 - 6 } & 9,442 & 6,820 & 2,622 & 2,622 \\
2 & 1,822 & 1,396 & 426 & 426 \\
3 & 1,470 & 1,372 & 98 & 98 \\
4 & 4,527 & 1,998 & 2,529 & 25 & 2,504 \\
5 & 2,495 & 424 & 2,071 & 2,071 \\
6 & 5,734 & 2,832 & 2,902 & 52 & 2,850 \\
7 & 7,177 & 271 & 6,906 & 2,165 & 4,741 \\
8 & 1,406 & 275 & 1,131 & 280 & 851 \\
9 & 3,948 & 3,892 & 56 & & 56 \\
\hline State & 38,021 & 19,280 & 18,741 & 2,522 & 16,219 \\
\hline \hline
\end{tabular}

*In thousands of bushels. 
TABLE XXVIII

ESTIMATED RECEIPTS OF OATS AT COUNTRY ELEVATORS, BY CROP REPORTING DISTRICT, MISSOURI, 1954

\begin{tabular}{|c|c|c|c|c|c|}
\hline \multirow{3}{*}{$\begin{array}{l}\text { Crop } \\
\text { reporting } \\
\text { district }\end{array}$} & \multicolumn{5}{|c|}{ Estimated receipts* } \\
\hline & \multirow[b]{2}{*}{ Total } & \multirow[b]{2}{*}{ From farmers } & \multicolumn{3}{|c|}{ From handlers } \\
\hline & & & Total & By rail & By truck \\
\hline 1 & 870 & 632 & 238 & & 238 \\
\hline 2 & 328 & 274 & 54 & & 54 \\
\hline 3 & 1,019 & 505 & 514 & & 514 \\
\hline 4 & 2,563 & 1,756 & 807 & & 807 \\
\hline 5 & 951 & 483 & 468 & 59 & 409 \\
\hline 6 & 755 & 271 & 484 & 400 & 84 \\
\hline 7 & 1,648 & 942 & 706 & 595 & 111 \\
\hline 8 & 611 & 86 & 525 & 138 & 387 \\
\hline 9 & 118 & 118 & & & \\
\hline State & 8,863 & 5,067 & 3,796 & 1,192 & 2,604 \\
\hline
\end{tabular}

*In thousands of bushels. 
TABLE XXIX

ESTIMATED RECEIPTS OF BARLEY AT COUNTRY ELEVATORS, BY CROP REPORTING DISTRICT, MISSOURI, 1954

\begin{tabular}{cccccc}
\hline \hline \multirow{2}{*}{$\begin{array}{c}\text { Crop } \\
\text { reporting } \\
\text { district }\end{array}$} & Total & From farmers & Total & By rail & By truck \\
\cline { 4 - 6 } 1 & 290 & 41 & 249 & 249 & \\
\cline { 4 - 6 } 3 & 176 & 24 & 152 & 152 & \\
4 & 330 & 217 & 113 & 49 & 64 \\
5 & 109 & 30 & 79 & 79 & \\
6 & 187 & 97 & 90 & 90 & 48 \\
7 & 391 & 343 & 48 & & \\
8 & 34 & 34 & & & \\
9 & 123 & 123 & & & \\
\hline
\end{tabular}

*In thousands of bushels. 
TABLE XXX

ESTIMATED RECEIPTS OF GRAIN SORGHUM AT COUNTRY ELEVATORS, BY CROP REPORTING DISTRICT, MISSOURI, 1954

\begin{tabular}{|c|c|c|c|c|c|}
\hline \multirow{3}{*}{$\begin{array}{l}\text { Crop } \\
\text { reporting } \\
\text { district }\end{array}$} & \multicolumn{5}{|c|}{ Estimated receipts* } \\
\hline & \multirow[b]{2}{*}{ Total } & \multirow[b]{2}{*}{ From farmers } & \multicolumn{3}{|c|}{ From handlers } \\
\hline & & & Total & By rail & By truck \\
\hline 1 & 47 & 47 & & & \\
\hline 2 & 139 & 139 & & & \\
\hline 4 & 256 & 222 & 34 & & 34 \\
\hline 5 & 109 & 99 & 10 & & 10 \\
\hline 7 & 227 & 19 & 208 & 169 & 39 \\
\hline 8 & 39 & 4 & 35 & 26 & 9 \\
\hline State & 817 & 530 & 287 & 195 & 92 \\
\hline
\end{tabular}

*In thousands of bushels. 


\begin{tabular}{|c|c|c|c|c|c|c|}
\hline \multirow[b]{2}{*}{$\begin{array}{l}\text { Crop } \\
\text { reporting } \\
\text { district }\end{array}$} & \multicolumn{6}{|c|}{$\begin{array}{c}\text { ESTIMATED VOLUME* OF WHEAT HANDLED AT COUNTY ELEVATORS BY CROP } \\
\text { REPORTING DISTRICT, MISSOURI, } 1954\end{array}$} \\
\hline & $\begin{array}{l}\text { Total } \\
\text { handled }\end{array}$ & Total & $\begin{array}{l}\text { chandisec } \\
\text { Sold } \\
\text { locally }\end{array}$ & $\begin{array}{l}\begin{array}{l}\text { Sold } \\
\text { outside }\end{array} \\
\end{array}$ & $\begin{array}{l}\text { Shipped } \\
\text { for storage }\end{array}$ & $\begin{array}{l}\text { Shipped } \\
\text { for CCC }\end{array}$ \\
\hline 1 & 4,159 & 4,107 & & 4,107 & & 52 \\
\hline 2 & 1,686 & 1,686 & & 1,686 & & \\
\hline 3 & 2,994 & 2,504 & & 2,504 & & 490 \\
\hline 4 & 4,492 & 4,295 & & 4,295 & & 197 \\
\hline 5 & 1,691 & 1,617 & & 1,617 & & 74 \\
\hline 6 & 4,134 & 4,134 & 13 & 4,121 & & \\
\hline 7 & 4,765 & 4,185 & & 4,185 & 580 & \\
\hline 8 & 499 & 477 & 13 & 464 & & 22 \\
\hline 9 & 1,932 & 1,652 & & 1,652 & & 280 \\
\hline State & 26,352 & 24,657 & 26 & 24,631 & 580 & 1,115 \\
\hline
\end{tabular}


TABLE XXXII

ESTIMATED VOLUME* OF SOYBEANS HANDLED AT COUNTRY ELEVATORS BY CROP REPORTING DISTRICT, MISSOURI, 1954

\begin{tabular}{|c|c|c|c|c|c|c|}
\hline \multirow{2}{*}{$\begin{array}{l}\text { lrop } \\
\text { reporting } \\
\text { district }\end{array}$} & \multirow[b]{2}{*}{$\begin{array}{l}\text { Total } \\
\text { handled }\end{array}$} & \multicolumn{3}{|c|}{ Merchandised } & \multirow[b]{2}{*}{$\begin{array}{l}\text { Shipped } \\
\text { for storage }\end{array}$} & \multirow[b]{2}{*}{$\begin{array}{l}\text { Shipped } \\
\text { for CCC }\end{array}$} \\
\hline & & Total & $\begin{array}{l}\text { Sold } \\
\text { loca11y }\end{array}$ & $\begin{array}{l}\text { Sold } \\
\text { outside }\end{array}$ & & \\
\hline 1 & 2,406 & 2,394 & 87 & 2,307 & 12 & \\
\hline 2 & 4,960 & 4,960 & & 4,960 & & \\
\hline 3 & 7,061 & 7,061 & & 7,061 & & \\
\hline 4 & 1,176 & 1,176 & & 1,176 & & \\
\hline 5 & 764 & 764 & & 764 & & \\
\hline 6 & 632 & 632 & & 632 & & \\
\hline 7 & 306 & 306 & & 306 & & \\
\hline 8 & 39 & 39 & & 39 & & \\
\hline 9 & 4,365 & 4,253 & 11 & 4,242 & & 112 \\
\hline State & 21,709 & 21,585 & 98 & 21,487 & 12 & 112 \\
\hline
\end{tabular}




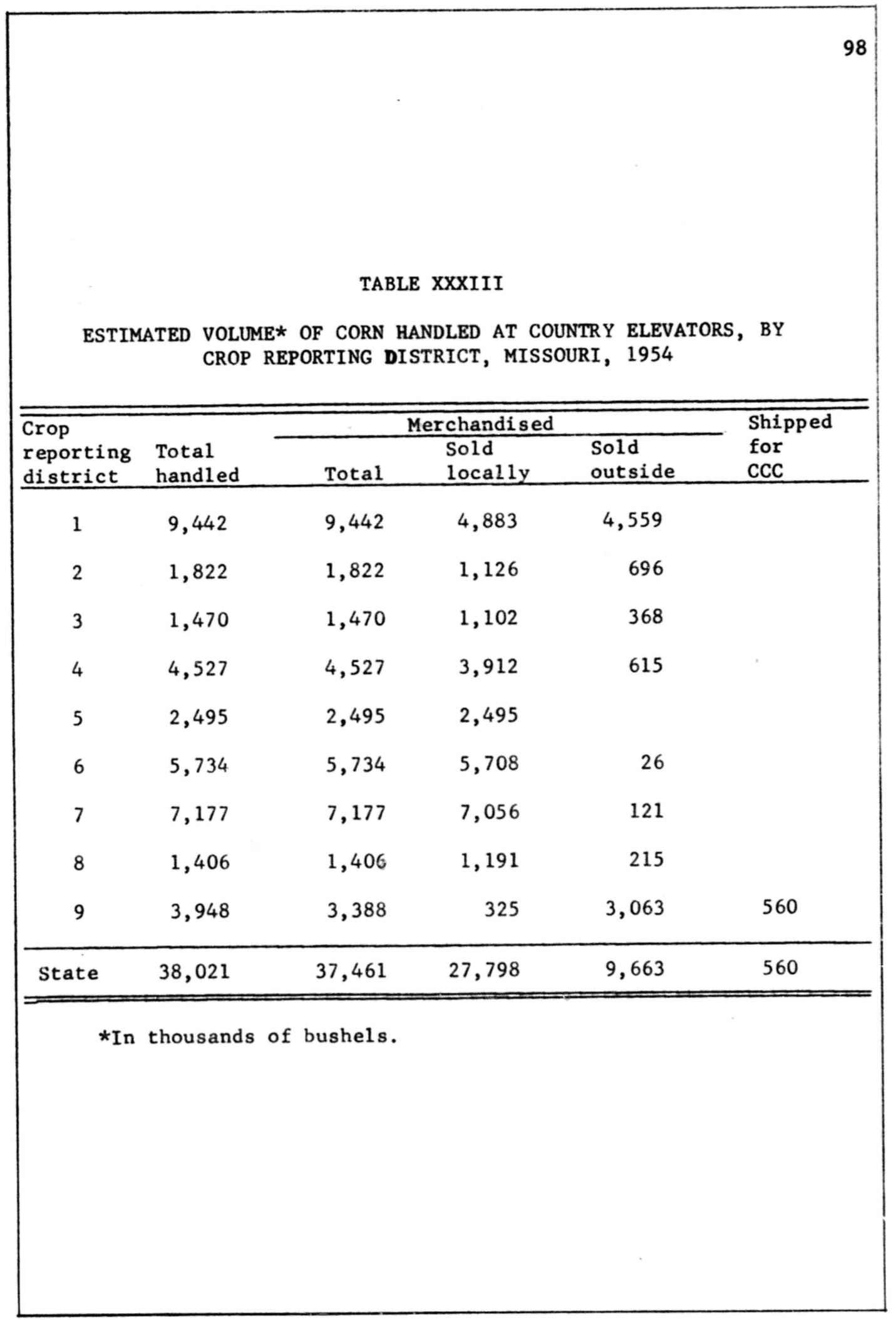




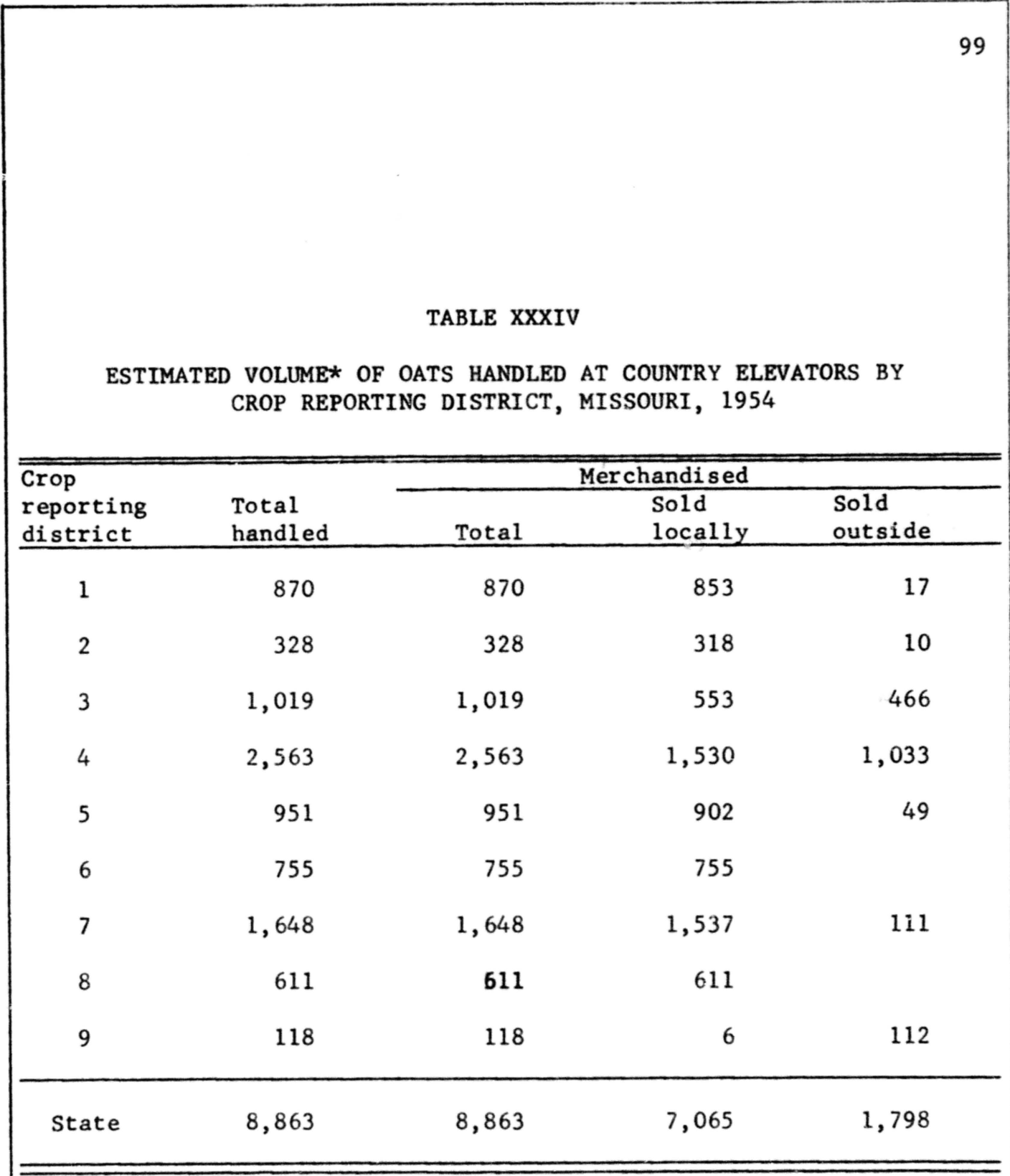

*In thousands of bushels. 


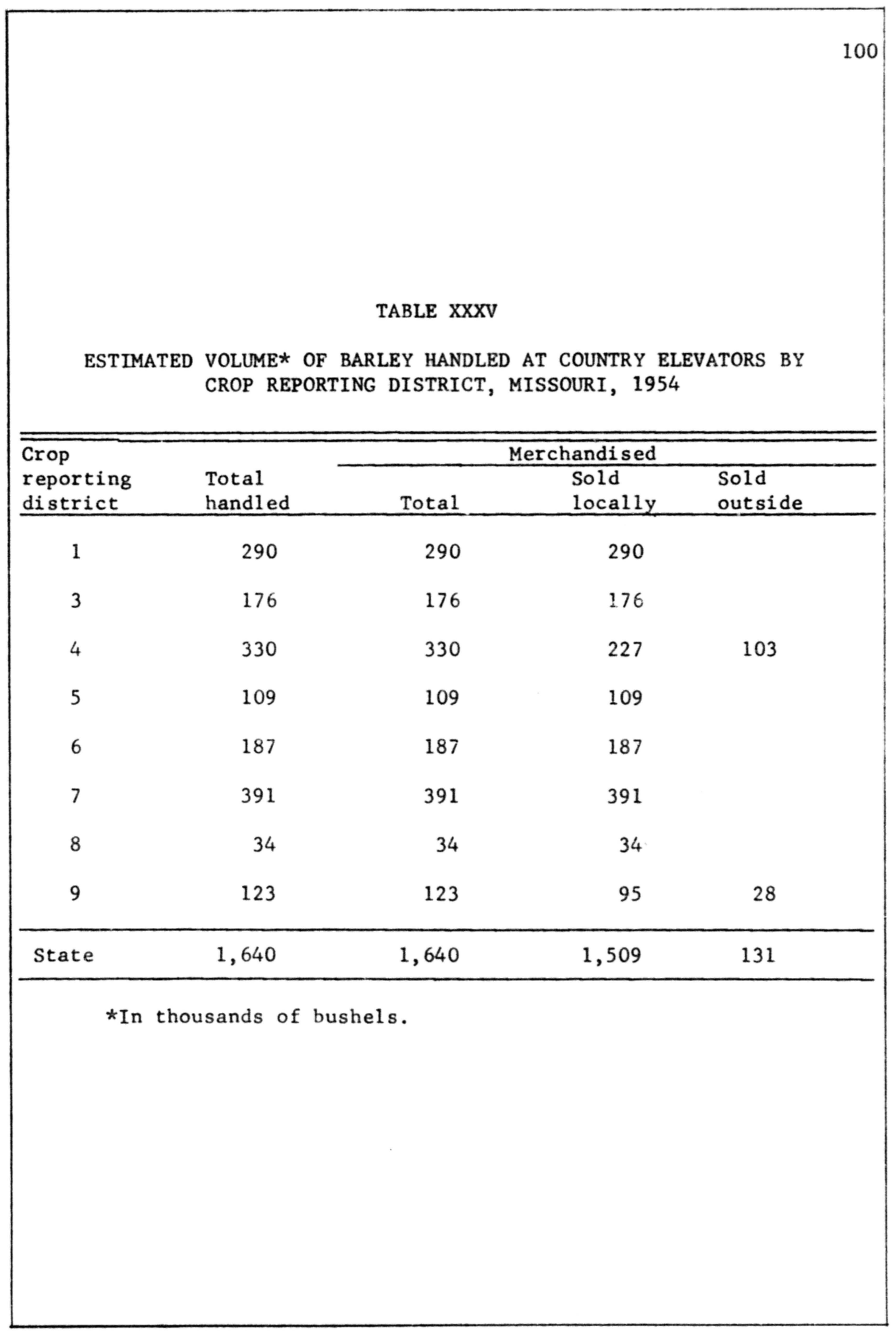




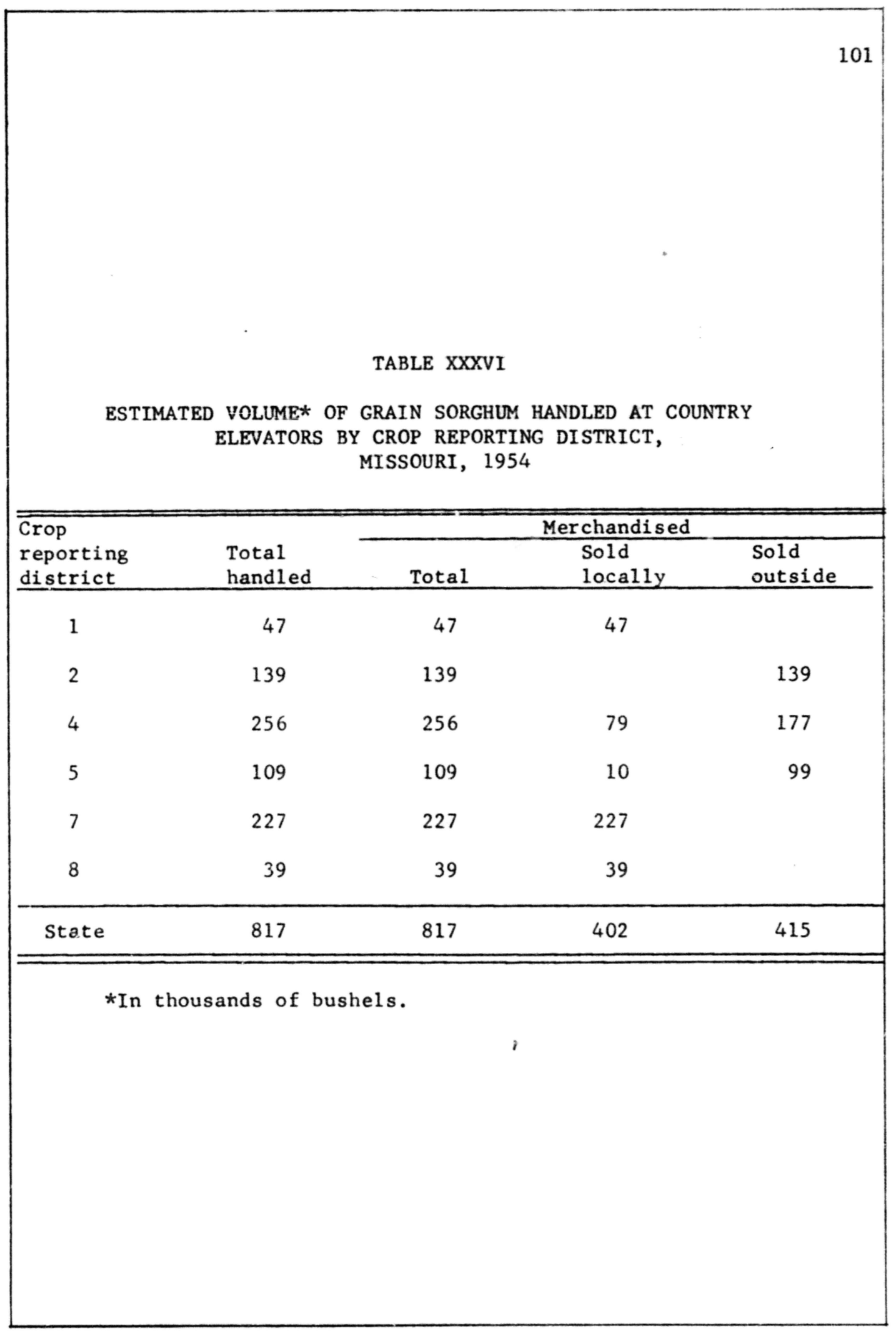


TABLE XXXVII

ESTIMATED PEAK STORAGE INVENTORY OF WHEAT AND CORN AT COUNTRY ELEVATORS, BY CROP REPORTING DISTRICT, MISSOURI, 1954

\begin{tabular}{|c|c|c|c|c|c|c|c|c|}
\hline \multirow{2}{*}{$\begin{array}{l}\text { Crop } \\
\text { reporting } \\
\text { district } \\
\end{array}$} & \multicolumn{8}{|c|}{ Estimated peak inventory* } \\
\hline & Total & Own & Farmers & $\mathrm{CCC}$ & Total & Own & Farmers & $\mathrm{CCC}$ \\
\hline & \multicolumn{4}{|c|}{ Wheat } & \multicolumn{4}{|c|}{ Corn } \\
\hline 1 & 1,207 & 1,079 & 128 & & 731 & 719 & 12 & \\
\hline 2 & 309 & 289 & 20 & & 225 & 225 & & \\
\hline 3 & 1,000 & 1,000 & & & 294 & 294 & & \\
\hline 4 & 1,069 & 805 & 264 & & 669 & 571 & 98 & \\
\hline 5 & 542 & 493 & 49 & & 212 & 212 & & \\
\hline 6 & 1,290 & 1,290 & & & 587 & 587 & & \\
\hline 7 & 1,421 & 802 & 474 & 145 & 1,073 & 1,073 & & \\
\hline 8 & 47 & 47 & & & 69 & 69 & & \\
\hline 9 & 986 & 706 & 140 & 140 & 1,187 & 1,086 & & 101 \\
\hline State & 7,871 & 6,511 & 1,075 & 285 & 5,047 & 4,836 & 110 & 101 \\
\hline
\end{tabular}

*In thousands of bushels. 
TABLE XXXVIII

ESTIMATED PEAK STORAGE INVENTORY OF SOYBEANS AT COUNTRY ELEVATORS, BY CROP REPORTING DISTRICT, MISSOURI, 1954

\begin{tabular}{|c|c|c|c|}
\hline \multirow{2}{*}{$\begin{array}{l}\text { Crop } \\
\text { reporting } \\
\text { district }\end{array}$} & \multicolumn{3}{|c|}{ Estimated peak inventory* } \\
\hline & Total & Own & Farmers \\
\hline 1 & 708 & 708 & \\
\hline 2 & 359 & 359 & \\
\hline 3 & 2,176 & 2,176 & \\
\hline 4 & 468 & 438 & 30 \\
\hline 5 & 138 & 138 & \\
\hline 6 & 181 & 181 & \\
\hline 7 & 222 & 222 & \\
\hline 8 & 13 & 13 & \\
\hline 9 & 1,333 & 1,221 & 112 \\
\hline State & 5,598 & 5,456 & 142 \\
\hline
\end{tabular}

*In thousands of bushels. 


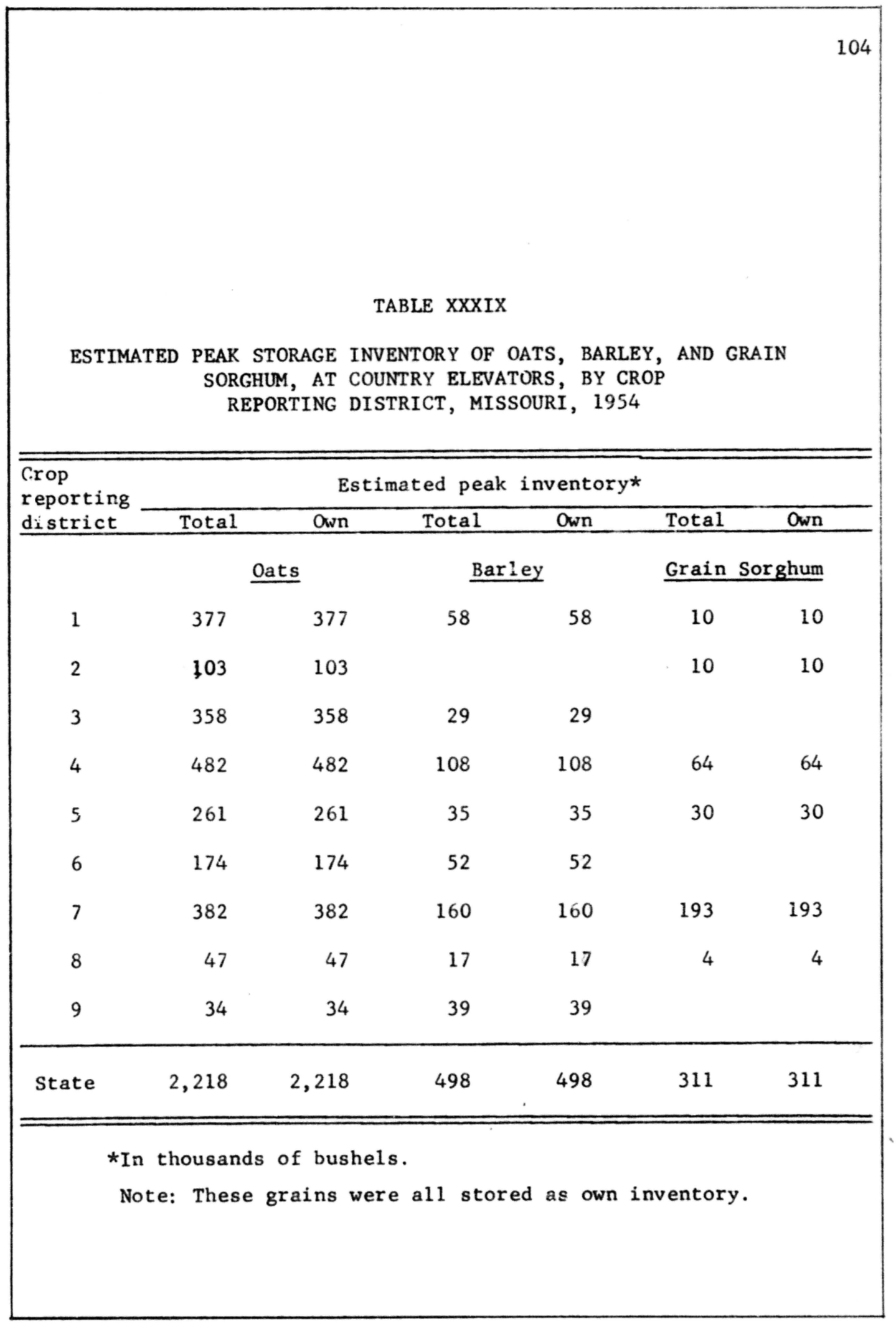




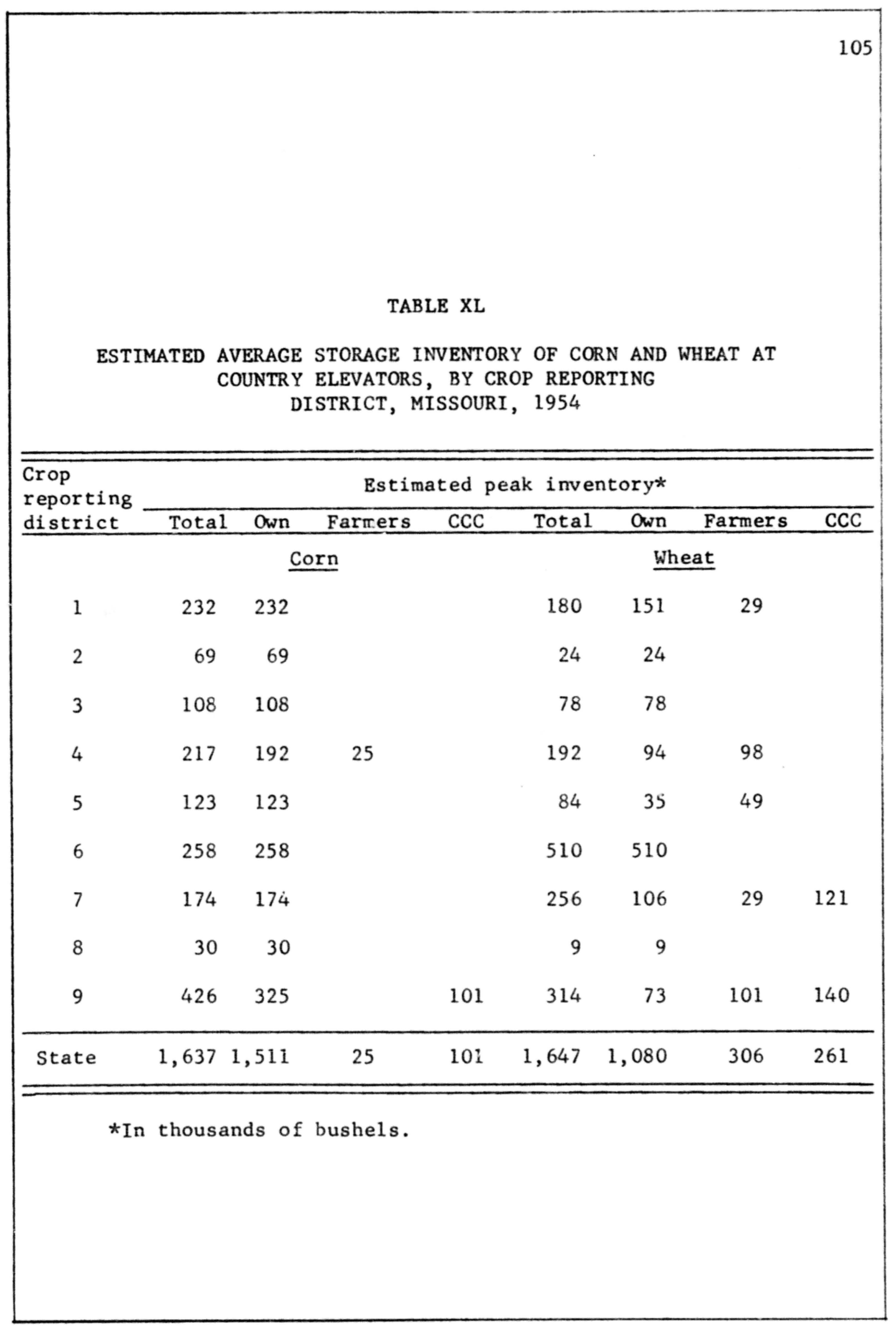




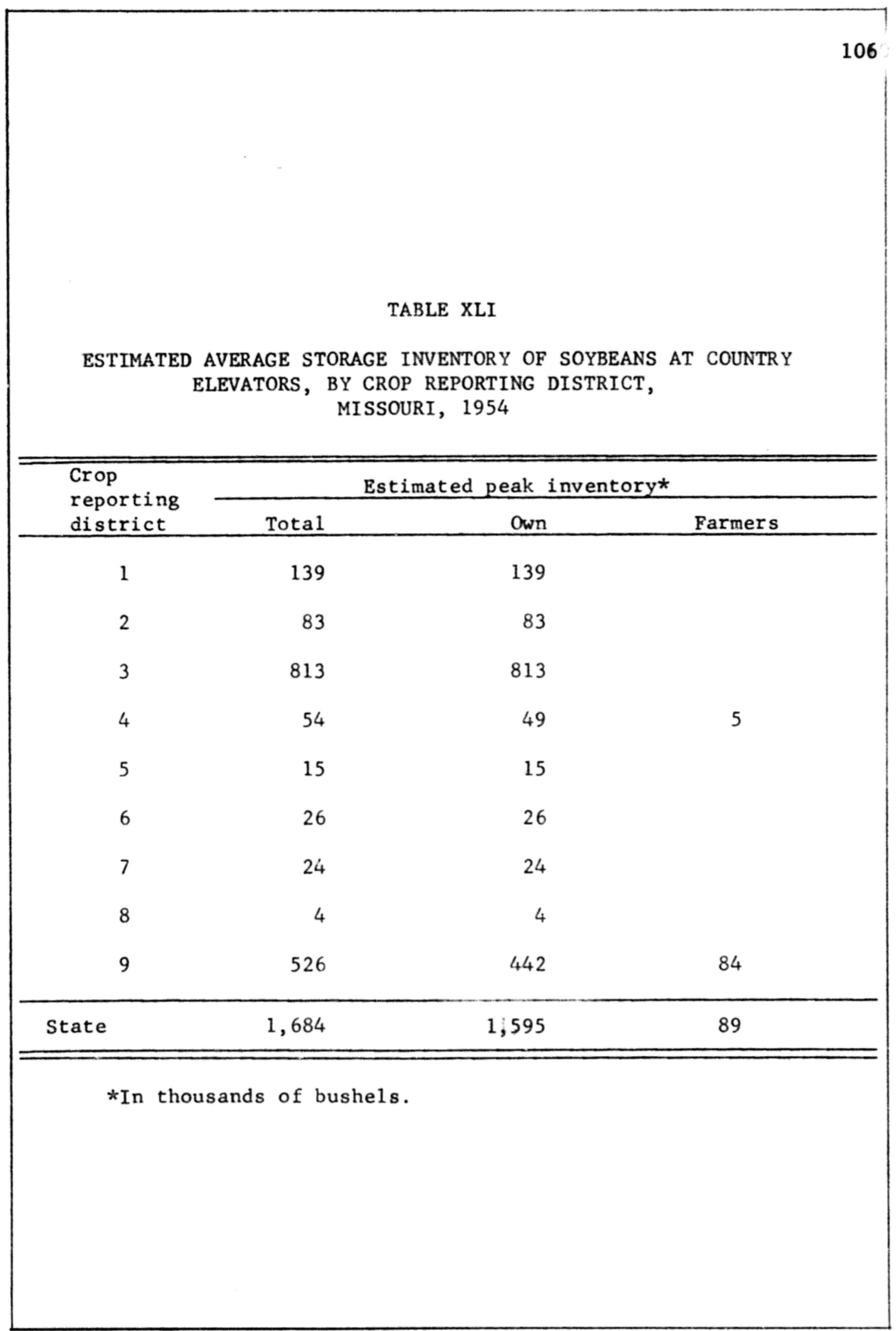


TABLE XLII

ESTIMATED AVERAGE STORAGE INVENTORY OF OATS, BARLEY, AND GRAIN SORGHUM AT COUNTRY ELEVATORS, BY CROP REPORTING

DISTRICT, MISSOURI, 1954

\begin{tabular}{|c|c|c|c|c|c|c|}
\hline \multirow{2}{*}{$\begin{array}{l}\text { Crop } \\
\text { reporting } \\
\text { district }\end{array}$} & \multicolumn{6}{|c|}{ Estimated peak inventory* } \\
\hline & Total & Own & Total & Own & Total & Own \\
\hline & \multicolumn{2}{|c|}{ Oats } & \multicolumn{2}{|c|}{ Barley } & \multicolumn{2}{|c|}{ Grain Sorghum } \\
\hline 1 & 128 & 128 & 17 & 17 & 1 & 1 \\
\hline 2 & 34 & 34 & & & & \\
\hline 3 & 201 & 201 & 5 & 5 & & \\
\hline 4 & 93 & 93 & 34 & 34 & 20 & 20 \\
\hline 5 & 74 & 74 & & & & \\
\hline 6 & 90 & 90 & 32 & 32 & & \\
\hline 7 & 169 & 169 & 77 & 77 & 58 & 58 \\
\hline 8 & 13 & 13 & 4 & 4 & & \\
\hline State & 802 & 802 & 169 & 169 & 79 & 79 \\
\hline
\end{tabular}

*In thousands of bushels.

Note: These grains were all stored as own inventory. 
TABLE XLIII

ESTIMATED SHIPMENT* OF WHEAT FROM COUNTRY ELEVATORS TO ALL MARKETS BY TYPE CARRIER, BY CROP REPORTING DISTRICT, MISSOURI, 1954

\begin{tabular}{|c|c|c|c|c|c|}
\hline \multirow{2}{*}{$\begin{array}{l}\text { Crop } \\
\text { reporting } \\
\text { district }\end{array}$} & \multicolumn{2}{|c|}{ Estimated } & \multirow{2}{*}{$\begin{array}{l}\text { Per cent } \\
\text { shipped by } \\
\text { rail }\end{array}$} & \multirow{2}{*}{$\begin{array}{l}\text { Estimated volume } \\
\text { shipped } \\
\text { by truck }\end{array}$} & \multirow{2}{*}{$\begin{array}{l}\text { Per cent } \\
\text { shipped } \\
\text { by truck }\end{array}$} \\
\hline & $\begin{array}{l}\text { Total } \\
\text { shipments }\end{array}$ & $\begin{array}{l}\text { Volume shipped } \\
\text { by rail }\end{array}$ & & & \\
\hline 1 & 4,159 & 4,159 & 100.00 & & \\
\hline 2 & 1,686 & 1,686 & 100.00 & & \\
\hline 3 & 2,994 & 2,984 & 99.67 & 10 & .33 \\
\hline 4 & 4,492 & 3,680 & 81.92 & 812 & 18.08 \\
\hline 5 & 1,691 & 1,533 & 90.66 & 158 & 9.34 \\
\hline 6 & 4,121 & 3,115 & 75.59 & 1,006 & 24.41 \\
\hline 7 & 4,765 & 4,523 & 94.92 & 242 & 5.08 \\
\hline 8 & 486 & 82 & 16.87 & 404 & 83.13 \\
\hline 9 & 1,932 & 1,753 & 90.73 & 179 & 9.27 \\
\hline state & 26,326 & 23,515 & 89.32 & 2,811 & 10.68 \\
\hline
\end{tabular}

*In thousands of bushels. 
TABLE XLIV

ESTIMATED SHIPMENT* OF SOYBEANS FROM COUNTRY ELEVATORS TO ALL MARKETS BY TYPE CARRIER, BY CROP REPORTING DISTRICT, MISSOURI, 1954

\begin{tabular}{|c|c|c|c|c|c|}
\hline \multirow{2}{*}{$\begin{array}{l}\text { Crop } \\
\text { reporting } \\
\text { district }\end{array}$} & \multicolumn{2}{|c|}{ Estimated } & \multirow{2}{*}{$\begin{array}{l}\text { Per cent } \\
\text { shipped by } \\
\text { rail }\end{array}$} & \multirow{2}{*}{$\begin{array}{l}\text { Estimated volume } \\
\text { shipped } \\
\text { by truck }\end{array}$} & \multirow{2}{*}{$\begin{array}{l}\text { Per cent } \\
\text { shipped } \\
\text { by truck }\end{array}$} \\
\hline & $\begin{array}{l}\text { Total } \\
\text { shipments }\end{array}$ & $\begin{array}{l}\text { Volume shipped } \\
\text { by rail }\end{array}$ & & & \\
\hline 1 & 2,319 & 2,203 & 95.00 & 116 & 5.00 \\
\hline 2 & 4,960 & 4,960 & 100.00 & & \\
\hline 3 & 7,061 & 5,370 & 76.05 & 1,691 & 23.95 \\
\hline 4 & 1,176 & 900 & 76.53 & 276 & 23.47 \\
\hline 5 & 764 & 764 & 100.00 & & \\
\hline 6 & 632 & 593 & 93.83 & 39 & 6.17 \\
\hline 7 & 306 & 306 & 100.00 & & \\
\hline 8 & 39 & & & 39 & 100.00 \\
\hline 9 & 4,354 & 3,296 & 75.70 & 1,058 & 24.30 \\
\hline State & 21,611 & 18,392 & 85.10 & 3,219 & 14.90 \\
\hline
\end{tabular}

*In thousands of bushels. 
TABLE XLV

ESTIMATED SHIPMENTS* OF CORN FROM COUNTRY ELEVATORS TO ALL MARKETS BY TYPE CARRIER, BY CROP REPORTING DISTRICT, MISSOURI, 1954

\begin{tabular}{|c|c|c|c|c|c|}
\hline \multirow{2}{*}{$\begin{array}{l}\text { Crop } \\
\text { reporting } \\
\text { district }\end{array}$} & \multicolumn{2}{|c|}{ Estimated } & \multirow{2}{*}{$\begin{array}{l}\text { Per cent } \\
\text { shipped by } \\
\text { rail }\end{array}$} & \multirow{2}{*}{$\begin{array}{l}\text { Estimated volume } \\
\text { shipped } \\
\text { by truck }\end{array}$} & \multirow{2}{*}{$\begin{array}{l}\text { Per cent } \\
\text { shipped } \\
\text { by truck }\end{array}$} \\
\hline & $\begin{array}{l}\text { Total } \\
\text { shipments }\end{array}$ & $\begin{array}{l}\text { Volume shipped } \\
\text { by rail }\end{array}$ & & & \\
\hline 1 & 4,559 & 1,288 & 28.25 & 3,271 & 71.75 \\
\hline 2 & 696 & 373 & 53.59 & 323 & 46.41 \\
\hline 3 & 368 & 294 & 79.89 & 74 & 20.11 \\
\hline 4 & 615 & 148 & 24.07 & 467 & 75.93 \\
\hline 6 & 26 & 26 & 100.00 & & \\
\hline 7 & 121 & 73 & 60.33 & 48 & 39.67 \\
\hline 8 & 215 & & & 215 & 100.00 \\
\hline 9 & 3,623 & 2,755 & 76.04 & 868 & 23.96 \\
\hline State & 10,223 & 4,957 & 48.49 & 5,266 & 51.51 \\
\hline
\end{tabular}

*In thousands of bushels. 
TABLE XLVI

ESTIMATED SHIPMENTS* OF OATS FROM COUNTRY ELEVATORS TO ALL MARKETS BY TYPE CARRIER, BY CROP REPORTING DISTRICT, MISSOURI, 1954

\begin{tabular}{|c|c|c|c|c|c|}
\hline \multirow{2}{*}{$\begin{array}{l}\text { Crop } \\
\text { reporting } \\
\text { district }\end{array}$} & \multicolumn{2}{|c|}{ Estimated } & \multirow{2}{*}{$\begin{array}{l}\text { Per cent } \\
\text { shipped by } \\
\text { rail }\end{array}$} & \multirow{2}{*}{$\begin{array}{l}\text { Estimated volume } \\
\text { shipped } \\
\text { by truck }\end{array}$} & \multirow{2}{*}{$\begin{array}{l}\text { Per cent } \\
\text { shipped } \\
\text { by truck }\end{array}$} \\
\hline & $\begin{array}{l}\text { Total } \\
\text { shipments }\end{array}$ & $\begin{array}{l}\text { Volume shipped } \\
\text { by rail }\end{array}$ & & & \\
\hline 1 & 17 & & & 17 & 100.00 \\
\hline 2 & 10 & 5 & 50.00 & 5 & 50.00 \\
\hline 3 & 466 & 24 & 5.15 & 442 & 94.85 \\
\hline 4 & 1,033 & 197 & 19.07 & 836 & 80.93 \\
\hline 5 & 49 & & & 49 & 100.00 \\
\hline 7 & 111 & 72 & 64.86 & 39 & 35.14 \\
\hline 9 & 112 & 112 & 100.00 & & \\
\hline State & 1,798 & 410 & 22.80 & 1,388 & 77.20 \\
\hline
\end{tabular}

*In thousands of bushels. 
TABLE XLVII

ESTIMATED SHIPMENT* OF BARLEY AND GRAIN SORGHUM FROM COUNTRY ELEVATORS TO ALL MARKETS BY TYPE CARRIER, BY CROP REPORTING DISTRICT, MISSOURI, 1954

\begin{tabular}{|c|c|c|c|c|c|}
\hline \multirow{2}{*}{$\begin{array}{l}\text { Crop } \\
\text { reporting } \\
\text { district }\end{array}$} & \multicolumn{2}{|c|}{ Estimated } & \multirow{2}{*}{$\begin{array}{l}\text { Per cent } \\
\text { shipped by } \\
\text { rail }\end{array}$} & \multirow{2}{*}{$\begin{array}{l}\text { Estimated volume } \\
\text { shipped } \\
\text { by truck }\end{array}$} & \multirow{2}{*}{$\begin{array}{l}\text { Per cent } \\
\text { shipped } \\
\text { by truck }\end{array}$} \\
\hline & $\begin{array}{l}\text { Tota1 } \\
\text { shipments }\end{array}$ & $\begin{array}{l}\text { Volume shipped } \\
\text { by rail }\end{array}$ & & & \\
\hline \multicolumn{6}{|c|}{ Barley } \\
\hline 4 & 103 & & & 103 & 100.00 \\
\hline 9 & 28 & & & 28 & 100.00 \\
\hline State & 131 & & & 131 & 100.00 \\
\hline \multicolumn{6}{|c|}{ Grain Sorghum } \\
\hline 2 & 139 & 4 & 2.88 & 135 & 97.12 \\
\hline 4 & 177 & & & 177 & 100.00 \\
\hline 5 & 99 & 99 & 100.00 & & \\
\hline State & 415 & 103 & 24.82 & 312 & 75.18 \\
\hline
\end{tabular}

*In thousands of bushels. 
University Libraries

University of Missouri

Digitization Information for Theses and Dissertations project. Scanned from microfilm; no subsequent editing done.

Local identifier

Source information

Identifier

Format

Content type

Notes

Capture information

Date captured

Scanner manufacturer/model ScanPro 3000 /e-ImageData

Scanning software

Optical resolution

Compression

Color settings

File types

Notes

Derivatives - Access copy
Microfilm reel\# T1958-59-T1958-70

Microfilm

Text

2019

PowerScan $3000(\mathrm{TM})$ V5.341

$600 \mathrm{dpi}$

LZW

bitonal

tiff

Scanned from microfilm; no editing done.
Editing software

Resolution

Color

File types

Notes
Photoshop

600 dpi

grayscale

pdf

Converted from tiff to pdf using Adobe Acrobat Pro DC. 